Portland State University

PDXScholar

5-1976

\title{
Specialized Out-of-Home Care Project: An Outcome Study
}

\author{
Carol Teresa Arden \\ Portland State University \\ Bonnie Jean Braeutigam \\ Portland State University \\ Dennis Schilling \\ Portland State University \\ Charlotte Mary Wellman \\ Portland State University
}

Follow this and additional works at: https://pdxscholar.library.pdx.edu/open_access_etds

Part of the Social Work Commons

Let us know how access to this document benefits you.

\section{Recommended Citation}

Arden, Carol Teresa; Braeutigam, Bonnie Jean; Schilling, Dennis; and Wellman, Charlotte Mary, "Specialized Out-of-Home Care Project: An Outcome Study" (1976). Dissertations and Theses. Paper 2137.

https://doi.org/10.15760/etd.2135

This Thesis is brought to you for free and open access. It has been accepted for inclusion in Dissertations and Theses by an authorized administrator of PDXScholar. Please contact us if we can make this document more accessible: pdxscholar@pdx.edu. 
SPECIALIZED OUT-OF-HOME CARE PROJECT:

AN OUTCOME STUDY

by

CAROL TERESA ARDEN

BONNIE JEAN BRAEUTIGAM
DENIS SCHILLING

CHARLOTTE MARY WELLMAN

A Research Practicum Submitted in Partial

Fulfillment of the Requirements for

the Degree of

MASTER OF SOCIAL WORK

Portland State University

May, 1976

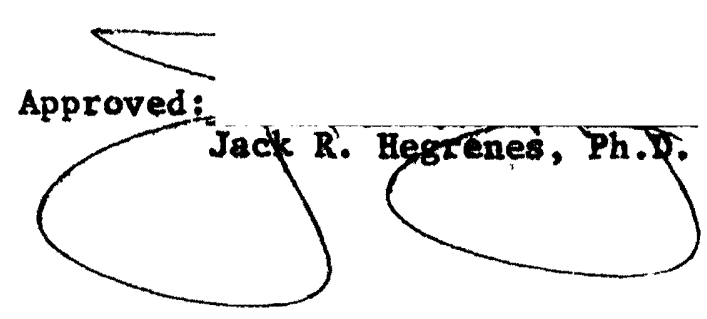




\section{ACKMOWLEDGMENTS}

This research group wishes to express appreciation to the wany wenbers of the social work communtty who assisted in the completfop of this project.

Our special thanks go to the dedicated staff it the Specialized Out-of-Home Care Project for their valuable assistance. The Case Managers from Multnopah County' Case Managenent Corrections Services are also thanked for giving of their time and counsel.

We gratefully dedicate this practicum to the guiding 11 ght of Dr. Jim Heuser, Researcher, Lay Enforcement Counc1l, who although not getțing his bronze statue, does get our genulpe thanks.

Finally, ve wish to thank our advisor, Dr. Jack Hegrenes, Professor, Portland State Unfversity School of Sociel Work. We sipcerely eppreclate the many hours Dr. Hegrenes has contributed to the support and guidance of this practicum project. 
TABLE OF CONTEATS

PAGR

ACKAYULEDGMERTS . . . . . . . . . . . . . . . . 11 LIST OP TABLBS : . . . . . . . . . . . . . . . . . v LIST OF FIGURES . . . . . . . . . . . . . . . . . v111

CHAPTER

I INTRODUCTION . . . . . . . . . . . . . . . 1

II REVIEW OF THE LITERATURB . . . . . . . . . . 6

Delinquency Theorfes and Research . . . . . . 6

Delinquency Prevention ............ 13

III DESGRIPTION OF THE $\triangle G E M C Y$. . . . . . . . . . 24

Agency Descr1ption . . . . . . . . . . 24

Ageney Staffing . . . . . . . . . . . . 26

S.O.H.C. Placement Resources . . . . . . . . 28

Provider Training . . . . . . . . . . 32

Sumary . . . . . . . . . . . . . 33

IV METHODOLOGZ . . . . . . . . . . . . . . . 34

v DESCRIPTION OF CLIBNT POPULATION . • • • . . . . . 37

Descriptive Information on the Client

Population .............. 37

Descriptive Information on the Client's

Fanily .. . . . . . . . . . . . 45

Descriptive Information on the Client's

Identified Problew Areas ............ 47 
CHAPTER

v DESCRIPTION OF CLIENT POPULATION (Cont.) . . . . . . .

Descriptive Information on the Client's 50

Placement Needs

vI FINDINGS . . . . . . . . . . . . . . . 54

DescrIptIve Data Update . . . . . . . . . 54

Placement Data . . . . . . . . . . 54

Cllent's Family . . . . . . . . . . . 57

Client's Identified Problem Areas and Motivation/Capacity for Change . . . . . 59

Comparison of S.O.H.C. and Mon-S.0.H.C. Groups . . . 61

Percentage Compartson of S.O.H.C. and Non-S.0.H.C. Groups ............. 61

Rated Change in Problem Areas of s,o.H.C. Clients.................. 66

Rated Change in Problem Areas of Non-S.0.H.C. clients ............... 69

Statistlcal Analysis . . . . . . . . . . . 74

Summary of Findings . . . . . . . . . . 75

VII CONCLUSIONS AND RECOMRENDATIONS . . . . . . . . . 78

Critlque of the Study ............... 78

Conclusions and Implications . . . . . . . . 80

Recomendations . . . . . . . . . . . 81

SELECTED BIBLIOGRAPHY . . . . . . . . . . . . . . . 82

APPENDIX A . . . . . . . . . . . . . . . . . . 85

APPENDIX B . . . . . . . . . . . . . . . . . . . . 97 


\section{LIST OF TABLES}

TABLE

PAGE

I Flscal Datam-S.0.H.C. (1975) ............. 31

II Source of Referral by C.K.C.S, Offlce .......... 40

III Age Distribution ................. 40

IV Sex Distribution ................. 41

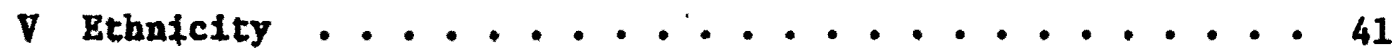

VI Physical or Mental Disability ............ 42

VII Previous Out-of-Home Placements . . . . . . . . . 43

VIII Academic Achievenent . ................ 44

IX Type of Current School Progran . . . . . . . . . 44

X Parental Composition of Client's Fanily. . . . . . . . 45

XI Change Most Heeded by Mother/Father. . . . . . . . . 46

XII Motivation/Capacity to Change by

Kother/Father .............. 46

XIII Problen Arees of Clients . . . . . . . . . . . 48

XIV MotIyation/Capacity to Change by Child . . . . . . . 49

XV Educaflonal Progran Needed . . . . . . . . . . 50

XVI Placement Needs of Client .............. $51 \& 52$

XVII Out-of-Home Placements . . . . . . . . . . 55

XVIII Tine ln Placement ................. 56

XIX TIme Away From Placement . . . . . . . . . . . 57

XX Rated Change in Ch1ld/Parent Relationsh1p . . . . . . 58 
XXI Current Motivation/Capacity to Change

by Mother/Father ............. 58

XXIf Update Date on Problem Areas of Clients ........ 60

XXIII Current Botivation/Capacity to Change

by child ................. 61

XXIV Compartion of Percent Answering Yes to

Problem Areas ................ 6 $64 \& 65$

XXV Update Date on Problem Areas of S.O.H.C.

Clienta ................. 67\&68

XXVI Update Data on Problem Areas of Mon-\$.0.H.C.

Cllents ................ $71 \& 72$

XXYII Mean Motivation/Capacity to Change Scores . . . . . 73

zxvifI Item: Fighting Physically with Peers at

school ................. 86

XXIX Item: Physically Assaultive to Heighbors,

Adults, Peers, Younger Children in Meighbọhood . . 86

XXX Item: No Compliance to Parental Request ........ 87

xxyI Item: Excessive Truancy ............ 87

XXXII Item: Non-production st school .......... 88

xxiII Item: Verbally Antagonistic so As To Continually

Disrupt the Family ............ 88

XXXIV Item: Runaway from Hone .............. 89

xxxv Item: Continually Disruptive to Class at

school ................... 89

xXXVI Item: Theft in Neighborhood Homes and Stores ......99 
XXXVII Item: Theft or Vandalism of Property

within School ................ 90

XXXrII Item: Uees Marifuand .............. 90

XXXIX Iten: Usen Other Drugs ............... 91

Xh. Item: Excessive Use of Alcohol ............. 91

XII Item; Stenling from Family Kembers . . . . . . . . 91

XIII Iten: Refunal to Accept/Perfor Routine

Responsibilities at Hore. . . . . . . . . 91

XIII Item: Kother' KotIvation for Change . . . . . . . 92

XIIV Itea: Mother's Capacity for Change .......... 92

XlV Itea: Father's Motivation for Change . . . . . . . 93

XLVI Iten: Fathnr' Capacity for Change . . . . . . . 93

XIVII Itea: Child's Motipation for Change in Home . . . . . . 94

XIVIII Itew; ChIld's Capac1ty for Change in Howe . . . . . . 94

XIIX Itea: Chlld's KotIvation for Change In School . . . . 95

I. Item: Child' Capacity for Change in School . . . . . 95

II Item: Child' Motivation for Change in the

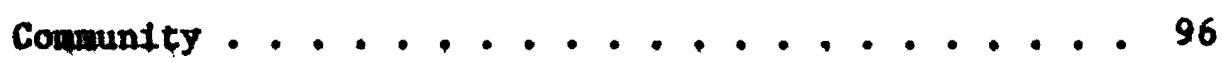

LII Item: Child's Capacity for Change in the

Community . . . . . . . . . . . . . 96 


\section{LIST OF FIGURES}

\section{PIGURB}

RAEE

1. Case Flow Through the Correctlonal syoten. . . . . . . 5

2. Delinquency and Kon-delinquency in Anericap Society. . . 6

3. Flow Chart of Case Hanagenent Referrals to

C.S.D. for Out-of-Home Care, August 1974 . . . . . 27

4. Four-fold fable ................. 37 
CHAPTER I

IATRODUCTION

This research practicum is ap outcone study of the Spectnlized Qut-of-Hone Care project (S,0.H.C.). The project, administered by the Oregon Children's Services Division, was designed to provide altarnative care resources to speciffcally meet the neede of Portland's fuvenile target pffenders, who required out-of-hone care. The juvenile offenders accepted Into the S.O.H.C. project vere between the ages of ten to eight teen, and had been adjudicated for target crimes. The s.o.k.c. project was federally funded for a twenty-nine wonth period beginaing on May 1 , 1974 and extends through september of 1976. This study wi1l Include only the cliepte referred and placed during a one-year perlod, from Jufy 1, 1974 to June 31, 1975. Additional "up-date" Information yas collected In October of 1975. A vartety of alternative care resources were utilized as placements for the client population. Clients were placed in foster fanilies, group hones, day-care settings and residential centers. This practicum was undertaken as a cooperative effort by four M.S.W. students, of Portland State University's School of Social Work, working confolptly with the S.O.H.C.'s project staff in the over-all evelustion of the profect. The purpose of this study was to assess the finpact that services provided by the S.0.H.C. project have had on the target populatlon of juvenile offenders. This introductory chapter provides a brief overviev of the content of the practicum. The following chapters will 
Include: (1) a review of the ilterature on fuvenile delinguency and deIInquency prevention; (2) a description of the agency; (3) a section on the methodology and analysis utilized in this study; (4) a description of the client population; (5) a chapter sumarlzing the findinge; and finally, (6) a chaptẹr discugsing the conclusions and recomendations. A considerable amount has been written in the area of fuvenile deIInquency as well os on the programs designed to prevent delinquency. The review of the 11terature will illustrate nore clearly the complexitien of jovenile delipquency and delinquency prevention programs. Although the majority of the research states that many of the prevention programs have not had a significant impact in reducing juvenile delinquency, new programs continue to be developed with hopes of having the desired fupact. The 8.0.H.C. project 18 such a program whose main thrust has been to provide apeclallzed qut-of-hone care services to youthful target offenders. $\Delta$ complete description of the agency and cllent population will be provided in two of the subsequent chapters. As this study was designed to assese the Impact that pervices have had on the client population, a "before and after" description of the client population will be Included In these chapters. Included in the "before and after" deacription of the cllent population will be auch Items as behavioral problems of clients, the cllent's motivation and capacity to change as well as the cllent's parent's motivation and capacity to change. These factors w111 be espem clally important in Identifying the impact that service provided by the S.P.H.C. otaff have had on the client population.

The chapter on the methodology will provide a more complete picture of the research design enployed in this study as well as the specifics 
of how the data was collected. The McNemar test of significance w 11 be used in the analysis of the data. The Melemar test for the significance of changes is particularly applicable to the "before and after" deatga used In this atudy In which each client 18 used as his/her oun control and in which mensurement is in the strength of elther a nontual or ordinal scale. Further elaboration of these tests of significance and theif applications will be made in subsequent chapters. The final chaptef will sumarlze the findings and $d$ iscuss the conclustons that will be drawn from this evaluation. 


\section{CHAPTER II}

\section{RBVIEW OR THB IITERATURE}

\section{DELINQUENCX THEORIES AND RBSBARCH}

Hoat people can agree that juvenile delinquency is a problem. However, there is a lack of agreament on what it 18, how much of it there 18, who Is Involved, what causes 1t, and what to do about 1t. Although there has been much discussion and theorfing about juventle delinquency, there seems to be little conclusive research.

This section of the review of the 1iterature focuses on delinquency theories and research. We are greatly Indebted to Don Gibbons and his book Delinquent Behavior, second editlon, in which he exhaustively reviews the state of the art.

To exanine delinquency one must look not only at the act of delinquency itself, but also at the social response to delinquency. Public opinion and the legal, police, and correction systems all influence how delinquency is percelved and handled.

"Juventle delinquency consists of ects or infractions which are prohibited in the statutes of the Individual states. Juvenile delinquents are youths who comnit one or more of these crimes" (Gibbons, 1976).

There are two types of offenses under fuvenile statutes. One type is those offenses that are also 11 legal for adults. The sacond is status offensea; those offenses that would not be criminal if committed by an adult. Examples of status offenses Include running avay, truancy, 
drinking alcohol, breaking curfew, belng beyond parental control, being ungovernable, and incorrigibility. Th1s last type of general catch-all clauge is 1fitted virtually to the United States (GIbbons, 1976). Status offenses have accounted for half of the referrals for girlo to fuvenile courte and one-fifth of the referrals for boys (Periman, 1970).

A youth's Involvement with delinquent behavior may be a soradic, transient expertence, or it can evolve into more serious, repetitive behavlors which may come to the notice of police and court officlals. The officlal delinquency statistics reflect police and court reports. One question ratsed is how much delinquency is not noticed in the officlal reports.

The process juventles go through to become part of the pfficlal statistics is shown below in Figure 1. (Gibbons, 1976).

\section{Offenses}

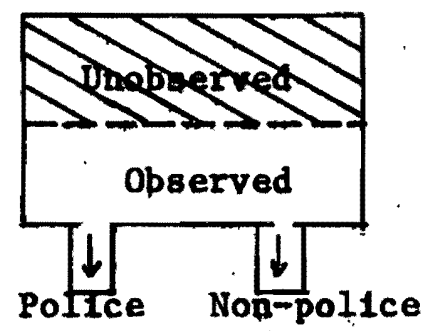

contact referral
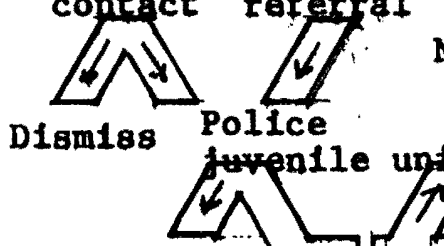

Release or station adjustment

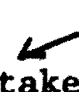
Non-adjudicatory disposition Private ' agency

Intake

hearing

Figure 1. Case Flow Through the Correctlonal System. 
Some delinquency remains unobserved, Estimates vary on how many youths are Involved in unnoticed delinquent acts, but studies, notably those of Short and Nye, and W1111ams and Gold, show that a majority of youth commit at least one delinquent act (Short \& Nye, 1958, W1111ams \&,Gold, 1972). Those who come in contact with pollce are usually involved in pore serious, repetitive offenses (G1bbons, 1976). However, there may be some selective obserying on the part of the police, In the sense that police pay more attention to high crime and low-income areas. Middle and upper clags neighborhoods may have more acts of delinquency that are not observed because of less police coverage (Glbbons, 1976). Gibbons used the followIng diagrap of delinquency and non-delinquency (GIbbons, 1976).

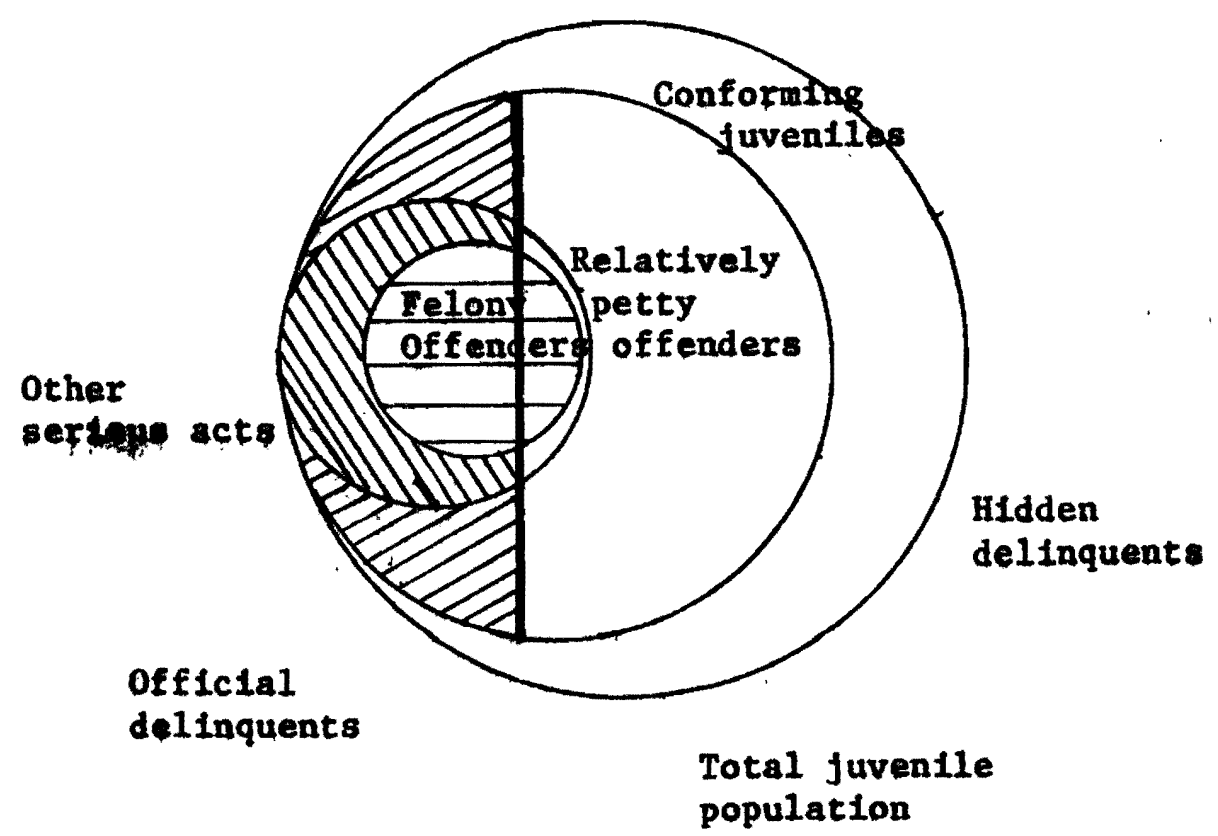

Pigure 2. Delinquency and Nondelinquency in Amertcan Soctety. 
Even after juveniles come in contact with the police, some are disussed with no further contact. These cases the pollce uspally handle Informally with just a warning. FBI statistics for 1973 Indicate that 45.2 percent of apprehended juveniles yere handled this way (ए.s. Dept. of Justice, 1974).

There have been numerous studien on pollce dispositiqn (see Goldman, Terry, Bodfne, KcEachern and Bauzer, Ferd1nand and Luchterhand, and Thornberry). Theif results are not conclualve. In most cases the declding factor in how the cases were handled was the serfoumpess of the offense. The juventle's attitude was also related In the gense that more deferentlal youth tended to receive warning. In some cage racial and econonic factors did Influence the dispostelon, with whites and highex Income groups recefving just varninge. Overall, the atudle reflect - leck of unfformity among pollce departments in how they handle juveniles (G1bbons, 19q76),

Sope dalinquency is of a wore serlous nature. According to IBI statistics, fuvenileg ver responsible for 10.4 percent of the howicides, 19.6. percent of the forctble rapes, 33.7 percent of the robberien, 17.0 percent of the asseults, 53.8 percent of the burglarles, 45.2 percent of the larcentes, and 56.5 percent of the motor vehicle theft for a total of $6,499,864$ arrests excluding traffic offenses (U.S. Dept. of Justice, 1974).

There are two pain approaches to causation theories. One is p8ychological, that is, there is some Internal problem within the delinquent that makes her/hip act that way. This problem can be caused by epvironmental factors such as inadequate parents who give the child a poor self- 
imege. One of the difficulties in testing these theories lies in operationalizing these concepts. The data can also be interpreted in different waya. For example, one of the wain studiea based on the Jences inventory feports that the institutionalized delinquents were more hostile, feft wore isolated, and vere less mature than non-1nstitutionalized youths. However, these feelings could be resulf of the Institutionallantion and Inyolvement in the correctipn ajptem (GIbbons, 1976).

The second approach is based on the societal tructures which can contribute to delinquent behaviar. The paychological theories can, at times, overlap or fit in vith the oclological. Paychological tests reveal delinquents are 1 ans vel1-adjusted than non-delinquents (Gibbons, 1976). This could be in response to the social ingtitutions. One could see the problem of adjugtment as in the youth or in the lnadequacies of the inotitution. Treatwent chofces reflect different types of interpretations.

The soctological theortes are divided Into broad and niddle range theories. Broad theortes look at society as whole in trying to explain delinquency, while widle range theortes deal with a specific area of soctefy or kind of delinquency,

When looking at society as a wole, Merton's anowle theory is ueed to explain causative factors. Hs theory holds that deviance is a response to the unavailability of socially approved routes to success (Gibbons, 1976). This type of broad theory has been applied at a niddle level by Cloward and ohlin (eee below).

Another group of theorists see social disorganization as leading to delinquent behavior. They claim a lack of soctal coordination, a 
lack of relationship bonds, and value clashes between different graups within the society es contributing factors (Gibbons, 1976).

A final theory deals with the lack of soctal control in this culture. HIrschi is the maln proponent of this vies. His etudy ohowed deIInqupnt yputhe being less attached to parents, school, peers and conventional activities (G1bbons, 1976). Relly and PInk applied this to conforming behavior at school and found delinquents lass comitted to and involved in school and extracurricular activities. They did not have as wch to risk in becoming inyolved In delinquent behavior as those students who were more Involved and had wore at stake in the achoof ayeten (Kelly \& Plnk, 1973).

While the more general theorles seem logical, they are difficult to test and apply practically. Lately more theorists deal with "maddle" range theories to explain one part of delinquency. This latter approach does not view delinquents as homogeneous group, but rather as diverse group of youth Involved In different behaviors.

Much effort has been spent on working class and lower class delinquency beginning with the Chicago school in the early 1900's (Gibbons, 1976). Yore recent efforts have been directed towards looking at the Interactlonal effecta of enviromental variables, the delinquent subculture, opportunity structures, and lower-class focal concerns.

Environmental factors have been studied in ordex to match correlations between them and delinquent behavlor. Quinney, Polk and WIIlie looked at delinquency rates in three cities. Econonic deprivation was a major factor in delinquency, with family atability as an important influence (the pore atable the family, the less evidence of delinquency) 
(Gibbons, 1976),

Gang delinquency has been examined through the concept of delin-: quent gubculture. "Subcultures are value patterns and behovtoral aystemp wh1ch are shared by Individual gangs and these precede and persist beyond the life span of any alngle group" (GIbbons, 1975). Albert Cohep's book Deilnquent Boye published In 1955, atimulated a large amount of research. Cohen's argument stated that delinquent subculture support behavior which is non-utilitarian, allefous, and negatiplotic (Cohen, 1955). Lower-clans boys become Involved in the subculture because of shared problem of low self-esteen resulting from being measured by plddle-class standards for which they tere not properly sociallzed (Cohen, 1955). Two criticisms of Cohen's work were rałsed by John Kituse and David Dietrick, and David Bordua. Kituse and Dietrick claimed lowor-class boys do not measure themelves by middle-class standards so would not have such low self-esteem. They also see the gang as less maliclous (Kituse \& Dietrick, 1959). Bordua thought Cohen did not give enough weight to fanily, ethnic, and other social variables (Bordua, 1962),

Richard Cloward and Lloyd Ohltn have beep the maln exponenta of a theory based on opportunity structure.

Our hypothenis can be summarized as follows: The disparity between what lower-class youths are led to want and what 1s actually avallable to then ts the source of a major problem of adjustment. Adolescents who form delinquent subcultures, we suggest, have Internalized an emphasis upon conventional goals. Faced with limptations on legitimate avenues of access to these goals, and unable to revise their aspiratlons downwards they experience intense frustration; the exploration of non-conformist alternatives may be the reault. (Cloward and Ohlin, 1960).

Bordua, as with Cohen, did not see Cloward and Ohlin giving enough weight 
to family, ractal and other varlations among lower-class groups (Bordua, 1962).

According to Walter Miller, delinquency is the product of longestablished, durable traditions of lower-class life such as femalp-headed households. These cause the adolescent male to have anxieties about his sex role. Gang involvement is a way to prove his masculinity. Miller also postulates "focal concerns" which are broad themes of lower-class 11fe. These include avolding entanglements with police, being "tough", belng able to live by one's wits, having excltement, and being autonomous. Theap themes can be lived in the gang experience (Gibbons, 1976). Gibbons summed up the vast research done on gang behalor. The opportunity stfucture theory has held up best under research, but the theory does not take enough account of intervening variables, ouch as fam1ly patterns. Over-all, the evfdence seems to indicate there are several reasons for gang involvenent guch as soctal status concerns, deprivatfons of lower-class Iffe, protection from other boys, etc. However, one cannot generallze about all gangs (Gibbons, 1976).

Middle-class delinquency has not received the attention lower-class has unt 11 recently. The main theory revolves around the concept of a "youth culture" which has shared concepts of values, behavfors, and characteristics different than those of the prevaling adult culture. This culture can lead youth into delinquent behavior. The culture is based on a pleasure principle, emphasizing Immedlate gratification of "hedonistic" needs. Cohen, along with Ralph England, attributes this to the lack of functional roles for the adolescent (Vaz, 1967). Cohen also discusses "the erosion of adult control" over the adolescent (Cohen, 1975). Joseph 
Scott and Edmund Vaz see the behavior exaggerations of activities encouraged by adulte (Vax, 1967). Bichard Placks viers the youth culture as a ayptow of crisis as established Institutions resist the change brought on by technological advancepent. Youth, less astablished in the social order, are often the f1ret to repond to the crifif (Placks, 1971). Other proposed theoftes atate adolescents engage In delinquent behavior becaupe of anxiety over magculine Identity, lack of conattengr. to school, job and other adult roles, tension over change due to upward wobllity, and the spread of lower-class values among middle-class youths (G1bbons, 1976).

There is 11ttle reaearch to support these theor1es. One study by Wye points to fanily instabllity, parental rejection, and lack of commitment to church as all being correlated to delinquency. Adolescents who came frow large fomilies or fantlley that had changed soclo-economic class were also pore likely to be delinquent (Nye; 1958). A study by Gerald Pine supports the Idea of lack of commitmept to adult reles as being Involved in delinquency (Pine, 1955), However, more research needs to be done before any conclusive statenent can be made.

Very little attention has been paid to the delinquent behavior of young women. Host studies have Involved oply ale adolescents. Only a minority of court referrals Involve delinquent g1rle, but they seem to be treated differently. ".. various actions taken against fenale juveniles are haraher than those directed at males in comparable forns of Flobehavior. . the juvenile justlce gyetem operates in vays that are concerned 108 about the protection of the rights of youthful females than with the Interests and values of other groups" (G1bbons, 1976). 
Meda Chesney-Lind states the authoritles are mast likely to take actions againgt young vomen who are suspected of being involved in sexual behavior or in danger of becoming involved in eaxual experimentation. The sane action is not taken agalnst males (Chesney-Iind, 1974).

The theories on fexale delinquency emphesize the parent-child relat lonship and the different treatment of boye and girls in the home regarding the amount of freedon. The fact that young girls are often more closely supervieed than boys can create family copflict. Dellnquent gifls are usuelly thought to be responding to some kind of family tension. This was 11lustrated in studies on female runaways who were trying to deal with an 1ntolerable home stuation (Gibbons, 1975). A study on lower-cless femele delinquents showed 80 percent came from broken homes (Ba11 and Logan, 1960). Again, enough research has not been done to make any conclusive statement. With the slowly changing sex roles, changes in female delinquency and soclety's response to it any also occur. In sumary, very little can conclusively be sald about juvenile delinquency. Delinquent behaviors take a vide variety of forws with many diverse and complex aptecedents. At best, one can conclude that family relationships, sociomeconomic factors, comitnent to and opportunity to fill adult roles all interact vith delinquent behavior.

\section{DELINQUENCY PREVENTION}

The second part of the literature review will focus on delinquency prevention. The aress to be covered in this segaent are as follows: 1.) a conceptual framework of delinquency prevention, 2.) a survey of the types of delinquency prevention programs, 3.) a review of the evalu- 
ative studies of delinquency prevention programs, and 4.) a discussion of the new concepts for delinquency prevention reform.

A starting point in reviewing delinquency prevention, a definition will be put forth to provide starting base. Basically, prevention denotes the ability to plan and implement mesures prior to events that are likely to occur. Delinquency prevention is then the planning and implemepting of measures prior to the delinqueat acts themselves. Fen could argue against the merits of planning and implementing measures to prevent delfiquency. However, a range of solutions to the delinquency isaue have been offered and many Interventions have been tried with 1Ittle success in steming the tide of delinquent behavior (Mech, 1975). In 1970, approximgtely one milion youths between the ages of ten to seventeen were referred to the Hatton's fuventle courts and an additional. three willion youths experienced police contact during that year. ProJection for 1975 ouggest that nearly thirteen w111ion youthe and their parents pill be referred to juventle court. Based on a conservative cost estimate of $\$ 100$ per youth referred to the juvenile justice system In 1970, the anpual price tag is in the vicinity of one-hundred nillion dollars (Gemignani, 1972).

The inability of traditional delinquency prevention programs to significantly effect the rise in delinquency has engendered an Increasing amount of public criticism. In response to public criticism and deficlencles in the delinquency prevention prograps, a Task Force on Juvenfle Delinquency was established by the President's Comission on Law Enforcenent and Administration of Justice. Included in their final report was the following indictwent: ". . the great hopes originally held for 
the fuventle court have not been fulfilled. It has not aucceeded in rehabilitating delinquent youth, In reducing or even steming the tide of juyentle criminality, or in bringing justice and compession to the child offender" (President's Combsaton on Law Enforcement, 1967).

The Comnisefon Report re-emphasized the need to develop non-legal alternatives for Juveptles. The Report focused attention on developing non-judicial fesources for juveniles who pose "no immediste threat to public safety" and discouraged the practice of direct referral to court on "minor" delinquents or of "non-criminal law-violating" juveniles. The fundamental goal degignated by the Comisaton Report the handling of youth outside the juvenile justice system, recomending that non-judiclal alternatives be created by "comunity efforts" and that services "be local" (President' Comission on Law Enforcenent, 1967).

There are basically three perspective in vieuing delinquency prevention. The first vlewpoint is one that includes all youth as a target for delinquency prevention programs. Under thi perspective, prevention Is synonywous with promoting a healthy development of all youth. Delinquency is then seen as a function of institutional weaknesses, as poor family relations, prejudice and discrimination agalnst minority groups, etc. This view holds that youth are influenced by their soclal environments and Institutions which predispose so-called delinquent behavior (Mech, 1975).

The second perspective includes potential delinquents or youth who appear to be on the road to delinquency. The focus of prevention programs would be on identffying such youth and forestalling their further, more serious, delinquent acts. This view emphasizes direct service in- 
tervention with youth, rather than improved environmental and/or institutlonal conditlone (Mech. 1975).

The third prevention viewpoint focuses on Juventle offenders and cuphasizes reducing patterns of recidivism and of lessening the probab111ty that youth 111 comit eerlous offenses. ThIs perapective centers on reaching Juventle offenders with the afm of cuteing shopt delinquent behavior and helping youth already in difficulty from comalting wore serious offenses. Th1s perspective does not emphesize preventing the onset of delinquency and is the naxrowest of the three views of delinquency prevention (Mech, 1975).

The following paragraph will review delinquency prevention programs that have been implenented in the past. Much of the content of the revtey to synthesis of a larger review done by Bdmund yech in 1975. Mech diftdes delinquency prevention programs tato apall-scale and largepeale interveptions.

8mal1-scale Interventions are essentially programs that focus on Indfolduals and sanll groups. Contemporary approaches to delinquency prevẹtion have characteristically directed their efforts towarda individuals and sapll groups, Mech breaks down small-scale interventions Into the following program categories: 1.) outreach, 2.) Individual services, 3.) group services, 4.) vork experiences, and 5.) behavior modification (Hech, 1975).

There are several underlying assumptions subsuned in these prograns focusing op Individuals and swall groups. The main assumption is that deviancy is the repult of Intra-psychic malfunctioning which requires some form of individual therapy to rectify this walfunction. Much of 
the practice 1iterature emphasizes the personality structure of delinquente which is reflected in a statement by Hymen Grosebard, "It is ay belief that all delinquents, regerdleas of the type of disturbance, have certain comon peychological processes that operate vertically in their history and horlzontally in their functioning" (Grosabard, 1962). Grosebard goes on further to stete that delinquents have inefficlent ego mechaniems and are characterfaed by lessened abllity to tolerate frustration, to control responses to stimuli, or to postpone gratification. The intervention response to this paycho-dynanic analysis has a theraputic orfentattop, advocating paychotherapy, casework, counseling, and guidance with individuals and amall groups.

Edound Kech gelected five atudteq far each approach in his review af the amall-acale Intervention of delinquency prevention programs. The first approach fincluded the programp propiding outreach nervices. The aims of auch program lacluded; 1.) to provide direct services to youth and refer to other agenctes when pecesgary, 2.) to ald youth in finding socially acceptable Iffe styles, 3.) to devalop comunity interest in youth, and 4.) to provide services to fantlies unable to segk help (Mipch, 1975).

of the five programs chosen ( $9.8 .$, Nelghborhood Youth Assoctation, Los Angeles; Henry Street Settlement, New York; New York C1ty Youth Board, etc.) gnly three studies reported results, with two suggesting a positive outcome and one reporting no significant difference. Much of the evaluative Information was subjective with a generel lack of scientific methodology throughout the studies.

In the area of Individual services, the program aims included; 
1.) to ald youth with problems, 2.) to assist youth with school, lefsure time, and employment, and 3.) to provide youth with B1g Brothers, educational opportunfties, recreational activities, and fobs. of the five programs chosen for comparison of outcome evaluations (e.g., Denver Boy's Club, L.A. Dellnquency Control Project, Greater Kansan Cqty Mental Health Foundation, etc, ) only two reported significant resulț, one vas not significant, and the remaining two made no evaluation (Mech, 1975).

In the are of group services, the program alms Included: 1.) to aid parents in resolving youth' problems, 2.) to provide casework to disadvantaged familles, and 3.) to strengthen the fapily unit and aid youth in creating wholesome milieu. of the programs selected (e.g., Metropolitan Youth Compission, St. Louls; United Neighborhood Houses of Sew York; Judge Baker Guldance Center, Boston, etc.) only one reported an evaluation which had algnificant results, but was largely impression1stic. The other four reported to evaluative studies whatsopver (Mech, 1975).

In the aree of work experience programs, the program alms fincluded: 1.) to provide a training guldance program, 2.) to reach youth in financlal need, 3.) to rehabilitate problem youth through a work program, and 4.) to keep youth in school through a work-8tudy program. Of the programs reviewed for this outcome comparison (e.g., Job Opgrading Project, North Rlchmond, Ca.; Youth Conservation Corps, PhIladelphia; Job Placement and Work Therapy Program, Cincinnat1, etc.) all reported a significant impact on youth or claimed positive results (Mech, 1975).

In the area of Behavior Modification Programs, the program aim Included: 1.) to train parents in the techniques of behavior manegement 
to enable then to control youth, 2.) to modify pre-delinquent youth's behavfor in the natural home setting, and 3.) to devise and evaluate mnhods of reducing pre-delinquent and delinquent behaviors in yputh. of the programs selected in this revtew (e.g., Oregen Research Institute; Southwept Indian Youth Center, Tucson; Untversity of Ransas "Achievement Place", ptc.) all reported universally significant outcomes. Algo, the methodology used in evaluating these behavior modification prograp was scientifically valldatad with the subsequent reoults being more objective than the previous studiea (Mech; 1975).

In sumarizing the amall-gcale intervention program, very little conclueive evaluative Information is avaluable to validate the effectiveness of such programs. However, the programs under the behavior modification approach were the wost auccessful in validating their effectiveness as thatr research methodology was by far the most sclentific. This sumpary Information does strongly suggest the need for nore effective research in evaluating delinquency prevention programs.

The other large category of delinquency prevention programs includes the large-scale interventions. Large-scale interventions are interventions that derive from broad social analyses of conditions that require change. There are basically three forms of these types of interventions: 1.) area improvement efforts, 2.) coordination of services, and 3.) recreational approaches (Hech, 1975). The underlying assumptions of large-scale interventions are as follows: 1.) social conditlons Increase the likelihood that youth will become delinquent, 2.) the environment of a particular comantity is viewed as insufficient to counteract the allenation of its youth, and 
3.) effective delinquency reduction programs must go beyond the individual's psychlc deficienctes.

In area intervention programs, the progran aims included: 1.) to develop effective methods of Inducing local residents to commit thenselves to preventing delinquency, 2.) to Improve services to clients in public bureaucracies, 3.) to develop aelf-organization and to encourage disadventaged residepts to participate in public decisions influencing their lives, and 4.) to develop local comantities so that residents could become the chlef force for changing the character of their neighborhoods (Mech, 1975).

Examples of specific area intervention programs Include Chicago Ares Projact; Mobilization for Youth Profect, Syracuse; Crusade for Opportunity and Unfted Planning Organization, etc. The final assessments of the above prograns were heavily qualitative in qature, 1.e., Iftcle "hard" dat yas collected to support the evaluations. However, sumary discusplons of these programs pointed out that "natural" citizen Involvement, at a local level to support delinquency prevention efforts, was created by the efforts of these area intervention programs.

Apother large-acale intervention approach is to prevent delinquency by coordingting coppuntty gervices. Th1s approach recognizes the difficulty encountered by established community services due to having taken separate paths and lecking the coordination necessary to effectively Impact on compunttles. The program aims of these coordination approaches Included: 1.) to coordinate services offered to youth in communities, 2.) to locate youngsters in need and secure services for then, and 3.) to enhance cooperation between existing agencies in a coumunity that 
provides social services. Examples of specific prograns designed to coordinate services Include Passalc Children's Bureau, New Jerpey; New York CIty Youth Board; and MInneapolis South Central Youth Profect. Ho formal evaluations of the effectiveness of these program ware undertaken although ties between communty agencies were reported as betng trengthened.

As was stated earlier in the summary of the gmall-scale Intervention programs, concerning the lack of concrete evaluative Information, the rasults of large-scale intervention studies fail to offer such information about the effectiveness of these programs as well (Mech, 1975).

Other authors have come to similar conclusions about the over-all Ineffectiveness of delinquency prevention programs. Charles Logan recently concluded evaluation research in delinquency and states, "He find that as far as the survey and review has been able to deterpine, there Is not yet one single study of correctional or preventepive effectiveness that will satisfy the most minimal standard of scientific design." Some of the methodological weaknesses that Logan cited were as follows: program or techniques not adequately defined; techniques were generally not capable of being repeated; many lacked a control group or assignment of cases to the control group was often not random; and finally, follow-up In the community was not present (Logan, 1972).

This completes the review of the literature on past and present delinquency prevention programs. Before closing though, a brief review of the new concepts in delinquency prevention will be included in the following paragraphs.

To begin with, delinquency prevention needs to be re-defiped. 
Lamar Bnpey aptly defined prevention as follows: "Prevention any be defined as the process by which young people acquire a legitimate identity, a atake in conformity, and a respect for the juvenile justice systen (Pfak and White, 1973). Empey emphasizes the need to offer youth wore opportunitfes to experience a legltimate role identity. This premise is the basis of the following new concepts in delinquency prevention, diverston and notrallzatton.

Diversion is the process of diverting youth engaging in status offenses (truancy, neglect, gambling, curfer violations, etc.) out of the juvenile justlce system. This process would Involve creation of nonlegal organizations so that intervention could be undertaken in the coramunity setting. In this way, the adolescent would experience the least posalple dieruption to her/his wovement through the priary socializing Institutions in which legitimate identitles are forged. The act of diversion would open the way for the development of a variety of social action organizations that would serve to involve the communtity in the mapagement of their own problems. Diversion of youth frop the juventle justice system would lower the possibility of Individuals becoping $1 \mathrm{n}-$ volved in secondary deviance. The underlying assumption is that the leapt contact wth otigmatizing ingtitutions, the better (Pink and White, 1973).

Normalization is the process where the status behavior is responded to as acts pore characteristic of adolescence In general, rather than an Indication of efther Individual pathological problems or a subsequent criminal career. The major thrust of this position is that youth should not be routinely thrust inte the justice system. Involved in the inter- 
vention strategy of normalization is the presence of alternative structures such as community-based, non-professional organizations to intervene, if necessery. The following considerations must be noticed in such a strategy: 1.) alternate structures need to be comunity specific, 1.e., designed to fit the need of that community, 2.) they must be fully legitimated by the commity 19 which they functiop, 3.) they must be coordinated vith the existing juvenile justice oyatem, and 4.) compuntty-bsaed programa need to be planped and developed 80 as to avold the trap of labeling "rotten" youth, thereby negating the notion of diverston and normalization (PInk and White, 1973).

In sumarizing this review of the literature on delinquency and deIInquency prevention programs, it is quite apparent how complex these areas are. The first section of this review sumar1zes delinquency ftself, police response to delinquency, and the different causation theorles of delinquency. Ope issue this area of the review aptly points out is how difficult it has been for researchers in the field to agree upop a conceptual model of delinquency. This lack of agreenent is also apparent 10 the review of delinquency prevention programs. One theme that is consistent throughout the literature is how necessary it is to develop research methodologies which wi11 provide more accurate evaluative inforwat fon about programs that are developed. Also, it is important and necessary for people working in this fleld to learn from the wistakes of previọs approaches and to develop new strategles which will not replicate these mistakes. 
DESCRIPTION OP THE AGENCY

The Specialized Out-of-Hone Care Profect (S.O.H.C.) Is delinquency prevention program wich deals only vith furentle offenders. It gael Is to prevent re-occurrence of the delinquent behavior rather than the first occurrence of that behavior as in broader based prevention prograns. The s.o.H.C. profect is a and1-scale intervention program focuplag on individual change as opposed to institutional change. The approach is sinilar to Bdwund Mech' conception of a program providing individunl services by alding youth with perponel problems, school, we of leisure tIme, and eaployment. (Mech, 1975). However, the project goes beyond this by providing an alternative living situation. Thie involves enviromental manipulation and an overlapping soctological parspective regarding Influence of societal instftutfons. In addition, the project does provide some group services with fanilies, but this has not been the wajor thrust of the program. The following chapter provides a more detalled description of the s.0.H.C. project, staffing patterns, placement resources, and training given to providers.

\section{AGENCY DESCRIPTION}

The Specialized Out-of-Home Care Project (S.0.H.C.) is administered by the Children's Services Division (C.S.D.) Region 1, Multnomah County, and is federally funded for a twenty-nine (29) wonth pertod by 
the Law Enforcement Administration Agency (L.E.A.A.). This funding period began May 1, 1974 and extends through September 1976. The man goal of the Speciallzed Out-of-Home Care Project is to provide alternate care resources to epeciflcally meet the needs of Portland juvenile target offenders requiring out-of-bome care (Jenkins, 1974). All of the offenders accepted, Into the S.O.H.C. Project are between the age of pan eighteen, and have been adjudicated for target crimes. Target crimes are generally deflned as stranger-to-stranger street crimes or burglary. More specifically, they include robbery, veapon assault, honiclde, rape, and burglary as shown by polfce arrests, excluding Incldents where acquaintance or interpersonal relationship was a precipitating factor in the offense (Jenkins, 1974). Bach of these target crimes would be considered a felony if the offender was of adult statua.

Operating cooperatively with Multnomah County's Case Mangement Corrections Services (C.M.C.S.), the S.0.H.C. Project's atraion is to provide serviçes to approximately one-hundred-fifty (150) Juveniles with an average placement perfod of $81 x$ to nine months. These juyentles have been referred to C.S.D. by C.M.C.S. for out-of-home care. During the 1975 flscal year, C.M.C.S. received 378 referrals within Multnowah County. Of these referrals one-hundred-elghty-one (181) were seen by C.M.C.S. an appropriate referral for the S.0.H.C. Project. During the 1975 fiscal year, the S.O.H.C. Project provided a range of services to these one-hundred-eighty-one (181) C.M.C.S. referrals, the majority of whom vere male. Eighty-five (85) adolescents were placed in S.0.H.C. developed placemepts, and twenty-81x (26) adolescents were channeled into other resources, 1.e., residential treatment facllities, regular foster 
care, child care centers, etc. Terminations totaled 38 during the 1975 fiscal year (Tate, 1975, b.). (Please refer to Flgure 3. for a visual concept of the process Involved when an adolescent coanits a target offense and enters the S.0.H.C. Project) (Tate, 1975, a.).

The primary objectives of the S.O.H.C. Project are to:

1). Iq offer a central Intake point for all C.M.C.S. out-of-hame cẹre referrals.

2). To locate ox develop out-of-home care resources destgned to meet the apecific needs of referred youth.

3). To model case planning that is both goal-apectific and timelimited (the average placement is six to nine monthe). Also Important is S.0.H.C. monttoring of Individual case plans by coordinating the various actorg involved in serving these juventles and their fantlies (Powell, 1975, b.).

\section{AGENCY STAFPING}

The S.0.H.C. Project is a relatively pmall agency with a total of eight (8) staff. Included is the project director, three resource developers, one rallef parent, project secretary, a project recentioniat, and one Netighborhood Youth Corps student who works as a clerfical assistant at a matmun of 25 hours a week.

The staff t S.O.H.C. concentrate on Identifying particular needs of cllents and matching these needs with care providers ta assure quality service and care. The resource developers provide on-going consultation, support and Ilaison to care providers, assisting them in meeting the needs of the clients. Each of the three fosource developera carries a 


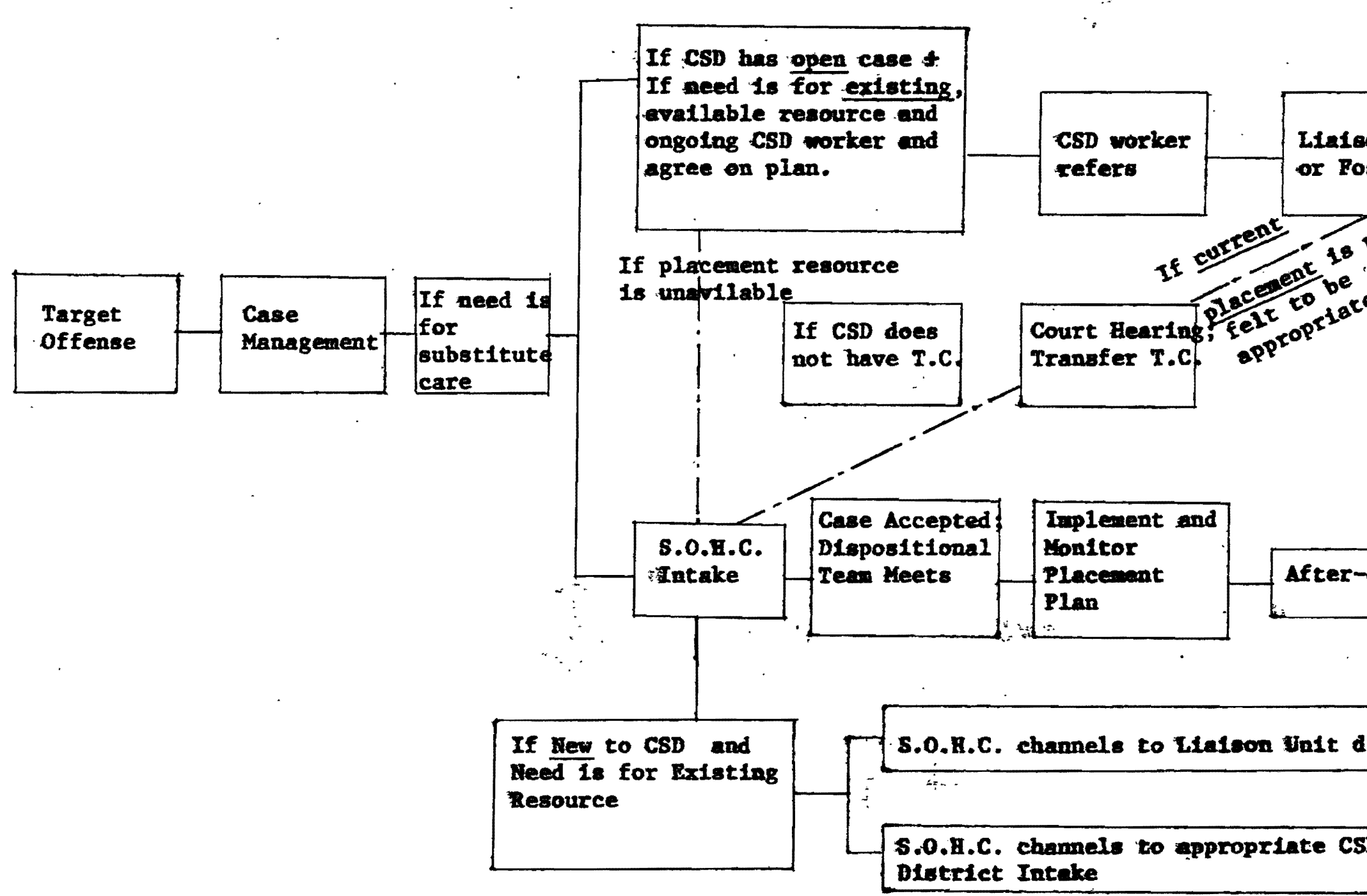

P1gure 3. Flow Chart of Case Management Referrals to C.S.D. for Out-of-Home Care, August 1974. 
case load of approxinately twenty (20) youths. In addition to their caseload, each resource developer is assigned an additianal responsibility. One is a Ilaison worker to the new Bethel Bffective Comuntty Adjustnent (B.B.C.A.P.) day-care center and to also the priany vorker for all the youth assigned to that program. The second resource developer also gesupes the role of an Intake coordinator. The third regource developer acts as a lialson worker with two of the group care contractors

- RIver Forest House at Youth Adventurers, an S.0.H.C. funded program; and JANIS, spectalizing in drug rehabilitation through five group homes. The main responstbilfties of the relief parent are: 1) to broaden experiences for the clients, as well as, 2) to give the providers an opportunity for a weekend or evening reat. The relief parent provides rellef gervices to a minimum of elght foster care providers each month. The current rellef parent is a ale who is experienced in youth work and reçeationpl activities. He if under contract through the W.M.C.A., but works directly out of the S.O.H.C. office.

\section{S.0.H.C. PLACEMENT RESOURCES}

The S.0.H.C. Profect is unique in that it places an emphesis on spectalfzed foster care in which Individuals who have experience rorking Whth actingmout delinquent youth are employed on a full-time or part-time basts to work difectly with youth in their own home. It is the s.0.H.C. Project's intention that by placing a delinquent youth firat in this professional type faster care aetting that some unique opportunities become ayallable to the fuventle correctional system. The s.0.H.C. Profect's professional foster care placements represent a diverge range of 
care settings (Jenkins, 1974, b.). Bach of the s.0.H.C. settings is unique in the specific services offered by the provider and the atmosphere of the provider's home. All avallable S.0.H.C. settings are considered when the profect is determining the appropriate placement which will neet the neede of a particular s.o.H.C. client. A fanily-type atmosphere; for example, would be nost appropriate for a youth who needs exposure to healthy parental rolos and fanily-style living patterpe. Single parent households, on the other hand, are best sulted for S.0.H.C. clients who need an Intense one-to-one relationship. Some of the speclallzed services avallable in these various settings consist of: wilderness outing experiences, behavior modification programs, expoeure to survival sk11ls, and development of emancipation sk111s.

Durting the end of the first fiscal year (June 1975), S.O.H.C. had under coptract fourteen (14) famlly foster care sattinge serving approxinately fifty (50) "Juventles, Twelve of these families were Caucasion, one Indian, and one Black. In addition, s.o.H.C. utilized geven single foster parent placement settings, of which four were Black. Approximately thifteen youths had been placed with single parent hougehold providers.

The S.O.H.C. Project has also purchased slots from threp existing repidentlal care programs - JANIS, Youth Progress, and Klamath Lake Youth Ranch. Thus, several types of group care prograps are available for the S,Q.H.C. client. In addition, two new prograns contracted through S.O.H.C. have been created. One is the B.E.C.A.P. "Day Center" in N.R. Portland wich concentrates on target offenders who continue to remain in their own homes, but have need of supervision, cultural, and recreational activities, and peer group experiences. The other is a 
group hone, a pllot profect through Youth Adventures, located outside Oregon C1ty. Th1s program serves six (6) youths.

Thls spectrum of placement settings was purposely arranged to neet the varled needs of the s.0.H.C. clients. The family-type environnent, where both mother and father are lavolved full-tine in the praject and work as a team In terms of providing services to the youngeters placed in their care, stresses the Involvenent of the youthe in fenfly-ortented experiences and activities. The professtonal Big Brother or Big Sister format, wherein the single Individual has placed with him/her one to three adolescents, primarily provides an intense one-to-one ralationghtp with the adult. This type of setting stresses comunlty recreation and tipe wanagement issues. For adolescents who require less intense supervision, the S.O.H.C. Project has some familles in which one parent (elther the wan or the woman) works outside of the home. An adolescent would be placed in this particular setting mainly to alter his/her enviropment with ințensive services, but less required supervision (Powell, 1975, a.).

Paymẹt for these professtonal providers vartes depending on the numbers of clfents placed in the home, the specific need of the clients placed, and the amount of time contracted by s.o.H.C. with the provider. The average costs per month for care of an S.O.H.C. client in different placement settings during the 1974-75 fiscal year were as follows: 1) $\$ 820.89$ per month for group home settinge (JANIS, Youth Adventures, Youth Progress, and Klanath Lake County Youth Ranch), 2) \$637.95 In two-parent family settings, and 3) $\$ 629.69$ in single-parent (B1g Brother/B1g Sister) placements. (For more complete cost analysis see TABLE I).

A unique feature of contracting for professional foster care ser 
TABLE I

$$
\begin{aligned}
& \text { FISCAL DATA -- S.0.H.C. } \\
& \text { (PIscal Year 1975) }
\end{aligned}
$$

\begin{tabular}{|c|c|c|c|}
\hline & $\begin{array}{l}\text { Average Monthly Pla } \\
\text { Ju1. 74-Dec. } 74\end{array}$ & $\begin{array}{l}\text { ament Costs Per slot } \\
\text { Jan. } 75-J u n .75\end{array}$ & Total \\
\hline $\begin{array}{l}\text { Group Care } \\
\text { Projected } \\
\text { Pccupled }\end{array}$ & $\begin{array}{l}\bar{X}=\$ 510.63 \quad(\mathrm{~N}=8) \\
\bar{x}=\$ 672.40 \quad(\mathrm{~N}=5)\end{array}$ & $\begin{array}{l}\bar{x}=\$ 816.58(4-19) \\
\bar{X}=\$ 873.93(4-14)\end{array}$ & $\begin{array}{l}\bar{X}=\$ 725.93 \quad(N=27) \\
\bar{X}=\$ 820.89 \quad(N=19)\end{array}$ \\
\hline $\begin{array}{l}2 \text { Parent F.C. } \\
\text { Projected } \\
\text { Occupled }\end{array}$ & $\begin{array}{l}\bar{X}=\$ 525.26 \quad(\mathrm{~N}=19) \\
\bar{X}=\$ 755.00 \quad(\mathrm{~N}=9)\end{array}$ & $\begin{array}{l}\bar{X}=\$ 554.42 \quad(\mathrm{~N}=38) \\
\bar{X}-\$ 603.97(\mathrm{~N}=31)\end{array}$ & $\begin{array}{l}\bar{x}=\$ 544.70 \quad(N=57) \\
\bar{x}=\$ 637.95 \quad(N=40)\end{array}$ \\
\hline $\begin{array}{l}1 \text { Parent F.C. } \\
\text { Projected } \\
\text { Occupted }\end{array}$ & $\begin{array}{l}\bar{X}=\$ 527.50 \quad(N=18) \\
\bar{X}=\$ 726.00 \quad(N=10)\end{array}$ & $\begin{array}{l}\bar{x}=\$ 524.83(N=29) \\
\bar{X}=\$ 587.83 \quad(N=23)\end{array}$ & $\begin{array}{l}\bar{X}=\$ 525.85 \quad(N=47) \\
\bar{X}=\$ 629.69 \quad(N=33)\end{array}$ \\
\hline $\begin{array}{l}\text { Day Care } \\
\text { Projected } \\
\text { Occupled }\end{array}$ & - & $\begin{array}{l}\overline{\mathrm{X}}=\$ 279.80(\mathrm{y}-20) \\
\overline{\mathrm{X}}=\$ 279.80(\mathrm{~K}=7)\end{array}$ & $\begin{array}{l}\bar{X}=\$ 279.80 \quad(N=20) \\
\bar{X}=\$ 279.80 \quad(N=7)\end{array}$ \\
\hline $\begin{array}{l}\text { Special } \\
\text { Situation } \\
\text { Projected } \\
\text { Occupled } \\
\star\end{array}$ & -- & $\begin{array}{l}\bar{x}=\$ 434.16 \quad(\mathrm{~N}-6) \\
\bar{x}=\$ 532.66 \quad(\mathrm{~N}-3)\end{array}$ & $\begin{array}{l}\bar{X}=\$ 434.16(\mathrm{~N}=6) \\
\bar{X}=\$ 532.66(\mathrm{~N}=3)\end{array}$ \\
\hline
\end{tabular}

* excludes one independent living situation 
vices is that the amount of compensation 18 negotiated individually with each provider versus a standardized foster care rate. Further, payment to the provider is two-part. The first is relmbursement for out-ofpocket expenses, 4.e., room and board, transportation, allowances, and recreation. The second is compensetion for services readered, in aense 4 "salary". As such, each provider to a ealf-employed contractor whose Income 1s subject to taxntion.

Cllents vere channeled out to other resourcea by the S.O.H.C. staff If It vas, 1) the expressed chotce of the cllent's Case Yanager, and 2) If there were already existing resource avallable. The s.0.H.C. Project recognized the limitations of their. own resources and the fact that sone already existing comanity resources could not be duplicated. It was felt that these resources would be wore appropriate in weetipg the needs of these particular clients. Hera, other exlsting resources encoppassepd anything from the client's own houe to alternative group care, 1.e., Youth Adventures.

IV. PROVIDER TRAINING

During the fiacal year 1975 a wide varlety of training programs were offered to providers. Spectal sessions on delinquent behavior typologies, "gamey" behavior, Transactional Analysis concepts, and a Family Therapy workshop using role playing, were some of the alternatives provided. Individual consultation with Ken Klesel, one of the providers, was also avallable to other providers. Also, several social get-togethers were held for Case Managers, S.O.H.C. staff, and providers. Since the 1975 flscal year other provider training sessions have been Initiated. 
It is the feeling of the S.O.H.C. Project staff that these varlous trainIng opportunities have had an Impact on profeselonalizing their foster parents and creating a sense of unlty among then (Povell, 1975, a.).

\section{v. SUMAARI}

In conclusion, the S.O.H.C. Project seeks to broaden the range of substitute care, butld and nurture a netyork of professional fopter parents capable of working intensively with hard-to-manage adolescente, and nodel an Intake and case planning system. The overall goals are to roduce the incldence of target offenses anong clients served and to provide the clients with the tools necessary to enable them to function wore aatIafactorily at home and in thefr compunity (Powe11, 1975, c.). 


\section{CHAPEER IV}

METHODOLOGY

The purpose of this resench practicum was to conduct an outcone atudy on the Inpect of the S.O.H.C. Project on Ite cllent: A camparim son aaple, clients who had been referred to s.o.H.C., but vare placed In regular out-of-home placenents or returned home, was mensured over the ane perfod of time againat the S.Q.H.C. group. The S.0.H.C. Project was chosen because of uplqueness in dealisg with already Identified fuvenile delinquents in the Rortland, Oregon Area. By the use of prafesslopalfzed out-of-home care, It was felt that the dolinquents placed within sp S.0.H.C. resource would be facilitated in making positive behavior change.

It vas orfginally hoped that three-way copparison study could be ade of the cllenta according to the following criterla: 1) cliente placed in $\mathbf{S . 0 . H , C . ~ r e s o u r c e s , ~ 2 ) ~ c l l e n t s ~ p l a c e d ~ i n ~ r e g u l a r ~ C h I l d r e n ' s ~ S e r - ~}$ vices Division resources, and 3) cilents who did not recelve any out-ofhome care. Because of the small sample alze of the last group, a twoway comparison was made between the combined A.0.A.C. and clfent group (who did not recelve any out-of-home care seryices), and the S.o.H.C. 8roup.

To begin the study, Information was taken from the ortginel Needs Assessment Form which was completed on 126 cllents referred to the S.0.H.C. Project during the fiscal year 1975 (July 1974-June 1975). The orfiginal 
Need Assessment Borm was designed by the S.0.H.C. Project taff and vartoug C.M.C.S. officee. Several changes were made in the Heed Assesspent For uptil it was final1xed In September 1974. This finalized draft was structured in order to facllitate computer coding. The purpose of the forp was to provide the S.0.H.C. resource developer with an overview of the prospective cllents to ald In the placenent process. A sumpary description of the client population is included in the follaring ebapter.

After wych discussion regarding possible evaluatlon dentgns anong the project evaluator, the practicum advisor, and the students, it was agreed to do in update questionnaire on the Needs Assesgment. This would then be distributed to the Case Manager, who carried the client in her/his caseload. It was felt that the Case Managerg, bacauge of their unique position with small caseloads and Intensive services, would have sufficient knowledge of the cllent to answer the questlons adequetely. By foing ap update Needs Assessment, the resenchere could approximate the pre-test/post-teat experimental design.

The orfginal yeeds Assessment was revised for the update questionnalre." Much of the Information on the original was deleted to enge completion by the Case Managers. The update form focused on the data the researchers felt would be wost impacted on by the project. Thio included primarify the proble areas and the motivation/capacity questions for both the client and her/his parants. By using both motivation/capacity questions and the problem areas, the update form wopuld reach simultaneousIy a psychological evaluation and a behavioral thesenre. Tame hasic phrasing was used in both the original and the update forms to maintain continuity. The researchers realized some of the problen areas were not 
defined as clearly possible, but felt the continuity aspect was more Important. The updated Heed Assesement also asked movenant dats on number of placements, types of placements, and length of atay for each clfent. In an attempt to measure whether a problem area had inproved or deterforated, a rate of change scale was Included with each problem axea. This would provide wore information than the straight yes/no response on the orlginal Needs Assescment Forw. (Spe Appendix B for coples of both forms ?)

Once the Needs Assessment Update wos revised, a memo was sent to the supervisorg of the Case Hanagars Carrections Services to Inform them of the upconing evalustion. Practicun etudents went out to each supervisor to distribute and explain the updated forms. The superwisor then distributed then to the Case Managers. The students followed through on answering questions about the form and obtaining the completed forms. Circulation to the Case Managers occurred In November, 1975 wth completed forgs in by Decenber 1, 1975. The Case Managers filled out the forms according to current cllent/parent behavior as of 0ctober 31, 1975. Data vas then coded and placed on computer cards for data analysis.

After an over-all frequency count on the total client population (1-126), the clients were divided into two groups: thope who had spent a month or more in s. S.O.H.C. placement and those who did nat. The S.O.H.C. group consloted of 82 clients; the non-S.0.H.C. group, 44 clients. The non-S.0.H.C. group Included clients who had less than one wonth in S.0.H.C. $(\mathrm{N}-16)$, those who were in R.O.H.C. $(\mathrm{N}-11)$, and those wo did not have out-of-home care $(\mathrm{N}=17)$.

To analyze the gathered data, two basic manipulations vere per- 
formed. The first operation was a frequency count of motivation/capacity scores and behavioral problem areas for each group. This data was tabulated and the means calculated for the motivation/capacity scores.

The second analysia consisted of cross-tabulating the scores for each Individual between pre-and post-test motivation/capacity items and problem areas. Four-fold tables vere constructed showlng, A.) the number of cllents who had the problem on the pre-test but did not hove the problem on the post-test or who went from low to high motivation/capacity scores, B.) those who had the problem both times or who had loy motivation/ capacity scores both times, c.) those who did not have the problem eithef time or who had high motivation/capacity scores both times, and p.) those who did not have the problem the first time but did the second or who went from high to low motivation/capacity scores. (Figure 4).

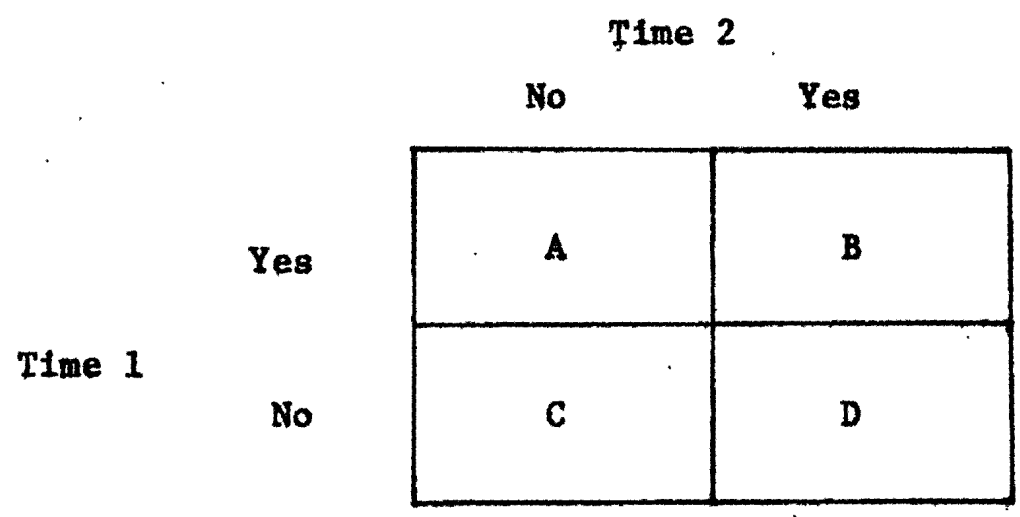

Flgure 4. Four-fold Table.

If the program had no effect, one could expect by chance that half of the clients would stay the same and half would change. Of those who changed, half would get better; the others, worse. The McNemar test measures the significance of the direction and amount of change using the formule $x^{2}=\frac{([A+D]-1)^{2}}{A+D}$ with the correction for continuity at one degree 
of freedom (Siegel, 1956). If the $x^{2}$ value is greater than 3.8 , the probability that the change 18 signiflcant and not due to chance is .95. The McNemar test was run on the problem areas for the 8.0.H.C. group where 20 percent or more of the cllents anowered yes to having problem on the preptest. This was done to insure a large enough papple for the test to be yelid. For those in the non-S.0.H.C. group, the tept vas used when the expected frequepcy, $\frac{A+D}{2}$, was greater than 5 . A gmaller frequency vould invalidate the test (Siegel, 1956). There vare nine problew areas that could be tested for both the S.O.H.C. and the non-S.O.B.C. groups. In addition, ix problem areas were tested for fuat the s.o.H.C. population.

The wedtan points on the pre-test capacify/motivation itens were uned as a difding line between high and low motivation/capactey scores. A four-fold table was then conatructed and the fackenara teat of aigniflcance vas performed. 


\section{CHAPTER V.}

\section{DESCRIPTION OF CLIBNT POPULATION}

The purpose of this project is to provide an outcome study of the Speclalised Qut-of-Home Care Project adminietered by the Children's Services Division in cooparption with the Case Kanagenent Tean of Multnomah County. Demographical data vas collected frow the inforation contained In the original Heed Assessment Form (Form 1.0) on each \$.0.H.C, referral during the 1975 fibcal year (July 1974-June 1975). A total of 181 referrals yere made from the Case Manggenent Tean to the S.o.H.C. Project during this period. The descriptive data contained in this sectIon was taken from 126 completed Needa Assessment Porms.

Th1 sectiop oumar1ze the dewographtcal characteristics of these 126 feferrals. The data to prepented under the arens of: 1) Deacriptive Information on the Client Population, 2) Descriptive Information on the Client' Fanily, 3) Descriptive Information on the Client's Identifled Problen Areas, and 4) Descriptive Information on the Client's Placement Meeds.

Denographical Information was taken from a computerized print-out, which vas made avallable by the S.0.H.C. staff.

DESCRIPTIVE INFORMATION ON THE CLIENT POPULATION

TABLE II shows the dietribution of referrals by Case Hanagement offices vithin the Portland area. It should be noted that all referrals 
from the Southwest office were processed through the Southeast office.

TABLB II

SOURCE OF REFERRALS BX CMCS OFEICES

\begin{tabular}{lrrr}
\hline CACS Office & L & Z & Cun. I \\
\hline North Office & 26 & 20.6 & 20.6 \\
B. E. Union (Alb1na) & 29 & 23.0 & 43.6 \\
M.E. Multi-Services Ctx. & 21 & 16.7 & 60.3 \\
Southeast Office & $\frac{50}{126}$ & $\frac{39.7}{100.0}$ & 100.0
\end{tabular}

Referrals were wade by all four of the aycs offices in various Portland locations. A larger number of S.O.H.C. clients are ghown to be coming put of the southenst office $(39.7 \%)$. This large statiatic is probably due to the inclusion of the referrals from the soutbwet area. Other S.0.H.C. clifents were pretty evenly distributed anong the North office, N.E. Union office, and the N.E. Multi-Service Center.

TABLE III shows the age distribution of \$.0.H.C. referrals accordIng to frequency, percentage and cumulative percentage.

TABLE III

AGR DISTRIBUTION

\begin{tabular}{crrr}
\hline Age & N & \multicolumn{1}{c}{ \% } & Cue. $z$ \\
\hline 11 & 3 & 2.4 & 2.4 \\
12 & 10 & 7.9 & 10.3 \\
13 & 21 & 16.7 & 27.0 \\
14 & 33 & 26.2 & 53.2 \\
15 & 33 & 26.2 & 79.4 \\
16 & 15 & 11.9 & 91.3 \\
17 & 8 & 6.3 & 97.6 \\
Unknown & 3 & 2.4 & 100.0 \\
& 126 & 100.0 & \\
\hline
\end{tabular}


The age distribution of the S.O.H.C. clients tends to be cantered In the early teens. The mode score of the population is in the fourteen and fifteen age group. The range of the ages are eleven to peventepn years, ytth mean age of 14.3 yeara.

The sex distribution of S.0.H.C, referrals is shown in IABLE IV. Soctological studias Indicate that nore males than fenales are involved in delinquency (See revien of the ilterature).

TABLE IV

SEX DISTRIBUTION

\begin{tabular}{lrr}
\hline Sex & N & $\%$ \\
\hline Male & 112 & 88.9 \\
Female & $\frac{14}{126}$ & $\frac{11.1}{100.0}$
\end{tabular}

TABLE IV hows clearly that the cllent population in the s.Q.H.C. Project also reflects this trend, The statiatics indicate that almost 90 percent of the S.O.H.C. referrals are comprised of males.

TABLE $\nabla$ Indfcates the major ethnic groupings of the S.O.H.C. cllentele.

TABLE V

\section{ETHNICITY}

\begin{tabular}{lrrr}
\hline Ethnic Group & N & \& & Cum. Z \\
\hline White & 83 & 65.8 & 65.8 \\
Black & 33 & 26.2 & 92.0 \\
Mexican American & 1 & 0.8 & 92.8 \\
American Indian & 6 & 4.8 & 97.6 \\
Unknown & $\frac{3}{126}$ & $\frac{2.4}{100.0}$ & 100.0 \\
\hline
\end{tabular}


Ethnic characteristics of the S.0.H.C, population prodoninate in the White ethnic group $(65.8 \%)$ with a little over one-fourth coning from the Black group (26.2\%), Fewer than $5.6 \%$ of the population are of Maxican Amertcan or American Indian descent. These S.Q.H.C. ethnic percentages do not reflect the nost racent population cenous count in the cfty of Portland. According to the 1970 ceneus, the city of Portland has a 94.03\% White population. The Black population is $5.75 \%$ and the American Indian represents . $52 \%$ of the Portland ethnic population. Other minorit1es make up . $34 \%$.

The distribution of S.O.H.C. ellents with physical or mental disabilities at the time of referral are indicated in FABLE VI:

\section{TABLE VI}

PHYSICAC OR MENTAL DISABILITY

\begin{tabular}{lrrr}
\hline DIsablifty & N & $Z$ & Cum. Z \\
\hline Epilepsy & & & \\
Speech Inpairment & 1 & 0.8 & 0.8 \\
MIld Mental Retardation & 1 & 0.8 & 1.6 \\
Other Disability & 13 & 1.6 & 3.2 \\
Not Applicable & 10.3 & 13.5 \\
& $\frac{109}{126}$ & $\frac{86.5}{100.0}$ & 100.0
\end{tabular}

A majority of the clients exhibit no presenting disability $(86,5 \%)$. The category, "other disabilitiea", seems to indicate that other organic and perhaps mental disabilities are more compon.

TABLE VII shows the number of previous out-of-home placenents of S.0.H.C. clients. 
TABLE VII

PREVIOUS OUT-OF-BOME PLACEMEMTS

\begin{tabular}{crrr}
\hline Number of Placements & $N$ & $q$ & Cun. $Z$ \\
\hline & 73 & 57.9 & 57.9 \\
None & 25 & 19.8 & 77.8 \\
1 & 11 & 8.7 & 86.5 \\
2 & 9 & 7.1 & 93.7 \\
3 & 1 & 0.8 & 94.4 \\
4 & 1 & 0.8 & 95.2 \\
5 & 1 & 0.8 & 96.0 \\
6 & 2 & 1.6 & 97.6 \\
7 & 1 & 0.8 & 98.4 \\
16 & 2 & 1.6 & 100.0 \\
Unknown & 126 & 100.0 & \\
\hline
\end{tabular}

Seventy-three clients had no previous out-of-home placements prior to entering S.O.H.C. The table show that $35.6 \%$ of the referrals have had one to three prior out-of-home placenents. of the remaining clients, 6.4\%.had a range of four to sixteen prepious placements.

Academic achievement of the S.0.B.C. referrals is shown in TABLB VIII by 11sting number and percent of cllents at varlous grade, math, and reading levels. For a mafority of S.0.H.C. cllents, Case Managers were unable to assess the math and reading leyels. Of those known to the Case Managers, the math and reading levels are scored somewhat lower than the grade level of the client. Twenty-one perceptc fall within the seventh to ninth grade wath level, whereas $23.8 \%$ fall within the seventh to ainth grade reading leve1. A majority of S.0.H.C. referrals $(81.8 \%)$, as indicated by the first two coluwns, fall between the seventh and tenth grade level academically. 
TABLE VIII

ACADEMIC ACHIEVEMTAT

\begin{tabular}{|c|c|c|c|c|c|c|}
\hline \multicolumn{3}{|c|}{ Grade Level } & \multicolumn{2}{|c|}{ Math Level } & \multicolumn{2}{|c|}{ Reading Level } \\
\hline Grade & II & 7 & $\mathrm{~N}$ & 7 & $\mathbb{4}$ & $\bar{x}$ \\
\hline $\begin{array}{l}\text { Th1rd } \\
\text { Fourth } \\
\text { Fifth } \\
\text { Sixth } \\
\text { Seventh } \\
\text { Bighth } \\
\text { Minth } \\
\text { Tenth } \\
\text { gleyenth } \\
\text { Twelveth } \\
\text { Upknown }\end{array}$ & $\begin{array}{r}0 \\
0 \\
5 \\
5 \\
16 \\
28 \\
37 \\
22 \\
4 \\
1 \\
\frac{12}{126}\end{array}$ & $\begin{array}{r}0.0 \\
0.0 \\
0.8 \\
4.0 \\
12.7 \\
22.2 \\
29.4 \\
17.5 \\
3.2 \\
0.8 \\
9.5 \\
100.0\end{array}$ & $\begin{array}{r}1 \\
3 \\
5 \\
7 \\
13 \\
6 \\
8 \\
2 \\
3 \\
0 \\
78 \\
126\end{array}$ & $\begin{array}{r}0.8 \\
2.4 \\
4.9 \\
5.6 \\
10.3 \\
4.8 \\
6.3 \\
1.6 \\
2.4 \\
0.0 \\
61.9 \\
100.0\end{array}$ & $\begin{array}{r}3 \\
4 \\
7 \\
5 \\
15 \\
7 \\
8 \\
3 \\
2 \\
0 \\
72 \\
126\end{array}$ & $\begin{array}{r}2.4 \\
3.2 \\
5.6 \\
4.0 \\
11.9 \\
5.6 \\
6.3 \\
2.4 \\
1.6 \\
0.0 \\
57.1 \\
100.0\end{array}$ \\
\hline
\end{tabular}

The type of school program in whtch the S.O.B.C. referrels were enrolled at the time of referral is shown in TABLE IX.

TABLE IX

TYPE OF CURRENT SCHOOL. PROGRAY

\begin{tabular}{|c|c|c|c|}
\hline Type of Program & $\mathrm{N}$ & $\bar{z}$ & Cum. 8 \\
\hline $\begin{array}{l}\text { Regular Public School } \\
\text { Alternstive Education } \\
\text { Truant mare than } 1 / 3 \text { of } \\
\text { last year } \\
\text { Mot empliled } \\
\text { Uakngmp }\end{array}$ & $\begin{array}{r}64 \\
18 \\
18 \\
33 \\
\quad 3 \\
126\end{array}$ & $\begin{array}{r}50.8 \\
14.3 \\
6.3 \\
26.2 \\
2.4 \\
100.0\end{array}$ & $\begin{array}{r}50.8 \\
65.1 \\
71.4 \\
97.6 \\
100.0\end{array}$ \\
\hline
\end{tabular}

S.0.H.C. clients vere most likely attendlag a regular public school (50.8\%) prlor to thelr referral to the Project. When alternstive educat1on is considered, $65.1 \%$ of the referred population was Involved in a school program. Cllents not recelving education totaled a little more than one-fourth of the population. 
II. DESCRIPTIVE INFORMATION ON THE CLIENT'\$ FAMILY

TABLE X shows the parental composition of the refgred s.0.H.C. clients.

TABLE $X$

PAREATITAL COMPOSITION OF CLIENT'S FAMUI

\begin{tabular}{lrrr}
\hline \multicolumn{1}{c}{ Conposition } & N & \multicolumn{1}{c}{ C } & \multicolumn{1}{c}{ Cum. Z } \\
\hline Two Parent (8table marrlage) & 34 & 27.0 & 27.0 \\
Two Parent (unstable marriage) & 16 & 12.7 & 39.7 \\
One Parent (Mother flgure) & 50 & 39.7 & 79.4 \\
One Parent (Pather figure) & 10 & 7.9 & 87.3 \\
Other & 15 & 11.9 & 99.2 \\
Unknown & $\frac{1}{126}$ & $\frac{0.8}{100.0}$ & 100.0 \\
\hline
\end{tabular}

Over one-half of the S.0.H.C. clients come frop one-parent families $(A=60)$. Of these, $39.7 \%$ come from a home where the one-parent figure is 4 Mother. Two-parent fantlles (39.7\%) were mostly deecribed by Case Management as stable. Over-all, TABLE $\mathrm{X}$ shows that a Mother figure was found to be a part of the cllent's household a majority $(66,7 \%)$ of the time.

The kinds of parental change needed by the client's mothey/father are Indicated in TABLE XI. TABLE XI hovg that a majority of Case Managers selected the "Other" category when looking at change nost needed by both parents of the S.O.H.C. client. This category represents a wide varlety of responses spectfled by the Case Manager on the or 1 gthal Needs Assessment Forw. In looking at the descriptive categorles, pothers and fathers scored relatively the same in two areas: on "resolving own emotional or personal problems," $13.5 \%$ of the mothers were seen as needing 
improvenent coppared to $10.3 \%$ of the fathars. Case Hanagers av $12.7 \%$ of the mothers and $13.5 \%$ of the fathers as needing work on "Improving comanication and interpersonal relationships with their child." Kothere were seen as needing more work on "learn or Improve disciplinatry techntques". (19.0\%) than fathers (8.7\%).

\section{TABLE XI}

CHAMGE MOST NEEDEP BY MOTHER/RATHER

\begin{tabular}{|c|c|c|c|c|}
\hline Parental Change & \multicolumn{2}{|c|}{ Mother } & \multicolumn{2}{|c|}{ Father } \\
\hline & $\bar{I}$ & $\bar{z}$ & $\bar{n}$ & $\bar{z}$ \\
\hline $\begin{array}{l}\text { Resolve own emotional or } \\
\text { Interpersonal problems }\end{array}$ & 17 & 13.5 & 13 & 10.3 \\
\hline $\begin{array}{l}\text { Learn of improve disciplinary } \\
\text { techniques, etc. }\end{array}$ & 24 & 19,0 & 11 & 8.7 \\
\hline $\begin{array}{l}\text { Learn to be consistent in } \\
\text { disciplining }\end{array}$ & 2 & 1.6 & 1 & 0.8 \\
\hline $\begin{array}{l}\text { Imprave compunfcation and } \\
\text { interpersonal relation- } \\
\text { ships with child }\end{array}$ & 16 & 12.7 & 17 & 73.5 \\
\hline $\begin{array}{l}\text { Learp to reward positive } \\
\text { behaviors of the child }\end{array}$ & 0 & 0.0 & 1 & 0,8 \\
\hline $\begin{array}{l}\text { Other } \\
\text { Unknown }\end{array}$ & $\begin{array}{r}53 \\
14 \\
126\end{array}$ & $\begin{array}{r}42.1 \\
11.1 \\
100.0\end{array}$ & $\begin{array}{r}29 \\
54 \\
126\end{array}$ & $\begin{array}{r}23.0 \\
42.9 \\
100.0\end{array}$ \\
\hline
\end{tabular}

The rated frequency of motivation/capacity for change of each parent (on a scale of one to nine) is shown in TABLE XII.

TABLE XII

MOTIVATION/CAPACITY TO CHANGE BY MOTHER/FATHBR

\begin{tabular}{lrrrrrrrrrrrr}
\hline & (10w)1 & 2 & 3 & 4 & 5 & 6 & 7 & 8 & 9 (high) uniknown $~$ \\
\hline & & & & & & & & & & \\
\hline
\end{tabular}


TABLE XII clearly indicates that the parents of the S.O.H.C. cllepts were seen by Case Manager as having low motivation and capacity to change the behavior indicated In TABLE XI. The nean scores for the Mother's motivation and capacity to change were found to be 3.84 and 3.77 respectively. Mothers, however, were rated as having a higher level of motivation and capacity than Fathers who were givap wean score of 3.70 for motivation and mean score of 3.57 for capmeity. Bxcluding the "unknown" category, mode score for Mother's potivation and capacity were 3,7 , and 3 , respectively. Father's mode core for both axeas was 1.

\section{DESCRIPTIVE INFORMATION ON THE CLIENT'S PROBLEM AREAS}

TABLE XIII, "Problem Areas of Clients" gives an overvlew of problems Identified by Case Managers as characteristic of the S.O.H.C. population. Identified problems have been categorized in six descriptive behaviora.

"Blzarre Behavior Problems" comprises the lowest number (21.5\%). of the S.O.H.C. population. The most frequently occurring, "Property Destruction" behaviors, occurred within the school (33.3\%). Other behaviors within the "Property Destruction" category involved a little pver onefourth (25.4\%) of the identified problem behaviors of the population.

Under category "C", "Assault Problems," 37.32 of the S.0.B.C. population were identifled as physically assaultive with peexs at school. Assaultive behaviors toward younger siblings, nelghbors, adults, peera, and younger children in the neighborhood totaled over one-half $(66.7 \%)$ of Identified behavior problems. 
TABLE XIII

PROBLEA ARBAS OP CLIENTS

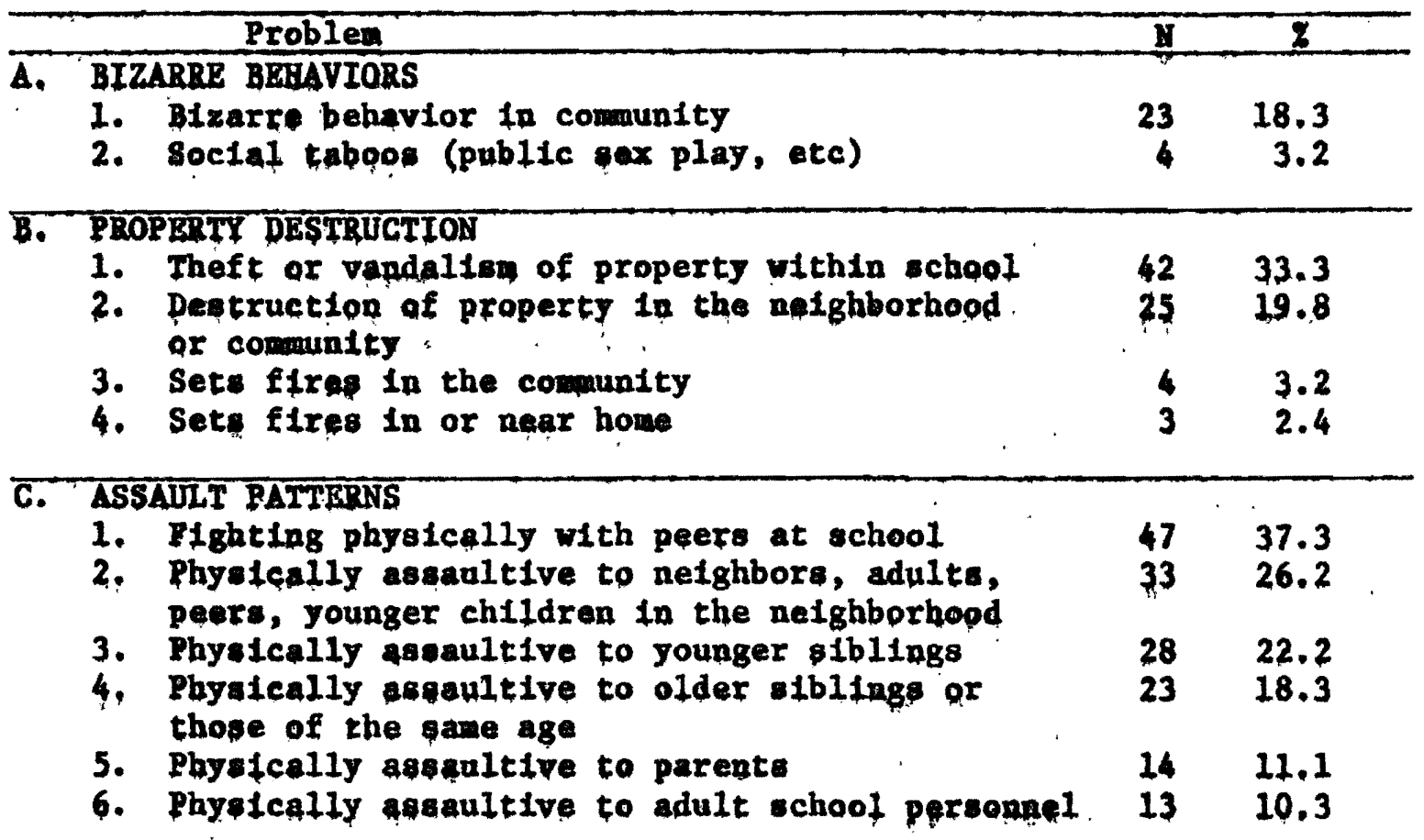

D. DRQG/AICOLOL ADDICTIOA/BABITUATION

1. Uses marfjuapa $\quad .74 \quad 58.7$

2. Uaen other drugs $\quad 33 \quad 26.2$

3. Bxcenalye use of alcohol

4. Pushing druge at school or in the compunity 9.1

5. घeep heroln

E. IMCORRIGIBILTTY AND STATUS ORFEMSES

1. Virtualfy no complifance to parental requegto $81 \quad 64.3$ or '11mits

2. Excessive truancy

$82 \quad 65.1$

3. Non-production at school

$83 \cdot 65.9$

4. Refusal to eccept/perform routine $\quad 76 \quad 60.3$

responsibilities at home

5. Verbally antagonistic ap as to continually $\quad 60 \quad 47.6$ diprupt the family

6. Runavay from home

$54 \quad 42.9$

7. Continually diaruptive to the class at school 1 i 32.5

F. THEFT AKD EXTORTION

1. Theft in neighborhood homes and stores $95 \quad 75.4$

2. Stealing from family nembers $51 \quad 40.5$

3. Extortion at achool from peers $\quad 10 \quad 7.9$ 
Karifuana use was rated the highest (58.77) Identffled behavior problem within the "Drug/Alcohol Addiction/Habituation" area. Excessive alcohol usage rated lower (15.1\%) than "other drug uaage" (26.2\%).

"Incorr1gtb1lity and other Status offenses" Involved the wajority of \$.0.H.C. clients. No compliance to parental requeste or Ifafts, truanç, non-production at school, and refusal to accept household responstbilities were fncluded in over one-half $(60.3 \%)$ of the S.Q.H.C. behaviors.

In the area "Theft and Extort1on", theft In neighborhood hanes and storea $(75.4 \%)$ and stealing from fantly members $(40.5 \%)$ vare rated a the most frequențly occurring behaviọs,

TABLE XIV ghowe the motivation and capacity for change as rated by the Case Manager when the client first entared the project.

\section{TABLE XIV}

MOTIVATION/CAPACITY TO CHANGE BT CHILD

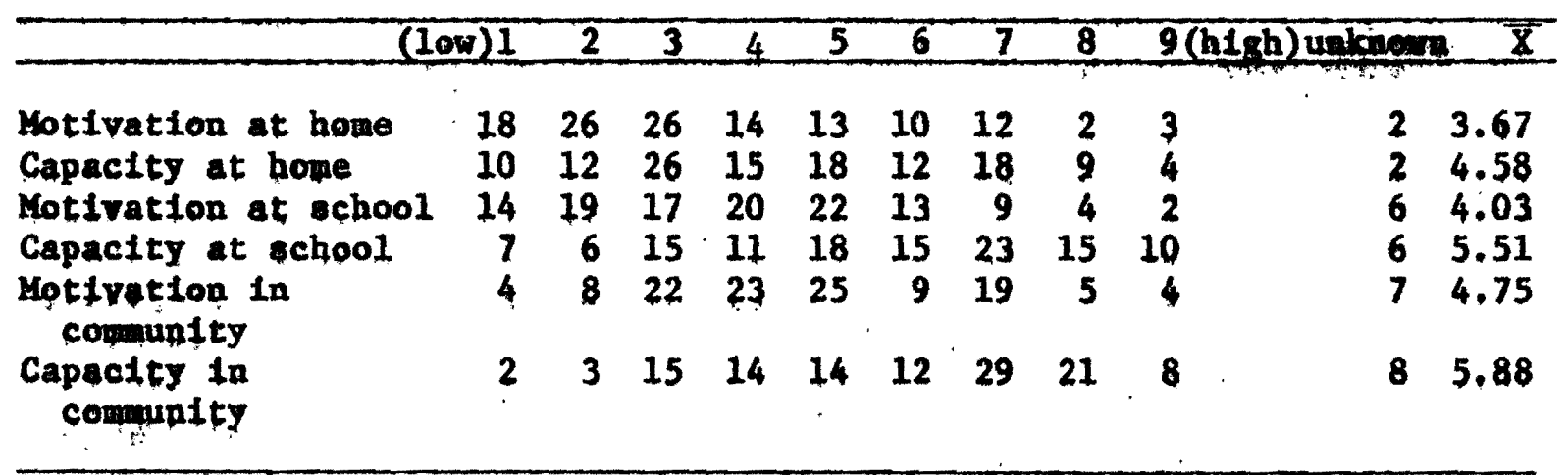

These figures Indicate that the S.0.H.C. client has nore motivar tion and a greater capacity than her/his parents (please refer to TABLE XII). The S.O.H.C. clients! capacity in the area of the hope $(\overline{\mathrm{X}}=4.58)$, school $(\bar{X}=5.51)$, and community $(\bar{X}-5.88)$ are rated higher than the 
clientg! motivetion in the same area. Over-all, the highest area of change for the S.O.H,C. client is seen in the compunty and thp lowest acore for change is ghown to be centered In the cllent's home.

IV. DESCRIPTIVE INFORAATION ON THE CLIEAT'S PLACEMEAT ABBDS

The educational program needed by the S.O.H.C. cllent is Indicated In TABLE XY.

TABLE XV

EDUCATIONAL PROGRAM MEEDED

\begin{tabular}{|c|c|c|c|c|c|}
\hline Progran Type & II & $\bar{z}$ & Educational Areas & I & $\bar{Z}$ \\
\hline $\begin{array}{l}\text { Programs within OHC facility } \\
\text { Speclally designed school } \\
\text { Alternative Education Program } \\
\text { Local public schools } \\
\text { Other } \\
\text { Un'snown/ Not Applicable }\end{array}$ & $\begin{array}{r}12 \\
12 \\
23 \\
45 \\
10 \\
24 \\
126\end{array}$ & $\begin{array}{r}9.5 \\
9.5 \\
18.3 \\
35.7 \\
7.9 \\
19.0 \\
100.0\end{array}$ & $\begin{array}{l}\text { Basis Academic skille } \\
\text { Vocational Skille } \\
\text { Survival Skill } \\
\text { Comblnation of above } \\
\text { Other } \\
\text { Unknown/ Not } \\
\text { Applicable. }\end{array}$ & $\begin{array}{r}35 \\
9 \\
3 \\
54 \\
3 \\
22 \\
126\end{array}$ & $\begin{array}{r}27.8 \\
7.1 \\
2.4 \\
42.8 \\
2.4 \\
17.5 \\
100.0\end{array}$ \\
\hline
\end{tabular}

Educatipnal needs of the S.O.H.C. cllents to be focuped on traditlonal academie ski11s. "Local public schools" (35.7\%) are seen as the most typical educational program needed by the S.0.H.C, population. An "Alternative Educational Program" is seen as the next apt typical program needed. Bducational areas designated most frequently by the Case Managers were basic educatlonal skills $(27.87)$ with nore enphasis on a combination of all three areas; basic academic, vocational, and survival ski11s $(42.8 \%)$.

TABLE XVI shows the varied placement needs of the S.0.H.C. referrals. These needs were Identifled by Case Managers on the original Needs Assessment Form at the time of client referral. 
TABLE XVI

PLACEMEAT NERDS OF CLIENTS

\begin{tabular}{|c|c|c|c|c|}
\hline Plac & enent Needs & & 4 & 8 \\
\hline A. & $\begin{array}{l}\text { TYPE OR SERVICE DESIRED } \\
\text { 1. Placement In existing C.S.D. reeource } \\
\text { 2. Placement if } \$ .0 . \mathrm{H} . \mathrm{C} \text {. resource } \\
\text { 3. Upcertain } \\
\text { 4. Other } \\
\text { 5. Unknowa/Hot Applicable }\end{array}$ & 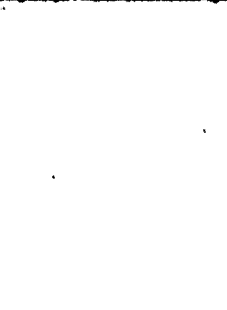 & $\begin{array}{r}35 \\
67 \\
13 \\
3 \\
8 \\
126\end{array}$ & $\begin{array}{r}27.8 \\
53.2 \\
10.3 \\
2.4 \\
\quad 6.3 \\
100.0\end{array}$ \\
\hline$\overline{\text { B. }}$ & 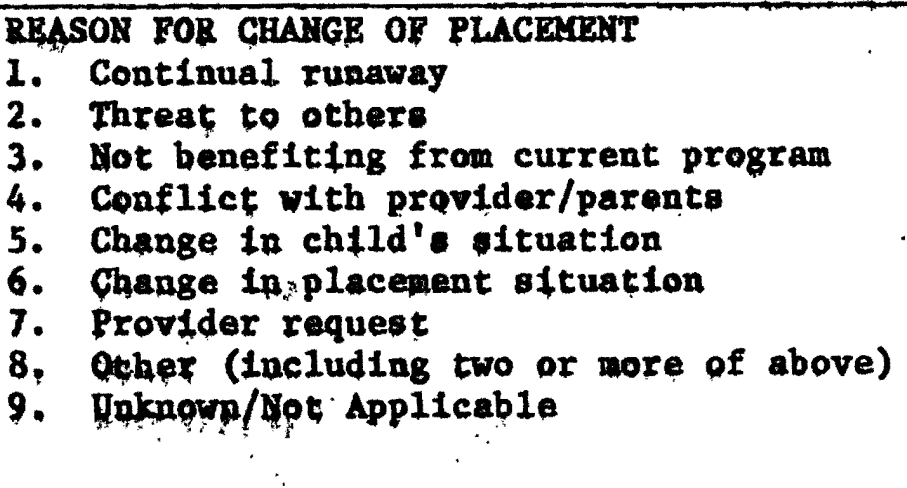 & & $\begin{array}{r}6 \\
3 \\
21 \\
25 \\
11 \\
3 \\
2 \\
33 \\
22 \\
126\end{array}$ & $\begin{array}{r}4.8 \\
2.4 \\
16.7 \\
19.8 \\
8.7 \\
2.4 \\
1.6 \\
26.2 \\
17.5 \\
100.0\end{array}$ \\
\hline$\overline{c .}$ & 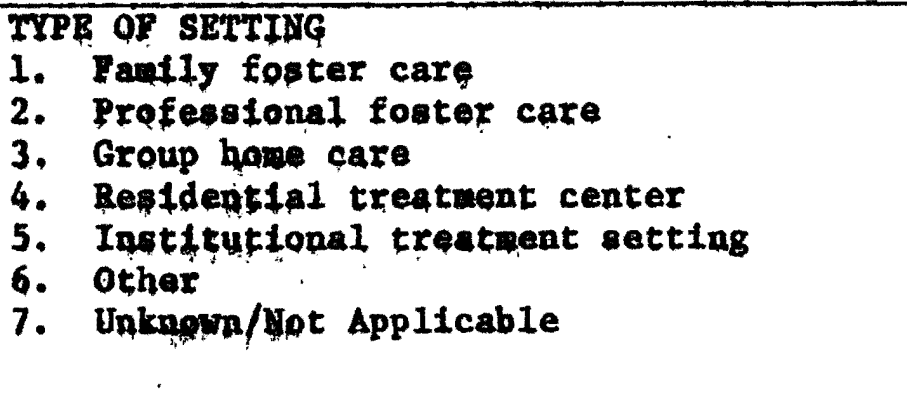 & & $\begin{array}{r}23 \\
31 \\
21 \\
10 \\
3 \\
3 \\
35 \\
126\end{array}$ & $\begin{array}{r}18.3 \\
24.6 \\
16.7 \\
7.9 \\
2.4 \\
2.4 \\
27.8 \\
100.0\end{array}$ \\
\hline$\overline{\mathrm{D}}$ & 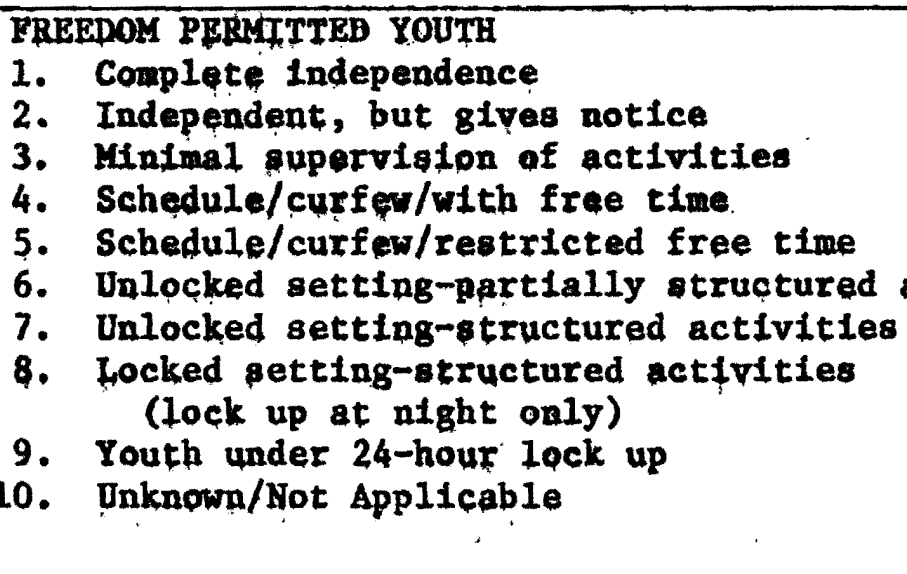 & activities & $\begin{array}{r}1 \\
1 \\
2 \\
18 \\
34 \\
25 \\
6 \\
1 \\
0 \\
38 \\
126\end{array}$ & $\begin{array}{r}0.8 \\
0.8 \\
1.6 \\
14.3 \\
27.0 \\
19.8 \\
4.8 \\
0.8 \\
0.0 \\
30.2 \\
100.0\end{array}$ \\
\hline
\end{tabular}


TABLE XVI (ContInued)

\begin{tabular}{|c|c|c|}
\hline P1acement Needs & $\overline{1}$ & $\bar{g}$ \\
\hline 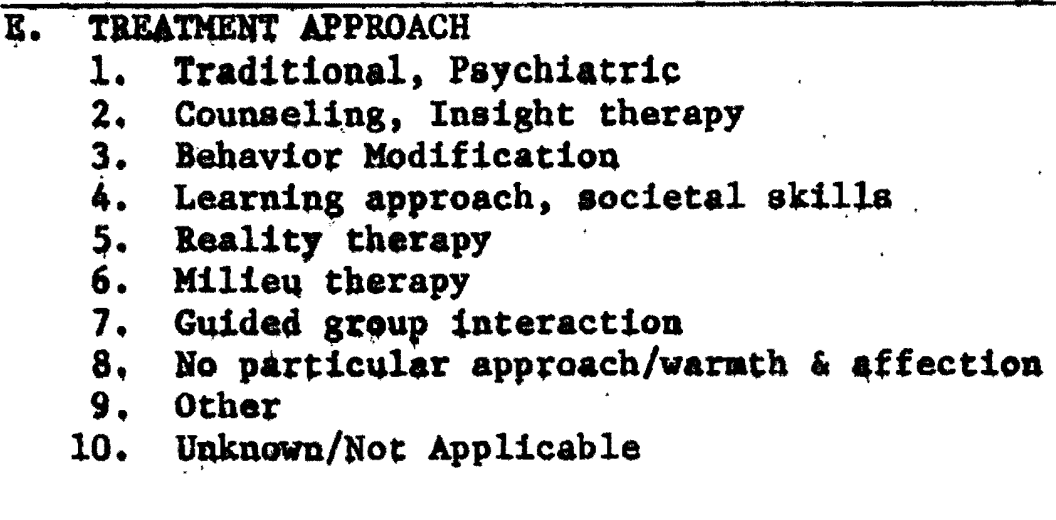 & $\begin{array}{r}3 \\
5 \\
28 \\
25 \\
9 \\
2 \\
1 \\
4 \\
21 \\
28 \\
126\end{array}$ & $\begin{array}{r}2.4 \\
4.0 \\
22.2 \\
19.8 \\
7.1 \\
1.6 \\
0.8 \\
3.2 \\
16.7 \\
22.2 \\
100.0\end{array}$ \\
\hline $\begin{array}{l}\text { PI. PLAMENT LOCATION } \\
\text { 1. Within 1mmediate nelghborhood } \\
\text { 2, Within same community } \\
\text { 3. Across town or Portland area } \\
\text { 4. Rural area near city } \\
\text { 5. Another area of the state } \\
\text { 6. Other } \\
\text { 7. Unknown/Not Applicable }\end{array}$ & $\begin{array}{r}2 \\
18 \\
40 \\
6 \\
6 \\
17 \\
37 \\
126\end{array}$ & $\begin{array}{r}1.6 \\
14.3 \\
31.7 \\
4.8 \\
4.8 \\
13.5 \\
29.4 \\
100.0\end{array}$ \\
\hline
\end{tabular}

FABLE XVI gives an overview of the placement need of the s.O.H.C. referrals, Over one-half of the referred clients (53.27) vere seen as needing placement in a s.o.H.C. resource. Client placesent in a regular exisţing C.S,p. resource vas Identifled a a benefictal placement for 27.82 of the referrals. Mast of the S.O.H.C. referrals came from a previous placement in which ohe/he was not benefiting from current program (16.7\%) and from placements where there was serfou conflict between the ch1ld and provider/parent (19.8\%). TABLE XVI does Indicate that referrals to the profect are more likely from a combination of reasons (26.2\%) than because of one particular situation.

Professional foster care 18 seen as the wost frequently needed set- 
ting for the S.0.H.C. cllent (24.6\%). Group home care (16.4\%) and fanily fogter care (18.3\%) are also seen as popular programs that are needed by other S.0.H.C. cllents.

Structure seems to be a key factor in the plecement setting. The alternative of "schedule/curfew/with restricted free time" was ppat freguent $7 y$ selected $(27.0 \%)$. An unlocked setting with wuch wore scheduling was peen as the next most frequent cholce of setting (19.8\%). A structured treatment approach, "Behavior Modiffcetion"; is rated as the most frequently requeqted approach (22.2\%) for S.0.H.C. clients. Learning approach vith societal skills is alse seen as valuable treatment modality $(19.8 \%)$.

Lost Cas Mangement personnel sav thelr cllents benefiting from a placement setting located across town or in the surrounding Portland area (31.7\%), A IIttle over 147 aw their s.0.H.C. clients residing Withif theif aame community with only 1.62 of the clients ataying within theif 1mandiate nelghborhoods. 


\section{CHAPTER VI}

\section{FINDINGS}

This chapter examines the update data collected on the 126 clfents which were in the Speclalized Out-of-Home Care Project during the 1974 fiscal year (July 1974 through June 1975). A statistical analyeis was used to measure the Impact of services provided by the S.o.H.C. Project. This update data was taken from a questlonnalre constructed frop a revised version of the original S.0.H.C. Needs Assessment Form (Form 1.0). The purpose of the update questionnaire was to obtain data that vauld Identify positive or negative changes occurring in the behaviors and attitudes of the S.0.H.C. clients over time. The update questionnalre was adminiştered to the C.M.C.S. Case Manggers during December, 1975.

The descriptive data on the 126 clients is presented in table form through the use of frequency tabulations and percentages. The descriptive data is presented in three areas: 1). Placement Data, 2). Client's Family, and 3). Problem Areas and Motivation/Capacity for Change.

Pollowing the descriptive information, the S.0.H.C. and the NonS.O.H.C. groups are compared, and one test of significance, the McNemar, Is used to measure the Impact of S.O.H.C. services.

\section{DESCRIPTIVE DATA UPDATE}

\section{Placement Data}

TABLE XVII shows the types of placements utilized by the s.o.H.C. 
referrals, Lyot all the referrals were placed in S.O.H.C. placements, gone ware placed In R.O.H.C. (Regular Out-of-Home Care) placemente, and others vere not placed in out-of-home care.

\section{TABLE XVII}

OUT-OZ-HOME PLACEMRATS

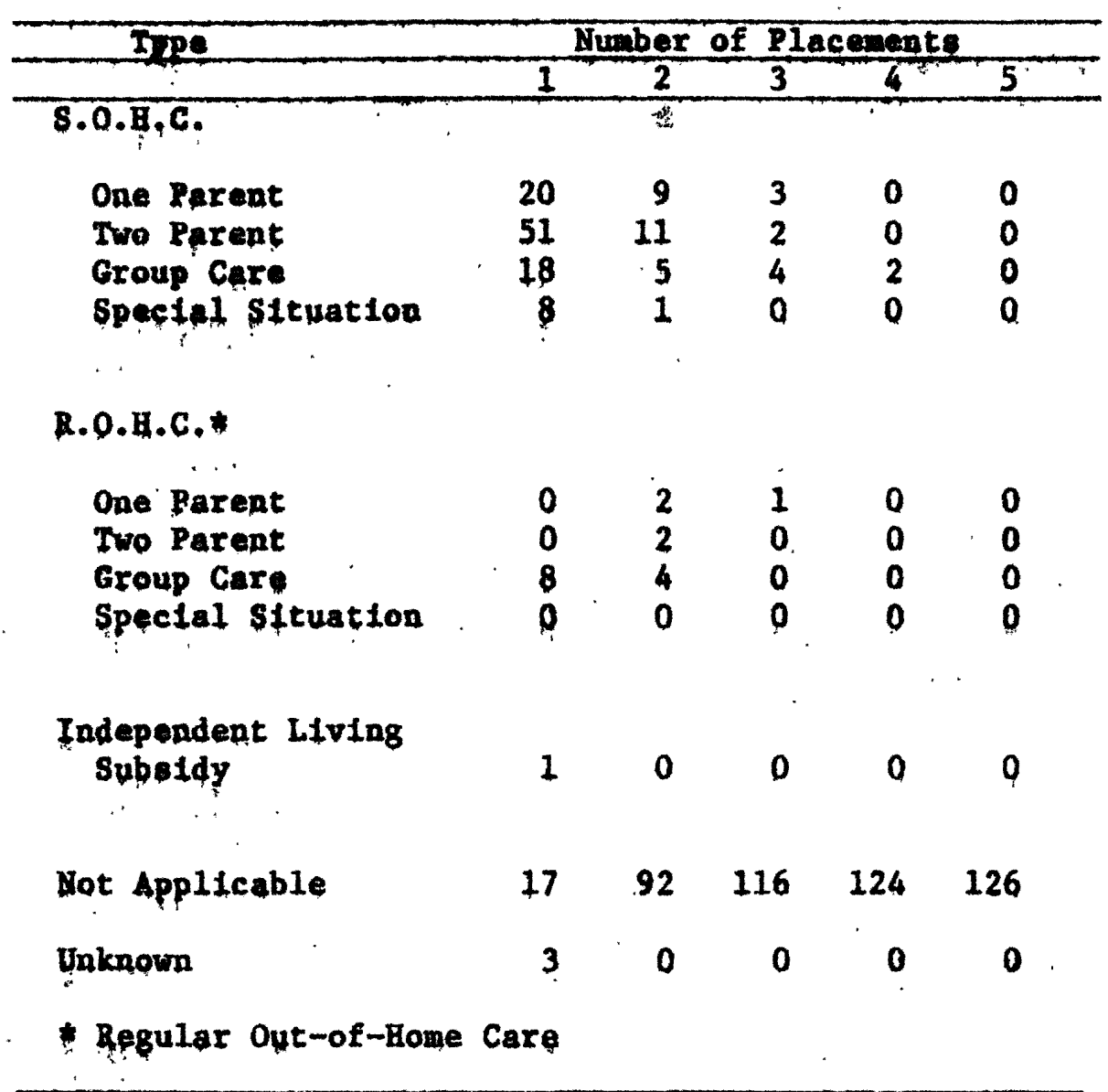

In looking at first placemente, TABLE XVII showe that a total of 98 clients had their first placement with s.O.H.C., Including one client In an fndependent living subsidy. A majority of these clients placed in \$.O.H.C. were living in a family setting with one or two parents $(N=71)$. Group placement ettings were used by 18 s.0.H.C. cllents, and another 
eight in special situations. A small number of first placements $(N=8)$ were made in R.O.H.C. placements. All of these clients vere inltially placed in a group setting. For both S.O.H.C. and R.O.H.C. placements, a total of 21 clients had first placements of two weeks or less.

For second placements, eight clients had an R.O.H.C. setting, half in a group setting and half in a family. Twenty clients had family settings in S.0.H.C. for a second placement, five had group care, and one had a special situation. A total of 92 clients were not placed in a second setting in either S.O.H.C. or R.O.H.C.

TABLE XVIII shows the time spent in placement for both S.0.H.C. and R.O.H.C. clients.

TABLE XVIII

TIME IN PLACEMENT

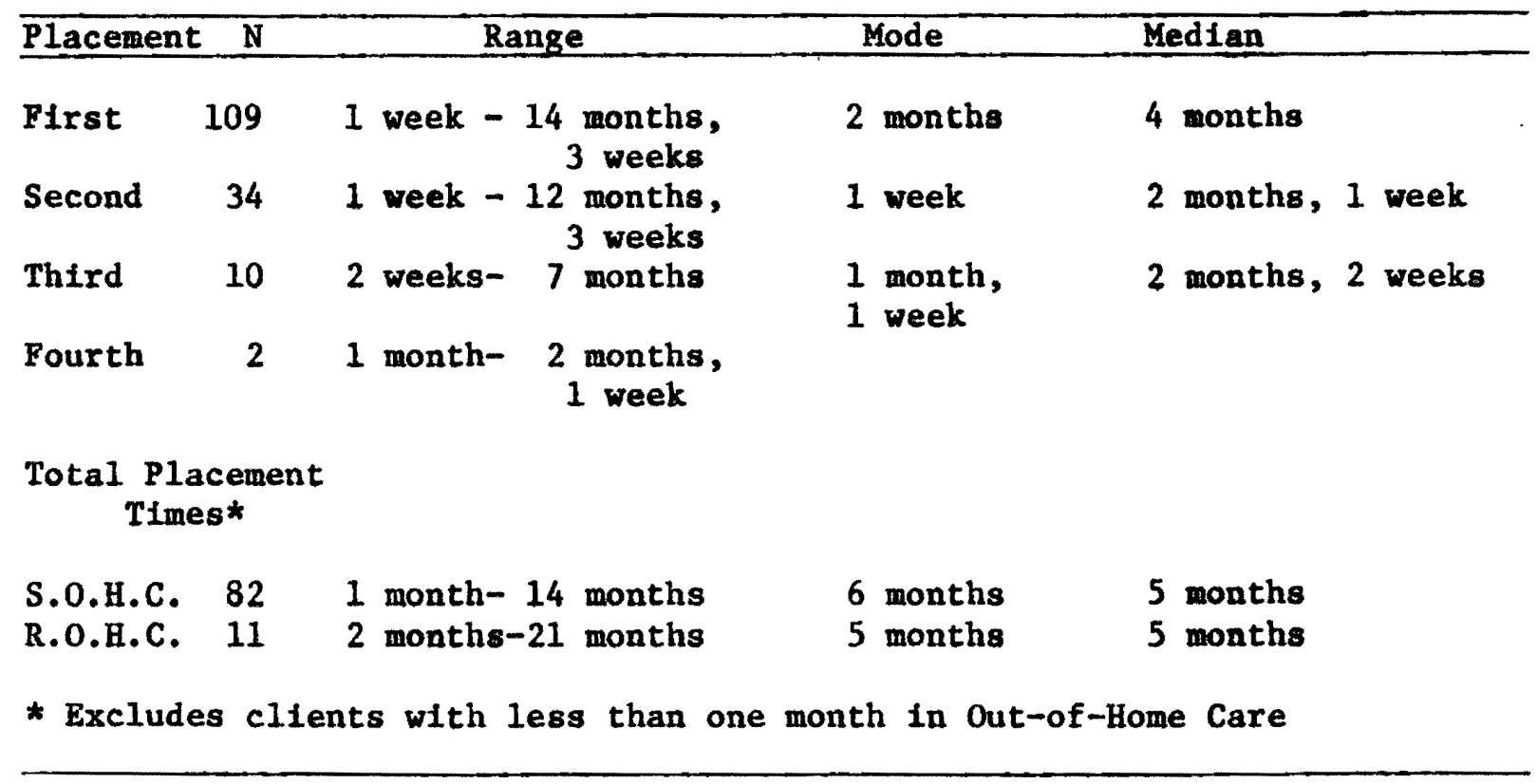

This table shows a wide range of time spent both by S.0.H.C. and R.O.H.C. clients in their placement settings. The least amount of time 
spent is one and two months for S.O.H.C. and R.O.H.C. respectively. The greatest length of stay is seen as being 14 and 21 months for S.O.H.C. and R.0.H.C. clients. TABLE XVIII also shows the median length of stay for S.O.H.C. and R.O.H.C. clients as belng flve months.

TABLE XIX Indicates the length of time the S.0.H.C. referrals spent away from their placement in an institution or on the run.

TABLE XIX

TIME AWAY PROM PLACEMENT

\begin{tabular}{lccccc}
\hline Location & & Range & Mode & Median \\
\hline MacLaren/Hillcrest & 18 & 1 month -11 months & $\begin{array}{c}6 \text { months, } \\
4 \text { days }\end{array}$ & $\begin{array}{c}6 \text { months, } \\
4 \text { days }\end{array}$ \\
On the Run & 21 & 1 day $-\begin{array}{c}4 \text { months, } \\
6 \text { days }\end{array}$ & 2,3 days & 6 days
\end{tabular}

At times S.0.H.C. and R.O.H.C. placements did not work out for some clients. This is reflected to a degree in the number of clients who have run away $(N-21)$ as well as the number of clients who were referred to a more secure institutional setting $(N-18)$ such as Macharen or Hillcrest.

\section{Client's Family}

The update information on the client's family was collected to identify changes occurring within the client's family over time. In the area of changes most needed by parents, the update data was quite similar to that of the data contained on the original Needs Assessment Form completed on each client. A majority of the Case Managers again selected the "Other" category, which represented an individualized "write in" 
response on the questionnaire. Second to this, the change most needed by Mother and Father was in the area of "Resolving own emotional or personal problems."

TABLE XX represents the Case Hanagers' rating of the change in the child/parent relationship for both Mothers and Fathers.

TABLE XX

RATED* CHANGE IN CHILD/PARENT RELATIONSHIP

\begin{tabular}{ccccccc}
\hline Parent & -2 & -1 & 0 & +1 & +2 & Not Applicable \\
\hline Mother & 3 & 9 & 44 & 31 & 14 & 25 \\
Father & 5 & 5 & 35 & 21 & 4 & 56 \\
*Rated by Case Managers & & & & \\
\hline
\end{tabular}

Case Managers rated a major portion of the child/parent relationships as having made no significant changes, $N=44$ and $N=35$ respective1y. More Mothers, however, were rated as having Improved $(N=45)$ than Fathers $(N=25)$. TABLE $X X$ does show a greater representation of Mothers $(N-101)$ than Fathers $(N=70)$ in the rated parent/child ralationships. TABLE XXI shows the current motivation/capacity for change by the Mother/Father as rated by the Case Managers on the update questionnaire.

\section{TABLE XXI}

CURRENT MOTIVATION/CAPACITY TO CHANGE BY MOTHER/FATHER

\begin{tabular}{|c|c|c|c|c|c|c|c|c|c|c|c|}
\hline & $(10 w) 1$ & 2 & 3 & 4 & 5 & 6 & 7 & 8 & $9(\mathrm{~h} 1 \mathrm{gh})$ & Unknown & $\bar{X}$ \\
\hline Mother'\& Motivation & 14 & 20 & 20 & 11 & 15 & 12 & 4 & 4 & 8 & 18 & 4.05 \\
\hline Mother's Capactty & 16 & 17 & 15 & 16 & 15 & 10 & 9 & 5 & 5 & 18 & 4.09 \\
\hline $\begin{array}{l}\text { Father's Motivation } \\
\text { Father's Capacity }\end{array}$ & $\begin{array}{l}18 \\
14\end{array}$ & $\begin{array}{l}7 \\
8\end{array}$ & $\begin{array}{r}11 \\
9\end{array}$ & $\begin{array}{r}9 \\
11\end{array}$ & $\begin{array}{r}9 \\
11\end{array}$ & $\begin{array}{l}8 \\
9\end{array}$ & $\begin{array}{l}5 \\
3\end{array}$ & $\begin{array}{l}1 \\
1\end{array}$ & $\begin{array}{l}5 \\
5\end{array}$ & $\begin{array}{l}53 \\
55\end{array}$ & $\begin{array}{l}3.86 \\
4.00\end{array}$ \\
\hline
\end{tabular}


Compared with the statistics of TABLE XII, TABLE XXI indicates that motivation and capacity for change by Mothers and Fathers have increased over time. The most remarkable change is the mean score found In the Father's capacity to change. This score increased from 3.57 (See TABLE XII) to 4.00. The mean scores for Mother's motivation and capacity for change were found to be 4.05 and 4.09 respectively, while the Father's mean scores for motivation and capacity for change were found to be somewhat lower, 3.86 and 4.00 respectlvely.

\section{Client's Identifled Problem Areas and Motivation/Capactty for Change}

TABLE XXII shows the data update changes in the problem areas of all the referred clients. The total number of 1dentifled clients per problem area (N) and the percentage (\%) of cllents are shown. The Case Managers made these ratings on the update questionnaire in December, 1975.

All but four Identified problem areas did not show any notable change in behaviors. The following three problem behaviors increased in frequency: excessive use of alcohol, from $N=9$ (refer to TABLE XXIII) to $N=24$; pushing drugs at school and in the community, from $N=9$ to $N=12 ;$ and usage of heroin, from $N=0$ to $N=1$. Soclal taboos (public sex play, etc.) stayed constant at $N=4$. There was one dramatic decrease in the identified problem area of theft in neighborhood homes and stores. The frequency of this problem area changed from $N=95$ to $N=60$. 
TABLE XXII

UPDATE DATA ON PROBLEM AREAS OF ALL CLIENTS REFERRED

\begin{tabular}{|c|c|c|c|}
\hline & Problem & $\mathbf{N}$ & $\%$ \\
\hline$\overline{\text { A. }}$ & $\begin{array}{l}\text { BIZARRE BEHAVIORS } \\
\text { 1. Blzarre behavior in community } \\
\text { 2. Social Taboos (public sex play, etc.) }\end{array}$ & $\begin{array}{l}5 \\
4\end{array}$ & $\begin{array}{l}4,0 \\
3.2\end{array}$ \\
\hline$\overline{\text { B. }}$ & $\begin{array}{l}\text { PROPERTY DESTRUCTION } \\
\text { 1. Theft or vandalism of property within school } \\
\text { 2. Destruction of property in the neighborhood } \\
\text { or community } \\
\text { 3. Sets fires in the community } \\
\text { 4. Sets fires in or near home }\end{array}$ & $\begin{array}{r}27 \\
6 \\
3 \\
2\end{array}$ & $\begin{array}{r}21.4 \\
4.8 \\
2.4 \\
1.6\end{array}$ \\
\hline$\overline{c .}$ & $\begin{array}{l}\text { ASSAULT PATTERNS } \\
\text { 1. Fighting physically with peers at school } \\
\text { 2. Physically assaultive to nelghbors, adults, } \\
\text { peers, younger children tn the neighborhood } \\
\text { 3. Physically assaultive to younger siblings } \\
\text { 4. Physically assaultive to older siblings or } \\
\text { those of the same age } \\
\text { 5. Physically assaultive to parents } \\
\text { 6. Physically assaultive to adult school personnel }\end{array}$ & $\begin{array}{l}12 \\
15\end{array}$ & $\begin{array}{r}23.0 \\
19.0 \\
9.5 \\
11.9\end{array}$ \\
\hline
\end{tabular}

D. DRUG/ALCOHOL ADDICTION/HABITUATION

1. Uses Marifuana $\quad 5846.0$

2. Uses other drugs 19.1

3. Excessive use of alcohol $\quad 24 \quad 19.0$

4. Pushing drugs at school or In the community $12 \quad 9.5$

5. Usea heroin

0.0

E. INCORRIGIBILITY AND STATUS OFFENSES

1. Virtually no compliance to parental requests $\quad \begin{array}{lll}47 & 45.2\end{array}$ or Iimits

2. Excessive truancy

3. Non-production at school

$63 \quad 50.0$

4. Refusal to accept/perform routine $\quad 65 \quad 51.6$ responstbilities at home

5. Verbally antagonistic so as to continually $\quad 51 \quad 40.5$ disrupt the family

6. Runaway from home $39 \quad 31.0$

7. Continualiy disruptive to the class at school $22 \quad \begin{array}{ll}17.5 \\ \text {. }\end{array}$

F. THEFT AND EXTORTION

1. Theft in neighborhood homes and stores $\quad 60 \quad 47.6$

2. Stealing from family members $34 \quad 34.0$

3. Extortion at $8 \mathrm{chool}$ from peers $\quad 6 \quad 4.8$ 
The current motivation/capacity for change by the child as rated by the Case Managers on the update questionnalre is shown in TABLE XXIII.

TABLE XXIII

CURRENT MOTIVATION/CAPACITY TO CHANGE BY CHILD

\begin{tabular}{|c|c|c|c|c|c|c|c|c|c|c|c|}
\hline (10 & 1 & 2 & 3 & 4 & 5 & 6 & 7 & 8 & 9(high) & \multicolumn{2}{|l|}{ unknown } \\
\hline Motivation at home & 12 & 14 & 19 & 17 & 25 . & 9 & 15 & 6 & 2 & 7 & 4.32 \\
\hline Capacity at home & 8 & 13 & 11 & 15 & 18 & 16 & 25 & 11 & 2 & 7 & 4.99 \\
\hline Motivation at school & 12 & 14 & 17 & 11 & 22 & 20 & 13 & 5 & 2 & 10 & 4.48 \\
\hline Capacity at school & 7 & 8 & 13 & 6 & 19 & 25 & 20 & 12 & 5 & 11 & 5.32 \\
\hline Motivation in community & 6 & 19 & 14 & 16 & 20 & 18 & 17 & 8 & 2 & 6 & 4.72 \\
\hline Capacity in community & 2 & 9 & 14 & 16 & 18 & 18 & 26 & 12 & 5 & 6 & 5.39 \\
\hline
\end{tabular}

This table shows both the update data on the client's motivation and capacity to change. Compared to TABLE XIV, the child's motivation and capacity for change increased in the following areas: child's mot1vation and capacity for change at home increased from a mean score of 3.67 to a mean score of 4.32 and from a mean of 4.58 to a mean of 4.99 respectively; and child's motivation at school increased from a mean score of 4.03 to a mean score of 4.48 . A decrease was seen in child's capacity at school, from a mean of 5.51 to a mean of 5.32 . Client's motivation and capacity in the community also decreased from a mean score of 4.75 to a mean of 4.72 and a mean of 5.58 to a mean of 5.39 respective1y.

II. COMPARISON OF S.O.H.C. AND NON-S.O.H.C. GROUPS

Percentage Comparison of S.O.H.C. and Non-S.O.H.C. Groups

TABLE XXIV shows the comparison on a percentage basis between the 
S.O.H.C. population and the non-S.0.H.C. population in regards to problem behavior areas. The percentage 1isted on the table are divided into "Before" and "After" columns. The "Before" percentage is taken from the rated behavior problem areas on the Original Needs Assessment Form of each S.0.H.C. and non-S.O.H.C. client. The "After" percentage is taken from the updated Needs Assessment Form questionnaire which was admin1stered to each Case Manager In December, 1975.

The Bizarre Behavior category shows social taboos as being held constant among both the S.Q.H.C. and non-S.O.H.C. groups. B1zarre behavior in the community had a greater "yes" response among the non-S.O.H.C. group. Within the Property Destruction category, setting fires in the community and setting fires in or near the home showed no change in the non-S.0.H.C. group. Destruction of property in the neighborhood or community had a greater decrease in "yes" respondents among the S.0.H.C. group.

Assault Patterns of the S.0.H.C. group showed more improvement than the non-S.0.H.C. group. Physically assaultive to neighbors, adults, peers, younger children in the neighborhood, and physically assaultive to younger siblings showed an observable decrease in the S.o.H.C. group. In the same area, the non-S.O.H.C. group showed a decline which was less dramatic. Physically assaultive to parents showed an Incresse in occurrence among the non-S.0.H.C. population and a decrease in the S.O.H.C. group. The area, physically assaultive to adult school personnel, showed a greater percentage decrease among the non-S.O.H.C. group than in the S.O.H.C. group.

Drug/Alcohol Addiction/Habituation did not show very favorable 
"After" percentages in either group. Uses marifuana and uses other drugs had only a sight decrease for the S.0.H.C. population. An Increase of behaviors were seen in both groups in the area of excessive use of alcohol and pushing drugs at school or In the community. An increase of one client was seen in the S.O.H.C. group with use of heroln. Incorriglbility and Status offenses show a decrease in "yes" responses in all of the seven areas for the S.O.H.C. population. The nonS.O.H.C. population showed an increase in "yes" responses in the areas of refusal to accept/perform routine responsibilities at home and the area of running away from home. A decrease was found in all areas of Theft and Extortion among the S.0.H.C. and non-S.O.H.C. groups. The largest decrease was seen in the area of theft in nelghborhood homes and stores, for both the S.0.H.C. and the non-S.O.H.C. groups. 
TABLE XXIV

COMPARISON OF PERCENT ANSTERING YES TO PROBLEM AREAS

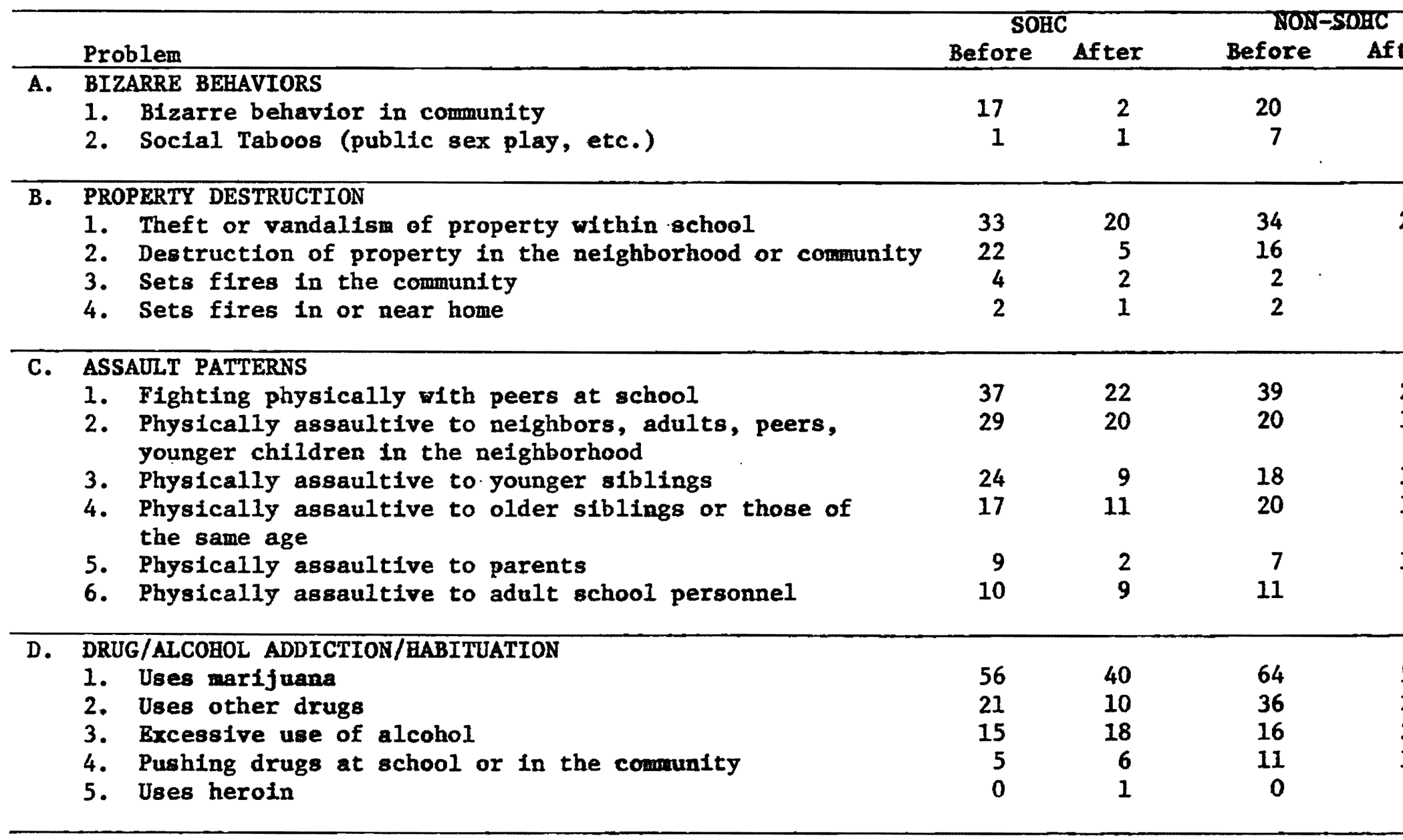


TABLE XXIV (CONTINUED)

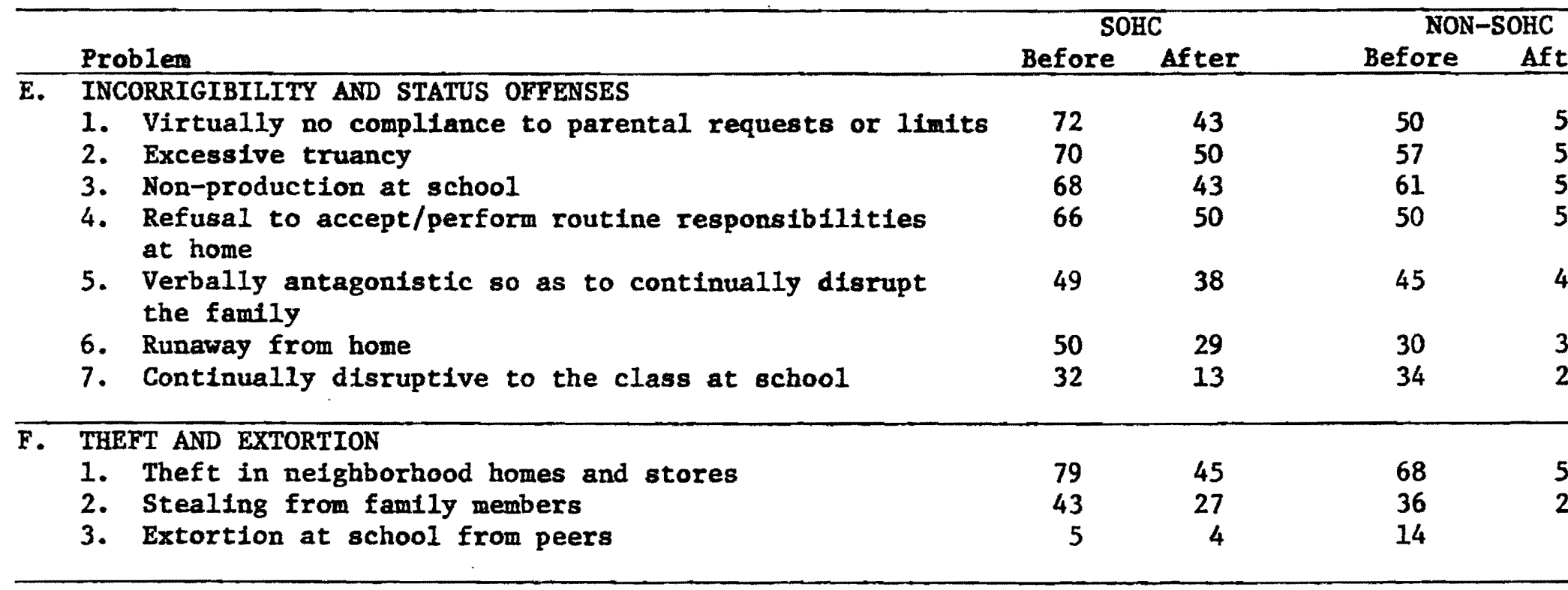


Rated Change in Problem Areas of S.O.H.C. Clients

TABLE XXV indicates the rate of change in the problem areas of the S.0.H.C. clients who were placed solely in s.o.H.C. placements. The degree of rated change in problem area was completed by Case Managers who answered "yes" to the problem as belng current. The -2 to +2 scale is used as a way of rating whether or not the specific problem is worse or better, as a result of time. The "0" signifies no change. This table was complled from the data contained in the update Needs Assessment Form. Prom this table, one can see that the category of Bizarre Behaviors showed a positive change among the s.0.H.C. clients. Within the Property Destruction category, there were four clients who remained without any change in the area of theft or vandalism of property within the school, while 12 improved.

Assault Patterns also had a positive improvement, the greatest being in the physically assaultive to neighbors, adults, peers, younger children in the neighborhood $(N-11)$. Under the Drug/Alcohol Addiction/ Habituation category, a good number of S.0.H.C. clients made improvement. Seventeen of the 33 clients using marijuana decreased their usage, while only two increased. Excessive use of alcohol was another area where there was change for the better. Here nine out of the fifteen Identified S.O.H.C. clients improved over time, and the other six made no change. Incorrigibility and Status offenses also showed improvement over time. Specifically, it was seen that non-production at school had a 1ittle less than one-half (15) of the clients showing improvement, while only three became worse. The category running away from home showed some improvement over time as 12 clients improved and only six became worse. 
TABLE XXV

UPDATE DATA ON PROBLEM AREAS OF SOHC CLIENTS

\begin{tabular}{|c|c|c|c|c|c|c|c|c|}
\hline & & & & Rated & $\overline{C h s}$ & & & \\
\hline & Problem & $\mathbf{N}$ & $\%$ & -2 & -1 & 0 & & \\
\hline A. & $\begin{array}{l}\text { BIZARRE BEHAVIORS } \\
\text { 1. Bizarre behavior in cormunity } \\
\text { 2. Social Taboos (public sex play, etc.) }\end{array}$ & $\begin{array}{l}2 \\
1\end{array}$ & $\begin{array}{l}2 \\
1\end{array}$ & $\begin{array}{l}0 \\
0\end{array}$ & $\begin{array}{l}0 \\
1\end{array}$ & $\begin{array}{l}0 \\
0\end{array}$ & $\begin{array}{l}1 \\
0\end{array}$ & \\
\hline B. & $\begin{array}{l}\text { PROPERTY DESTRUCTION } \\
\text { 1. Theft or vandalism of property within school } \\
\text { 2. Destruction of property in the neighborhood or community } \\
\text { 3. Sets fires in the community } \\
\text { 4. Sets fires in or near home }\end{array}$ & $\begin{array}{r}16 \\
4 \\
2 \\
1\end{array}$ & $\begin{array}{r}20 \\
5 \\
2 \\
1\end{array}$ & $\begin{array}{l}0 \\
0 \\
0 \\
0\end{array}$ & $\begin{array}{l}0 \\
0 \\
0 \\
0\end{array}$ & $\begin{array}{l}4 \\
0 \\
0 \\
0\end{array}$ & $\begin{array}{r}10 \\
2 \\
1 \\
0\end{array}$ & \\
\hline$\overline{c .}$ & $\begin{array}{l}\text { ASSAULT PATTERNS } \\
\text { 1. Fighting physically with peers at school } \\
\text { 2. Physically assaultive to neighbors, adults, peers, } \\
\text { younger children in the nelghborhood } \\
\text { 3. Physically assaultive to younger siblings } \\
\text { 4. Physically assaultive to older siblings or those } \\
\text { of the same age } \\
\text { 5. Physically assaultive to parents } \\
\text { 6. Physically assaultive to adult school personnel }\end{array}$ & $\begin{array}{l}18 \\
16\end{array}$ & $\begin{array}{l}22 \\
20\end{array}$ & $\begin{array}{l}0 \\
0\end{array}$ & $\begin{array}{l}0 \\
0\end{array}$ & $\begin{array}{l}0 \\
4\end{array}$ & $\begin{array}{l}7 \\
3\end{array}$ & \\
\hline$\overline{\mathrm{D}}$. & $\begin{array}{l}\text { DRUG/ALCOHOL ADDICTION/HABITUATION } \\
\text { 1. Uses marijuana } \\
\text { 2. Uses other drugs } \\
\text { 3. Excessive use of alcohol } \\
\text { 4. Pushing drugs at school or in the community } \\
\text { 5. Uses heroin }\end{array}$ & $\begin{array}{r}33 \\
8 \\
15 \\
5 \\
1\end{array}$ & $\begin{array}{r}40 \\
10 \\
18 \\
6 \\
1\end{array}$ & $\begin{array}{l}0 \\
1 \\
0 \\
0 \\
1\end{array}$ & $\begin{array}{l}2 \\
0 \\
0 \\
1 \\
0\end{array}$ & $\begin{array}{r}14 \\
2 \\
6 \\
0 \\
0\end{array}$ & $\begin{array}{r}12 \\
4 \\
8 \\
3 \\
0\end{array}$ & \\
\hline
\end{tabular}


TABLE XXV (CONTINUED)

\begin{tabular}{|c|c|c|c|c|c|c|c|c|}
\hline & & & & Rated & Cha & & & \\
\hline & Problem & $\mathbf{N}$ & $\%$ & -2 & -1 & 0 & & \\
\hline E. & INCORRIGIBILITY AND STATUS OFFENSES & & & & & & & \\
\hline & 1. Virtually no compliance to parental requests or limits & 35 & 43 & 2 & 3 & 9 & & 16 \\
\hline & 2. Excessive truancy & 41 & 50 & 2 & 2 & 14 & & 11 \\
\hline & 3. Non-production at school & 35 & 43 & 1 & 3 & 17 & & 7 \\
\hline & $\begin{array}{l}\text { 4. Refusal to accept/perform routine responsibilities } \\
\text { at home }\end{array}$ & 41 & 50 & 1 & 3 & 12 & & 19 \\
\hline & $\begin{array}{l}\text { 5. Verbally antagonistic so as to continually disrupt } \\
\text { the family }\end{array}$ & 31 & 38 & 0 & 3 & 8 & & 18 \\
\hline & 6. Runaway from home & 24 & 29 & 4 & 2 & 6 & & 7 \\
\hline & 7. Continually disruptive to the class at school & 11 & 13 & 0 & 2 & 5 & & 2 \\
\hline$\overline{\text { F. }}$ & THEFT AND EXTORTION & & & & & & & \\
\hline & 1. Theft in neighborhood homes and stores & 37 & 45 & $\mathbf{0}$ & 3 & 5 & & 13 \\
\hline & 2. Stealing from family members & 22 & 27 & 1 & 1 & 6 & & 10 \\
\hline & 3. Extortion at school from peers & 3 & 4 & $\mathbf{0}$ & 1 & 1 & & 2 \\
\hline
\end{tabular}


Some behavior changes for the better are seen in excessive truancy, refusal to accept/perform routine responsibilities at home and verbally antagonistic so as to continualiy disrupt the family. The last category, Theft and Extortion, showed a positive gain in S.0.H.C. clients, especially within the theft in neighborhood homes and stores area $(N=29)$.

\section{Rated Change in Problem Ares of Non-S.O.H.C. Clients}

TABLE XXVI shows the areas of change among clients who were not placed within S.0.H.C. placements. These non-S.0.H.C. clients came from placements in the R.O.H.C. program, or were not placed in any out-of-home care. This table is similar to the previous table in that the -2 to +2 scale was used as a way of rating whether or not the specific problem was better or worse, as a result of time. The degree of rated change in each problem area was used by Case Managers who answered "yes" to the problem as being current.

Bizarre Behaviors of non-S.O.H.C. cllents had both an increase and a decrease in rated change. Blzarre behavior in the community had a slightly more positive change. Property Destruction behaviors tended to stay either constant or showed improvement. Assault Patterns showed a simflar trend to that of the Property Destruction behaviors. Rated change in these problems remained constant or improved. It is noticed, however, that the areas, physically assaultive to parents and physically assaultive to younger slblings are seen to have grown worse over time. Drug/Alcohol Addiction/Habituation of non-S.O.H.C. clients tends to lean toward a negative rate of change. The area, uses other drugs, is shown to have had only one improvement. The rate of change in Incorrigibility and Status offenses are scattered between a positive and nega- 
tive change. Two areas, virtually no compliance to parental requests or limits $(N=18)$, and refusal to accept/perform routine responsibilities at home $(N-19)$, were seen to have had the most negative change or no change at all.

Theft and Extortion is another category which shows a range of negative and positive behavior changes. Extortion at school from peers did not show any positive rate of change. 
TABLE XXVI

JPDATE DATA ON PROBLEM AREAS OF NON-SOHC CLIENTS

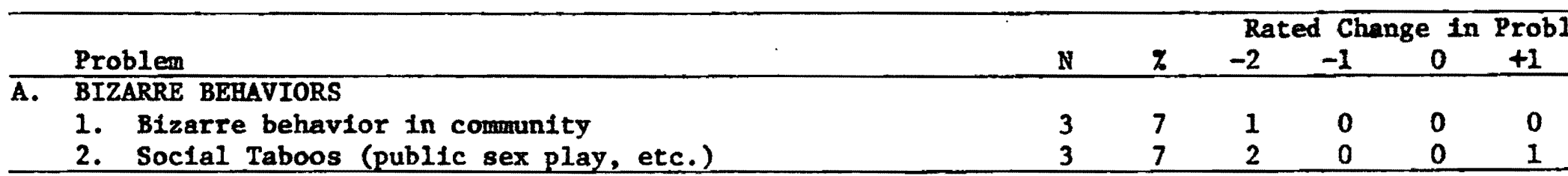

B. PROPERTY DESTRUCTION

1. Theft or vandalism of property within school

2. Destruction of property in the nelghborhood or comanunity

3. Sets fires in the community

4. Sets fires in or near home

\begin{tabular}{rrrrrr}
11 & 25 & 0 & 1 & 4 & 6 \\
2 & 5 & 0 & 0 & 0 & 1 \\
1 & 2 & 0 & 0 & 0 & 0 \\
1 & 2 & 0 & 0 & 1 & 0 \\
\hline
\end{tabular}

C. ASSAULT PATTERNS

1. Fighting physically with peers at school

2. Physically assaultive to neighbors, adults, peers, younger children in the neighborhood

3. Physically assaultive to younger siblings

4. Physically assaultive to older siblings or those of the same age

5. Physically assaultive to parents

6. Physically assault ive to adult school personnel

\begin{tabular}{rrrrrr}
11 & 25 & 0 & 1 & 4 & 4 \\
8 & 18 & 0 & 1 & 2 & 4 \\
5 & 11 & 1 & 2 & 1 & 0 \\
6 & 14 & 0 & 2 & 2 & 1 \\
7 & 16 & 1 & 2 & 3 & 0 \\
2 & 5 & 0 & 0 & 1 & 0 \\
\hline
\end{tabular}

D. DRUG/ALCOHOL ADDICTION/HABITUATION

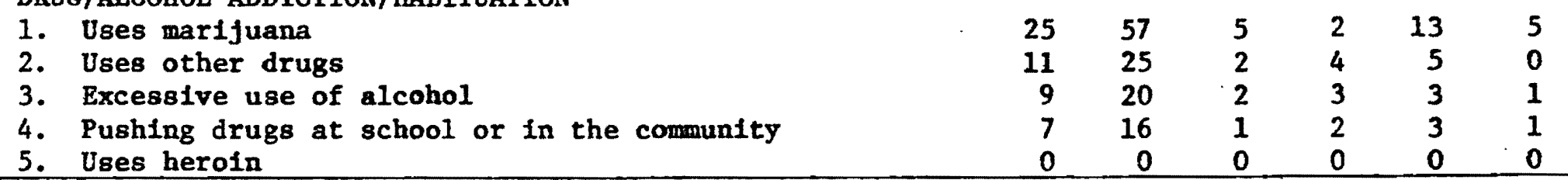


TABLE XXVI (CONTINUED)

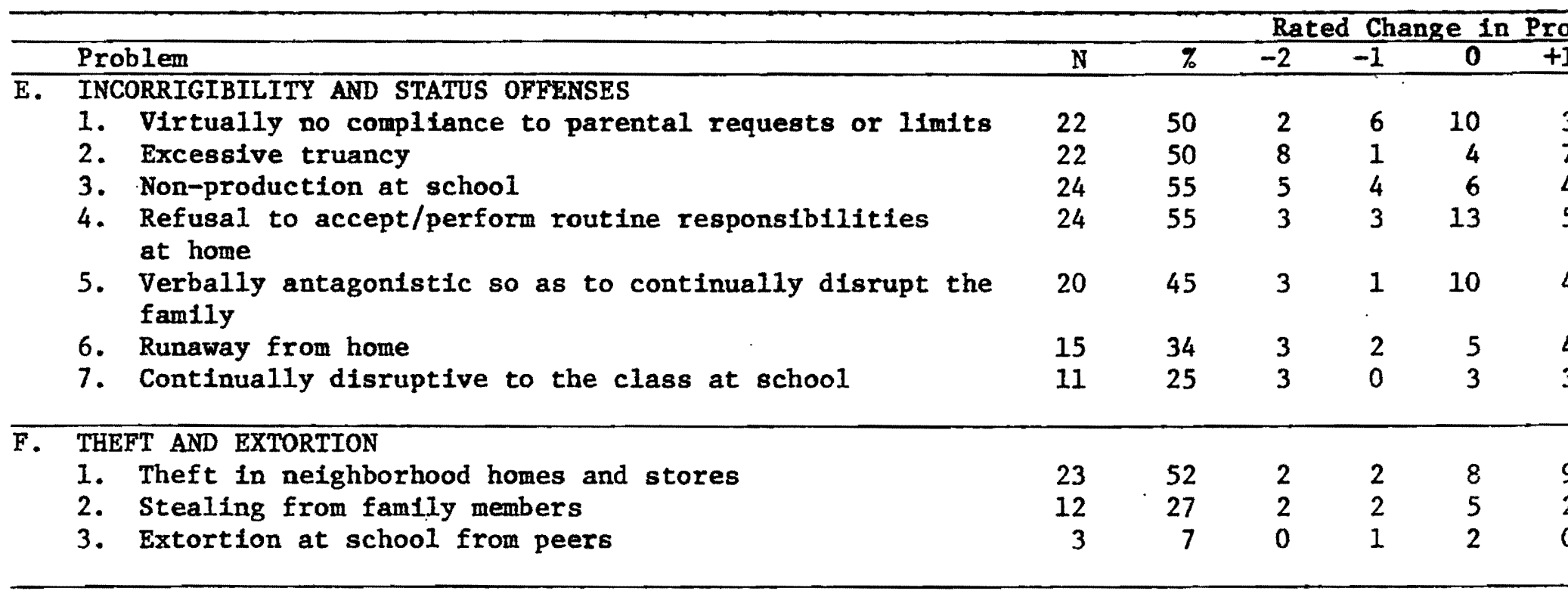


Comparison of Motivation/Capacity to Change Scores

TABLE XXVII shows the mean score on ten motivation and capacity to change 1tems.

TABLE XXVII

MEAN MOTIVATION/CAPACITY TO CHANGE SCORES

\begin{tabular}{|c|c|c|c|c|}
\hline \multirow[b]{2}{*}{ Item } & \multicolumn{2}{|c|}{ SOHC } & \multicolumn{2}{|c|}{ HON-SOHC } \\
\hline & Pre $-\overline{\mathrm{X}}$ & Post $-\bar{X}$ & Pre- $\overline{\mathrm{X}}$ & Post $-\bar{X}$ \\
\hline $\begin{array}{l}\text { Mother's Motivation to Change } \\
\text { Mother's Capacity to Change }\end{array}$ & $\begin{array}{l}4.57 \\
3.90\end{array}$ & $\begin{array}{l}4.47 \\
4.24\end{array}$ & $\begin{array}{l}3.53 \\
3.74\end{array}$ & $\begin{array}{l}3.26 \\
3.82\end{array}$ \\
\hline $\begin{array}{l}\text { Father's Motivation to Change } \\
\text { Father's Capacity to Change }\end{array}$ & $\begin{array}{l}4.02 \\
3.77\end{array}$ & $\begin{array}{l}4.45 \\
4.33\end{array}$ & $\begin{array}{l}3.04 \\
3.14\end{array}$ & $\begin{array}{l}2.81 \\
3.42\end{array}$ \\
\hline $\begin{array}{l}\text { Child's Motivation to Change at Home } \\
\text { Child's Capacity to Change at Home } \\
\text { Child's Motivation to Change at School } \\
\text { Child's Capacity to Change at School } \\
\text { Child's Motivation to Change in the Community } \\
\text { Child's Capacity to Change in the Community }\end{array}$ & $\begin{array}{l}3.75 \\
4.47 \\
4.14 \\
5.64 \\
5.03 \\
6.05\end{array}$ & $\begin{array}{l}4.76 \\
5.34 \\
4.79 \\
5.41 \\
5.10 \\
5.49\end{array}$ & $\begin{array}{l}3.53 \\
4.79 \\
3.83 \\
5.21 \\
4.24 \\
5.57\end{array}$ & $\begin{array}{l}3.59 \\
4.39 \\
3.81 \\
5.17 \\
3.89 \\
5.23\end{array}$ \\
\hline
\end{tabular}

The first four items deal with parents' motivation and capacity scores in each group for both the pre- and post-tests. The mother's motivation to change declined over time in both groups. In the non-S.0.H.C. group the father's motivation declined while it increased for fathers in the S.O.H.C. group. The capaclty scores Improved for both groups over time.

Among the S.O.H.C. clients, mean scores increased over time in all areas except for capacity to change at school and in the community. The non-S.0.H.C. clients had lower means for all items except the child's motivation to change at home, which changed only slightly. 


\section{STATISTICAL ANALYSIS}

The McNemar test was used to measure the significance of change among the S.O.H.C. and non-S.O.H.C. clients and their parents in the areas of: motivation and capacity for mother and father for change, child's motivation and capacity for change, and child's Identified problem areas. The McNemar was chosen because of its abllity to measure over time a rate of change by using a four-square table showing time-1 and time-2 scores. A chi-square formula $\left(x^{2}\right)$ is used to test the significance of each rated time change (See Appendix A for tables).

Nine client problem areas were selected from the S.0.H.C. group ortginal Needs Assessment Form in which $20 \%$ or more of the population responded "yes" in any one problem area. These nine problem areas were compared between the S.O.H.C. and non-S.O.H.C. population. Of these, seven were found to be significantly changed for the S.0.H.C. population. The nonS.0.H.C. cllents showed no behavior changes which reached a level of slgniflcance with the chi-square score.

Behavior areas which showed a significant chi-square level among S.0.H.C. clients were "fighting physically with peers at school" $\left(X^{2}=7.56 ; 1 d . f . ; p=01-.001\right)$, "no compllance to parental requests" $\left(X^{2}=13.23 ; 1 d . f . ; p=.001\right)$, "excessive truancy" $\left(X^{2}=5.60 ; 1 d . f . ; p=.05-.01\right)$, "non-production at school" $\left(x^{2}=10.03 ; 1 d . f . ; p=.01-.001\right)$, "runaway from home" $\left(X^{2}=8.26 ; 1 d . f . ; p=.01-.001\right)$, "continually disruptive to class at school" $\left(X^{2}=12.07 ; 1 d . f . ; p=.001\right)$, and "theft in nelghborhood homes and schools" $\left(x^{2}=19.18 ; 1 d . f . ; p=.001\right)$.

An additional six problem areas were measured with the McNemar for 
solely S.0.H.C. cllents. Corresponding non-S.O.H.C. cllents did not have a large enough response to accurately measure with the McNemar. Those areas found significant in the S.O.H.C. group were "theft or vandaliam of property within school" $\left(X^{2}=4.76 ; 1 d . f . ; p=.05=.01\right)$, "uses marijuana" $\left(x^{2}=10.23 ; 1 d . f . ; p=.05-.01\right)$, "stealing from family members" ( $x^{2}=9.33 ; 1 d . f . ;$ pm.01-.001), "refusal to accept/perform routine responsibilities at home" $\left(x^{2}=4.36 ; 1 d . f . ; p=.05-.01\right)$, and "uses other drugs" $\left(x^{2}=4.90 ; 1 d . f . ; p=.05-.01\right)$. Excessive use of alcohol was tested but was not found to have a significant chi-square.

For both S.O.H.C. and non-S.O.H.C. groups, mother's motivation and capacity for change did not have a significant change when tested by the McNemar. Father's motivation and capacity for change was also found not to show a change of significance at any level for either group.

Child's motivation to change in the home showed a significant change In the S.0.H.C. group $\left(x^{2}=10.02 ; 1 d . f . ; p=.01-.001\right)$. The non-s.0.H.C. group was also tested but was not found to have a significant chi-square. When testing the S.0.H.C. child's capacity for change at home, it showed a chi-square which was close to a significant level. ChIld's motivation and capacity for change at school was not found to reach a significant level for elther the S.O.H.C. or non-S.O.H.C. groups. Child's motivation and capacity for change in the community were also found not to have a significant chi-square for either group.

\section{SUMMARY OF FINDINGS}

The descriptive analysis of the update data shows a majority of s.0.H.C. clients recelving out-of-home care within a one or two parent 
family. R.0.H.C. clients were mostly placed within a group care setting. A client's time spent at his/her initlal placement setting was seen to be an average of five months for both S.O.H.C. and R.O.H.C. Institutional care at MacLaren or Hillcrest had to be used for only a small minority of S.O.H.C. and R.O.H.C. clients.

In the area of changes most needed by parents, the original data and the update data showed no significant changes over times. In other words, parents waintained the same problems Identified by Case Managers when the original Needs Assessment Form was first completed. Case Managers also rated a majority of the child/parent relationships as having made no significant changes over time.

It is interesting to note that motivation/capacity for change by mother and father increased over time. The most observable change was found in the father's capacity to change. Motivation and capacity of the client to change at home also showed a dramatic increase over time. These results tend to indicate that the client and his/her parent showed an improved motivation and capacity to change but parents were not 1ikely to carry through on specific behavioral changes during the measured time lapse.

Problem areas of the S,O.H.C. client showed primarily a decrease in frequency. Out of 27 problem areas, 23 decreased, 1 remained the same, and 3 increased in frequency. The non-S.0.H.C. client population did not change as dramatically in frequency of problem areas. Out of the same 27 problem areas, 16 decreased in frequency, 6 remained the same, and 5 increased in frequency.

The McNemar test was used to measure the significance of the changes 


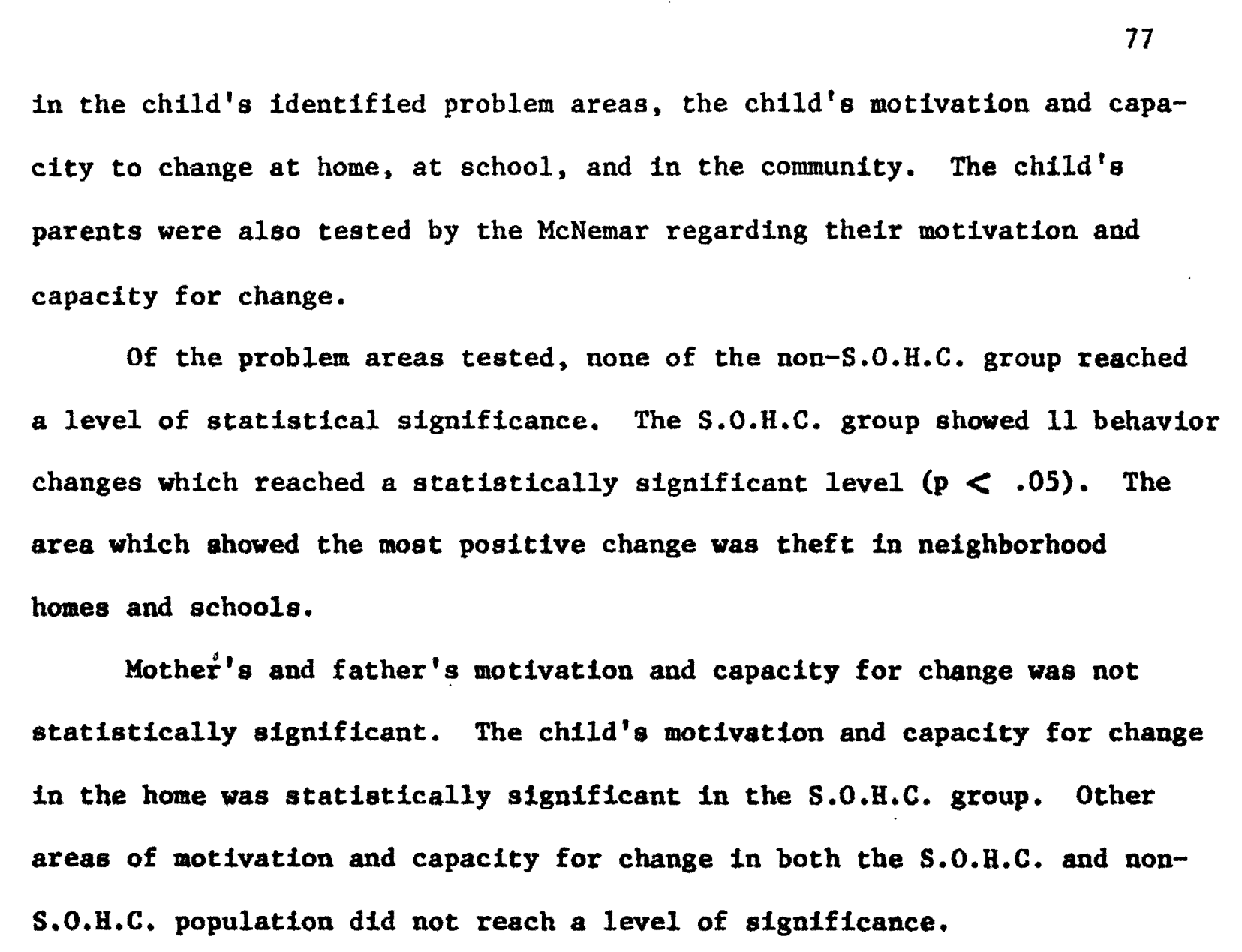




\section{CONCLUSIONS AND RECOMMENDATIONS}

\section{CRITIQUE OF STUDY}

This final chapter will discuss the strengths and weaknesses of the study, review the conclusions, and state the recomendations for future programs and research in this area. Th1s first section will briefly discuss the strengths and weaknesses of the research design and the methodology utilized in this study.

It was beneficial to the researchers that a questionnaire had already been constructed prior to the evaluation of the S.0.H.C. project. This allowed the researchers a pre-test measure that was easily incorporated into the research design. By modifying the Needs Assessment Form to provide a more concise up-date form, the researchers were able to maintain continuity and approximate a pre-test/post-test experimental design. However, it is recognized that the instrument could have been defined more precisely in some of the categories. The Needs Assessment Form could be further modified and defined in the future to provide a more precise evaluation and assessment tool to the Case Managers and resource people.

The sample size was small enough to be manageable and to have data collected on the individual clients within the sample without providing undue stress to the Case Managers. It was large enough to provide a statistically testable population for the researchers. It would have been more beneficial to have had a larger non-S.O.H.C. sample size to enable 
a further, more distinctive, breakdown of this sample group into smaller categories. However, given the limited referrals to various non-S.0.H.C. placements, a larger sample size was not available. In addition, the smallness of the non-S.O.H.C. sample size prohibited some use of the McNemar test for some specific problem areas.

The major criticism that could be made of this study is the subjective nature of the data. The data was gathered from the perceptions of the Case Managers on how the client was dolng instead of relying on observable behavioral data. While the questionnaire tried to get at behavioral measures such as the problem areas, the study still depended on how the Case Managers saw the problem areas and the client's behavior within those areas. Questions such as the motivation or capacity to change are based solely on the Case Manager's impression on how the client or parent was dolng. Although these impressions may be based on observable behavior, there exists the possibility that the Case Managers may portray the clients In the best possible light or credit the client with more capacity or motivation than she/he may have. However, the use of Case Managers as reporting agents can be justifled by a belief in their professional fudgment as well as the fact that they were intensely involved with the clients on their caseload. Such involvement gave them ample opportunity to observe and interpret the client's behaviors.

There was a wealth of data avallable to the researchers in studying the S.0.H.C. project. It is recognized that considerably more data could have been evaluated and studied in depth by the researchers. However, due to time limitations it was necessary to limit the scope of this study. 


\section{CONCLUSIONS AND IMPLICATIONS}

The over-all Impression given by the S.O.H.C. profect is a favorable one. There did seem to be a lessenting of problem behaviors in the S.O.H.C. population. In addition, the child's motivation to change behavior at home increased significantly. The strengths of the S.0.H.C. profect that were reflected in the findings were consistent with the over-all stated objectives. The strengths of the project included: providing professional foster care services to target offenders; matching of providers and clients according to client's needs; Involvement of the client in her/his treatment planning; specialized training for the providers; and support services in the form of relief parenting, additional recreational activities for clients and consultation services. Intensive counseling was provided by the resource developers in the S.O.H.C. project for clients in need of such services. The smaller caseloads of the Case Managers as compared to regular C.S.D. workers also contributed to the individualized attention and support given to the clients. The data seemed to indicate that the individualized attention and the involvement of the client in her/his treatment has had a favorable impact on the client's behavior. A weakness, mentioned by the project people themselves, was the lack of Involvement with the client's parents. This weakness is verifled by the lack of behavior change by the parents in spite of improved motivation to change. The data raises some questions about the S.O.H.C. project and where its efforts are directed. While providing intensive services to the client which have had an impact on her/his problem behaviors (especially with such problems as theft in the community) there has been 1ittle focus on 
the parents themselves. While the parent/child relationships have improved some during the time of the profect, services could have been offered to parents such as parenting classes in child management with oupport and Involvement in the over-all project. The lack of services provided to parents seems to be a result of the over-all design of the project in not bullding such a component into the objectives of the project.

\section{RECOMMENDATIONS}

While the S.O.H.C. project has been beneficial, it is st11l a small-scale, individually oriented, rehabilitation program. One recommendation would be to extend the specialized foster care throughout the entire foster care system to provide these services to all children in need of foster care rather than fust to juvenile target offenders. S1multaneously, broader programs dealing with prevention of juvenile delinquency by Impacting on some of the social causes also need to be conducted and evaluated. More specifically, the S.0.H.C. project should be continued for those clients it does service now, in addition to the continuance of the Case Manager's Correctional Services model with their smaller caseloads and intensified services. These services could also provide more of an emphasis on involvement of the parents in the program. Further evaluations need to be built into these systems to monitor progress and provide feedback on intervention strategies as well as justification for future programs. 
1. Bal1, John and Logan, Ne11, "Early Sexual Behavior of Lower-Class Delinquent Girls", Journal of Criminal Law, Criminology and Police Sclence, Vol. 51, July-August, 1960, pp. 204-214.

2. Bordua, David, "Some Comments on Theories of Group Delinquency", Soclological Inquiry, Vol. 32, Spring, 1962, pp. 249-256.

3. Cloward, Richard and Ohlin, Lloyd, Delinquency and Opportunity, New York: The Free Press, 1960.

4. Cohen, Albert K., Delinquent Boyg, New York: The Free Press, 1955, pp. 25-30, a.

5. Cohen, Albert, "Middle-Class Delinquency and the Soclal Structure", Middle-Class Juvenile Delinquency, New York: Harper and Row, 1967, pp. 242-244, b.

6. Cohen, Albert, "Soclal Control and Subcultural Change", Youth and Society, Vol. 3, March, 1972, pp. 259-276, c.

7. England, Ralph Jr., "A Theory of Middle-Class Juvenile Delinquency", Middle-Class Juvenile Delinguency, New York: Harper and Row, 1967, pp. 242-244.

8. Placks, Richard, Youth and Social Change, Chicago: Markham Publishing Co., 1971.

9. Gemignane, Robert J., "Youth Services Systems", Federal Probation, Vo1. 36, December, 1972, pp. 48-53.

10. Gibbons, Don, Delinquent Behavior: Second Edition, Englewood C11ffs, New Jersey: Prentice-Hall, Inc., 1975.

11. Grossbard, Hyman, "Ego Deficlency In Delinquents", Social Casework, Vol. 43, 1962, p. 3 .

12. Jenkins, Ronald, B., et al., Application for Grant Descretionary Funds, U.S. Department of Justice Law Enforcement Assistance Administration, Children's Services Division, Salem, Oregon, 1974, a.

13. Jenkins, Ronald, B., Project Director, S.0.H.C. Project Quarterly Report, September, 1974-December, 1974, b.

14. Kelley, Delos H. and Pink, Willlam T., "School Commitment, Youth Rebellion, and Delinquency", Criminology, Vo1. 10. February, 1973, pp. 473-486.

15. Kituse, John and Dietrick, William. "Delinquent Boys: A Critique", American Soctological Review, Vol. 24, April, 1959, pp. 208-215. 
16. Lind, Meda Chesney. "Juvenile Delinquency: The Sexualization of Pemale Crime", Psychology Today, Vol. 8, July, 1974, pp. 45-46.

17. Logan, Charles, "Evaluative Research in Crime and Delinquency: A Reappratsal", The Journal of Criminal Law, Criminology and Police Sclence, Vol. 43, 1972, p. 380 .

18. Mech, Edmund. "Delinquency Prevention: A Program Review of Intervention Approaches", A manuscript put out by the Reglonal Research Institute for Human Services, Portland, Oregon, 1975.

19. Nye, F. Ivan. Family Relationships and Delinquent Behavior, New York: John Wiley and Sons, Inc., 1958.

20. Perlman, Richard I. "Antisocial Behavior of the Minor in the United States", Society, Delinquency, and Delinquent Behavior, Boston: Little, Brown and Co., 1970 .

21. Pine, Gerald. "Social Class, Social Mobility, and Delinquent Behavior", The Personnel and Guldance Journal, Vol. 43, Apri1, 1955, pp. $770-774$.

22. Pink, William T. and White, Mervin F. "Delinquency Prevention: A Conference Perspective on Issues and Direction", A manuscript put out by the Reglonal Research Institute on Youth Development and Delinquency Prevention, Portland, Oregon, 1973.

23. Powe11, Hedy-Jo. S.O.H.C. Project Quarterly Report, January 17, 1975, a.

24. Powel1, Hedy-Jo. Project Director. S.0.H.C. Quarterly Report, July, 1975-September, 1975, b.

25. Powel1, Hedy-Jo. "Specialized Out-Of-Home Care Project: Talloring Placements for Target offenders", $c$.

26. Scott, Joseph and Vaz, Edmund. "A Perspective on Middle-Class DeIinquency", Middle-Class Juvenile Delinquency, New York: Harper and Row, 1967, pp. 207-222.

27. Short, James F. and Nye, F. Ivan. "Extent of Unrecorded Juvenile Delinquency: Tenative Conclusions", Journal of Criminal Law, Criminology, and Police Sclence, Vol. 49, November-December, 1958, pp. 296-302.

28. Siegel, Sidney. Nonparametric Statist1cs, New York: McGraw-Hill Book Company, Inc., 1956.

29. Task Force Report: Juvenile Delinquency and Crime, Washington D.C., U.S. Government Printing Office, 1967. 
30. Tate, Rory, Interoffice Memo, Intake Report, July 1, 1975, a.

31. Tate, Rory, S.0.H.C. Project, Intake Report, September, 1975, b.

32. U,S. Department of Justice, Uniform Crime Reports for the U.S., 1973, Washington, D.C.: U.S. Government Printing Off1ce, 1974, p. 119.

33. Willlams, Jay, and Gold, Mart1n. "From Delinquent Behavior to Officlal Delinquency", Soclal Problems, Vol. 20, Fall, 1972, pp. 209-229. 
aONFHD OI LIIIOVAVD/NOILVAIIOW ANV SVAYY

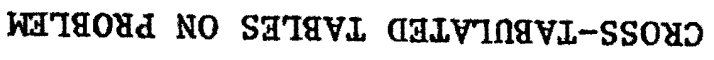

V XIGNGddV 
TABLE XXVIII

ITEM: "FIGHTING PHYSICALLY WITH PEERS AT SCHOOL"

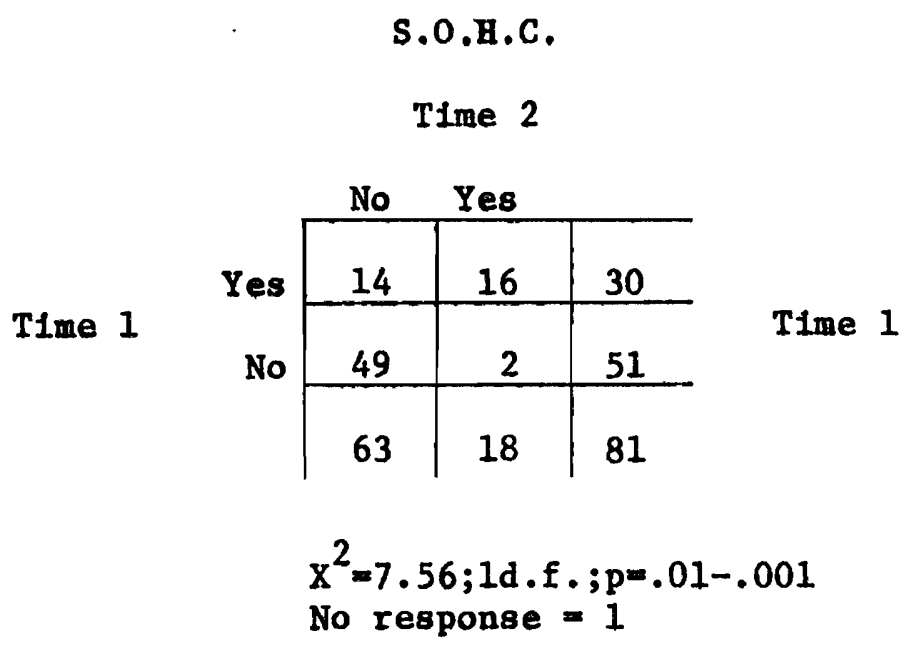

NON-S.O.H.C.

Time 2

\begin{tabular}{c|c|c|c}
\multicolumn{1}{c}{ No } & Yes \\
\cline { 2 - 4 } Yes & 8 & 8 & 16 \\
\cline { 2 - 4 } No & 22 & 3 & 25 \\
\cline { 2 - 4 } & 30 & 11 & 41
\end{tabular}

$x^{2}=1.45 ; 1 d . f . ; n . s$.

No response $=3$

TABLE XXIX

ITEM: "PHYSICALLY ASSAULTIVE TO NEIGHBORS, ADULTS, PEERS, YOUNGER CHILDREN IN NEIGHBORHOOD"

$$
\text { S.O.H.C. }
$$

TIme 2

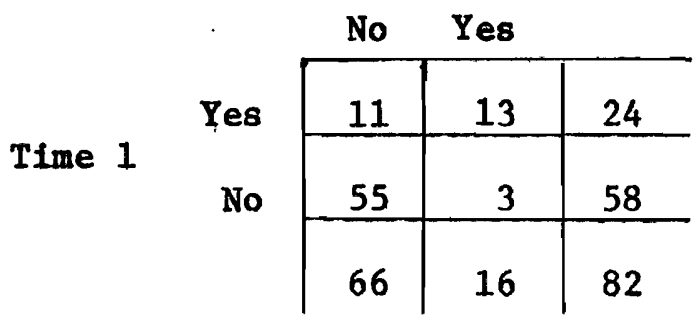

$x^{2}=3.50 ; 1 d . f . ; n \cdot s$. No response $=0$
NON-S . O .H.C.

Time 2

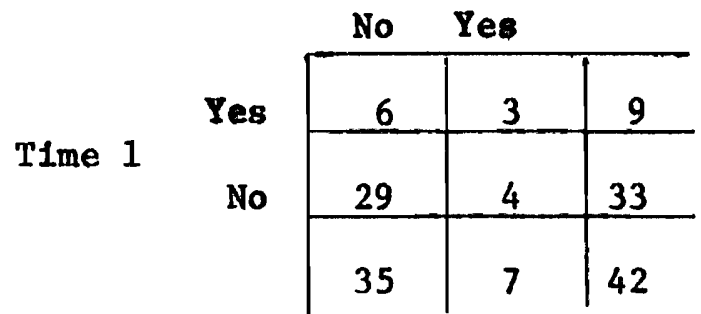

$x^{2}=.1 ; 1 d . f . ; n . s$. No response $=2$ 
TABLE XXX

ITEM: "NO COMPLIANCE TO PARENTAL REQUESTS"

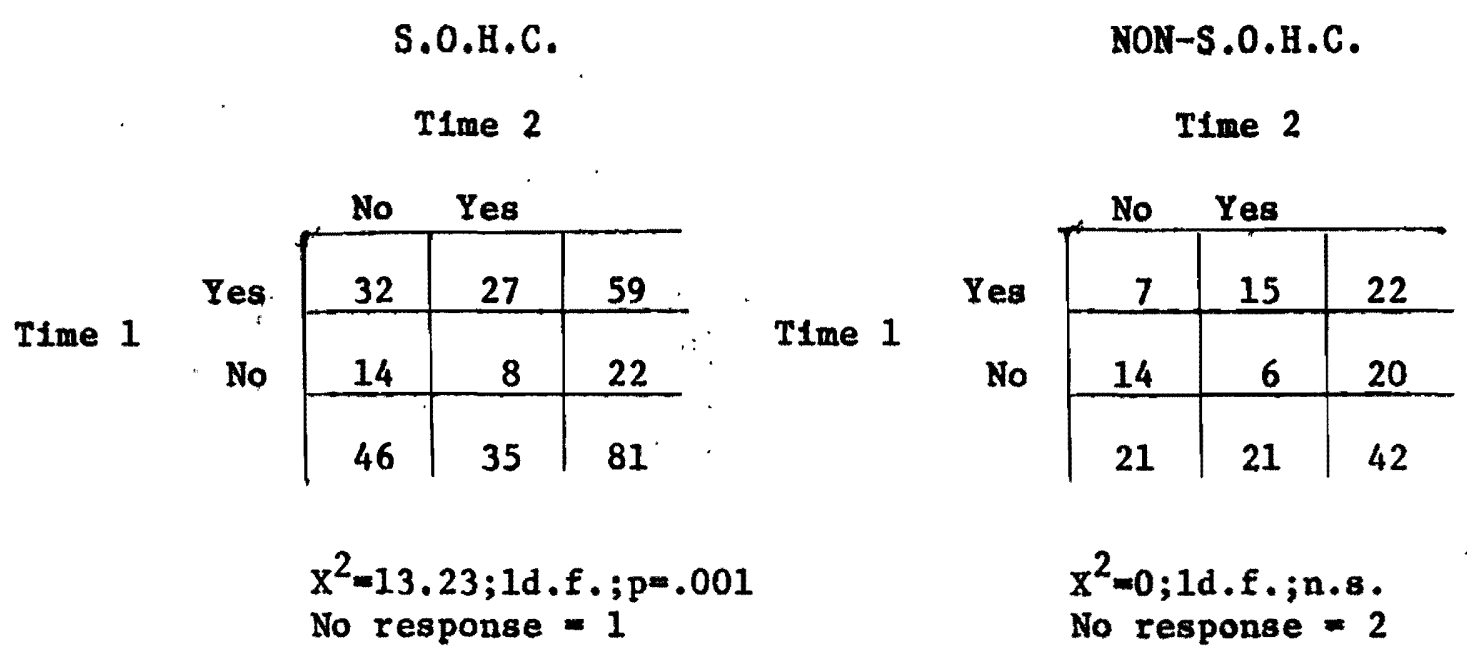

TABLE XXXI

ITEM: "EXCESSIVE TRUANCY"

S.O.H.C.

Time 2

Time 1

\begin{tabular}{c|c|c|c}
\multicolumn{1}{c}{ No } & \multicolumn{2}{c}{ Yes } \\
\cline { 2 - 4 } Yes & 25 & 31 & 56 \\
\cline { 2 - 4 } No & 15 & 10 & 25 \\
\cline { 2 - 4 } & 40 & 41 & 81
\end{tabular}

$x^{2}=5.60 ; 1 d . f . ; p=.05-.01$

No response $=1$
NON-S . O.H.C.

Time 2

\begin{tabular}{|c|c|c|c|}
\hline \multirow{2}{*}{ Yes } & No & Yes & \\
\hline & 9 & 15 & 24 \\
\hline NO & 11 & 7 & 18 \\
\hline & 20 & 23 & 42 \\
\hline
\end{tabular}

$x^{2}=.06 ; 1 d . f . ; n . s$

No response 2 
TABLE XXXII

ITEM: "NON-PRODUCTION AT SCHOOL"

S.O.H.C.

TIme 2

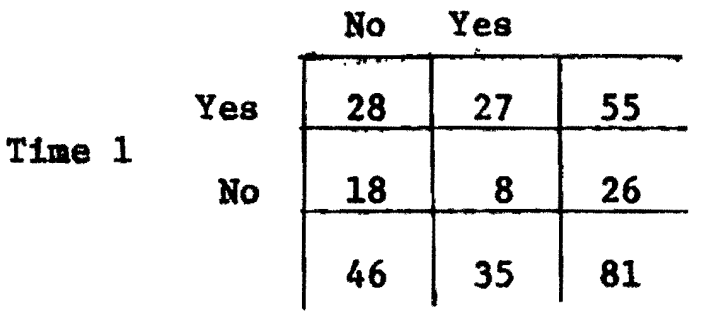

$x^{2}=10.03 ; 1 d . f . ; p=.01-.001$

No response $=1$
NON-S.O.H.C.

Time 2

\begin{tabular}{c|c|c|c}
\multicolumn{1}{c}{ No } & \multicolumn{1}{c}{ Yes } \\
\cline { 2 - 4 } Yes & 8 & 18 & 26 \\
\cline { 2 - 4 } No & 10 & 6 & 16 \\
\hline & 18 & 24 & 42
\end{tabular}

$x^{2}=.07 ; 1 d . f . ; n .8$.

No response $=2$

TABLE XXXIII

ITEM: "VERBALLY ANTAGONISTIC SO AS TO CONTINUALLY DISRUPT THE FAMILY"
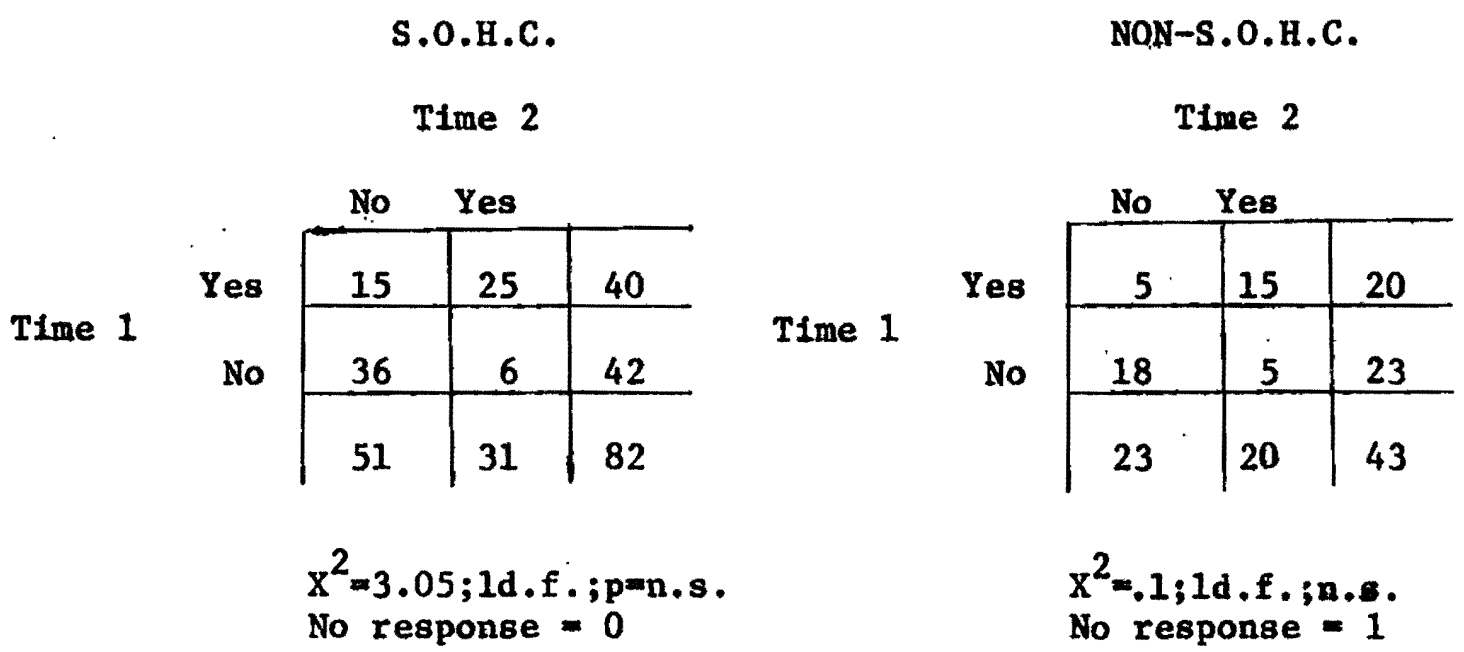
TABLE XXXIV

ITEM: "RUNAWAY FROM HOME"

S.O.H.C.

TIme 2

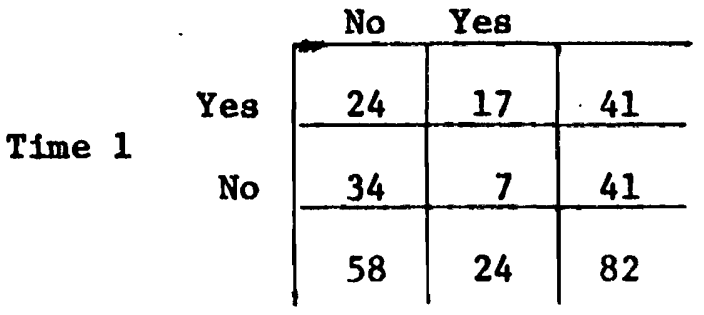

$x^{2}=8.26 ; 1 d . f . ; p=.01-.001$

No response $=0$
NON-S . O.H.C.

Time 2

Yes \begin{tabular}{|r|r|r} 
No & Yes \\
\hline 6 & 7 & 13 \\
\hline 23 & 8 & 31 \\
\hline 29 & 15 & 44
\end{tabular}

$x^{2}=.07 ; 1 d . f . ; n . s$.

No response $=0$

\section{TABLE XXXV}

ITEM: "CONTINUALLY DISRUPTIVE TO CLASS AT SCHOOL"

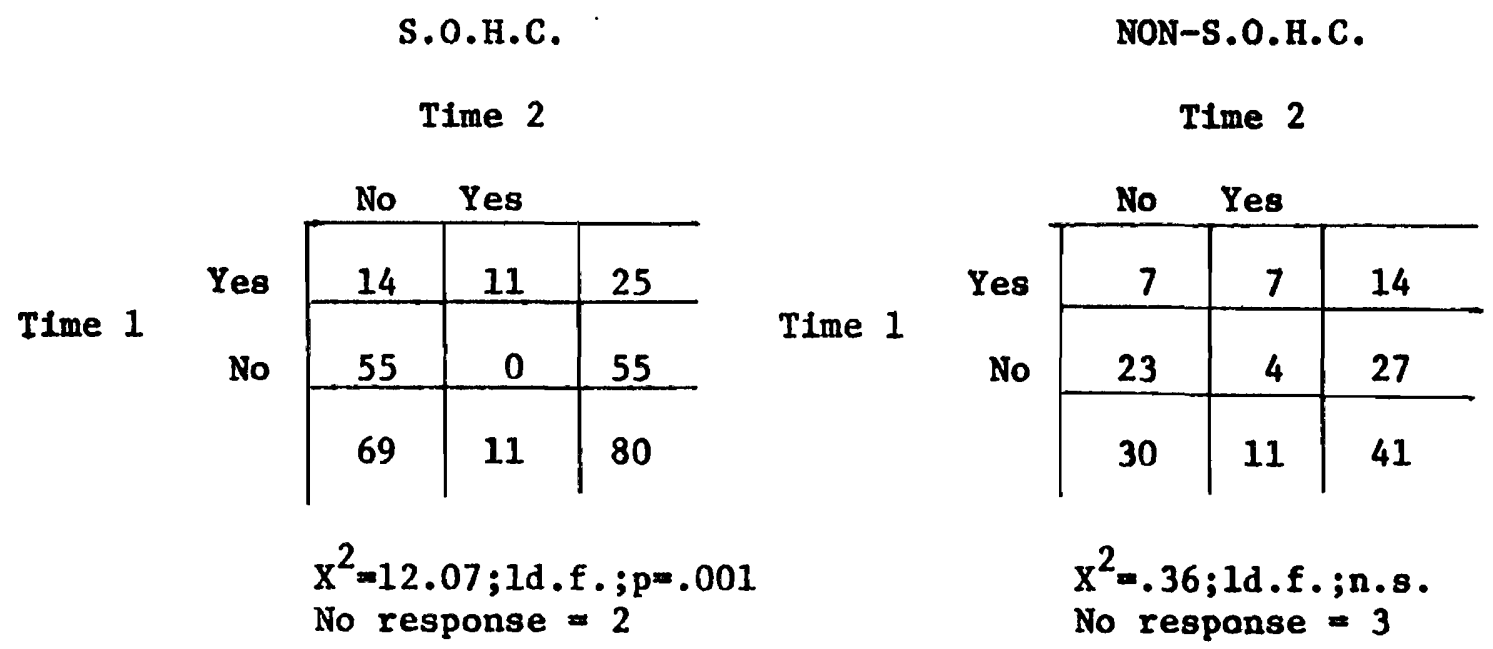


TABLE XXXVI

ITEM: "THEPT IN NEIGHBORHOOD HOMES AND STORES"

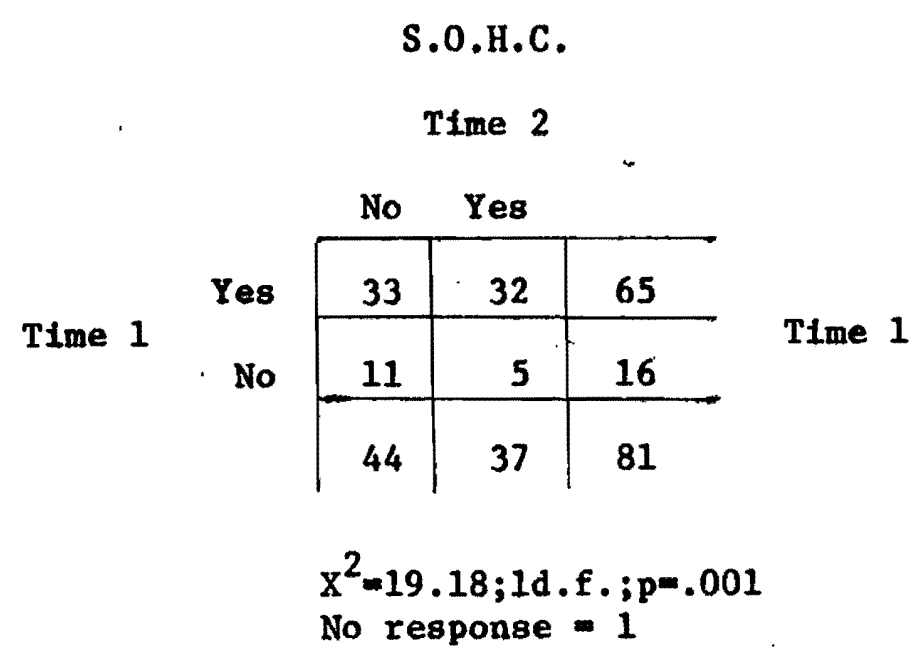

TABLE XXXVII

ITEM: "THEFT OR VANDALISM OF PROPERTY WITHIN SCHOOL"

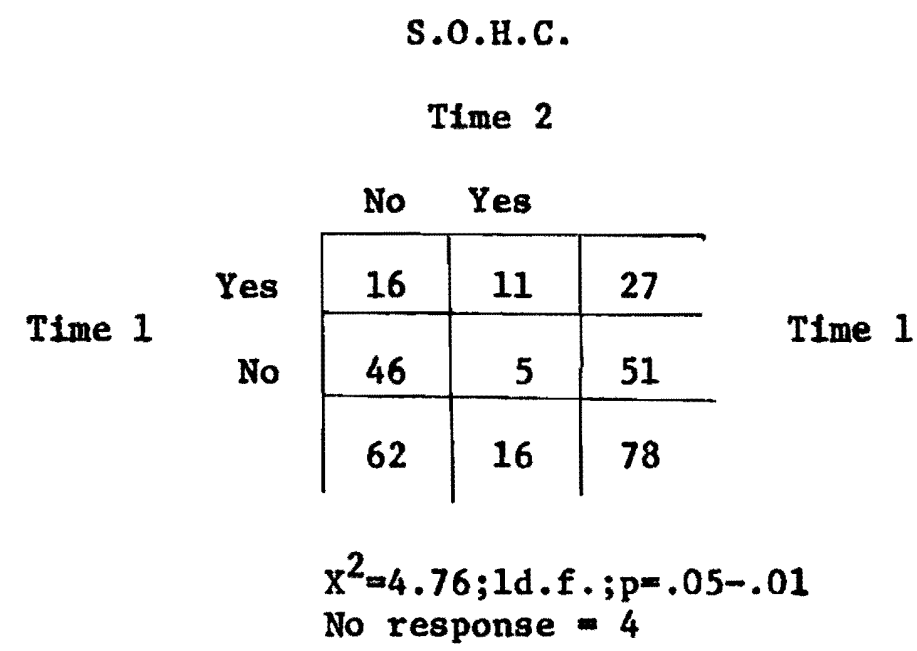

NON-S.O.H.C.
Time 2
Yes \begin{tabular}{|c|c|c} 
No & Yes \\
\cline { 2 - 4 } No & 11 & 30 \\
\hline 9 & 4 & 13 \\
\hline 20 & 23 & 43 \\
& \\
$\mathrm{x}^{2}=2.4 ; 1 d . f . ; n .8$. \\
No response $=1$
\end{tabular}

TABLE XXXVIII

ITEM: "USES MARIJUANA"

S.o.H.C.

Time 2

\begin{tabular}{c|c|c|c|}
\multicolumn{1}{l}{ No } & Yes \\
\cline { 2 - 4 } Yes & 19 & 27 & 46 \\
\hline No & 19 & 3 & 22 \\
\hline 38 & 30 & 68
\end{tabular}

$x^{2}=10.23 ; 1 d . f . ; p=.01-.001$ No response $=14$ 
TABLE XXXIX

ITEM: "USES OTHER DRUGS"

s.o.H.C.

TIme 2

\begin{tabular}{cc|c|c|c|}
\multicolumn{2}{c}{ No } & \multicolumn{2}{c}{ Yes } \\
\cline { 3 - 5 } Time 1 & Yes & 9 & 7 & 16 \\
\cline { 3 - 5 } & No & 48 & 1 & 49 \\
\hline & 57 & 8 & 65
\end{tabular} Time 1

$$
\begin{aligned}
& x^{2}=4.9 ; 1 d . f \cdot ; p=.05-.01 \\
& \text { No response }=17
\end{aligned}
$$

TABLE XILI

ITEM: "STEALING PROM FAMILY MEMBERS"

S.O.H.C.

Time 2

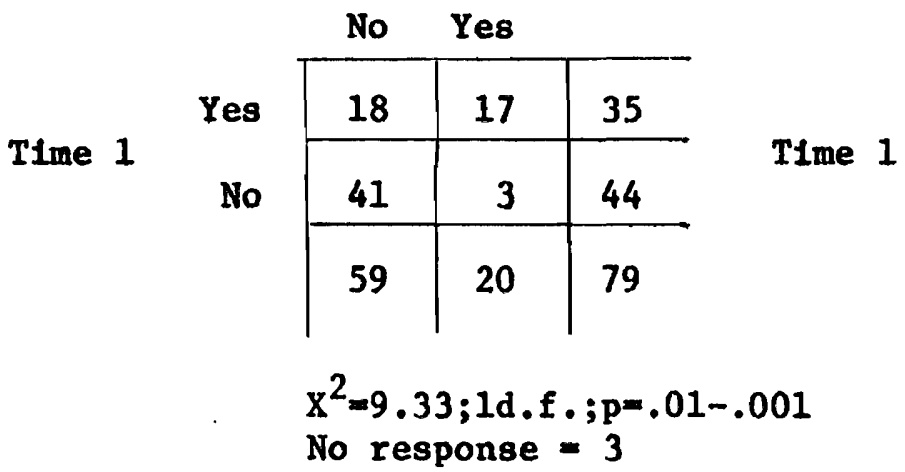

TABLE XI

ITEM: "EXXCESSIVE USE OF ALCOBOL"

S.O.H.C.

\begin{tabular}{|c|c|c|c|}
\hline \multirow[b]{2}{*}{ Yes } & No & \multicolumn{2}{|c|}{ Tes } \\
\hline & 4 & 8 & 12 \\
\hline No & 54 & 7 & 61 \\
\hline & 58 & 15 & 73 \\
\hline
\end{tabular}

TIme 2

$x^{2}=.026 ; 1 d . f . ; n .8$.

No response $=9$
TABLE XIII

ITEM: "REFUSAL TO ACCEPT/PERFORM ROUTINE RESPONSIBILITIES AT HOLE"

S.O.H.C.

\begin{tabular}{|c|c|c|c|}
\hline \multirow[b]{2}{*}{ Yes } & No & \multicolumn{2}{|c|}{ Yes } \\
\hline & 23 & 31 & 54 \\
\hline No & 18 & 10 & 28 \\
\hline & 41 & 41 & 82 \\
\hline
\end{tabular}

TIme 2

$x^{2}-4.36 ; 1 d . f ; ; .05-.01$

No response $=0$ 


\section{TABLE XIIII}

ITEM: "MOTHER'S MOTIVATION FOR CHANGE"

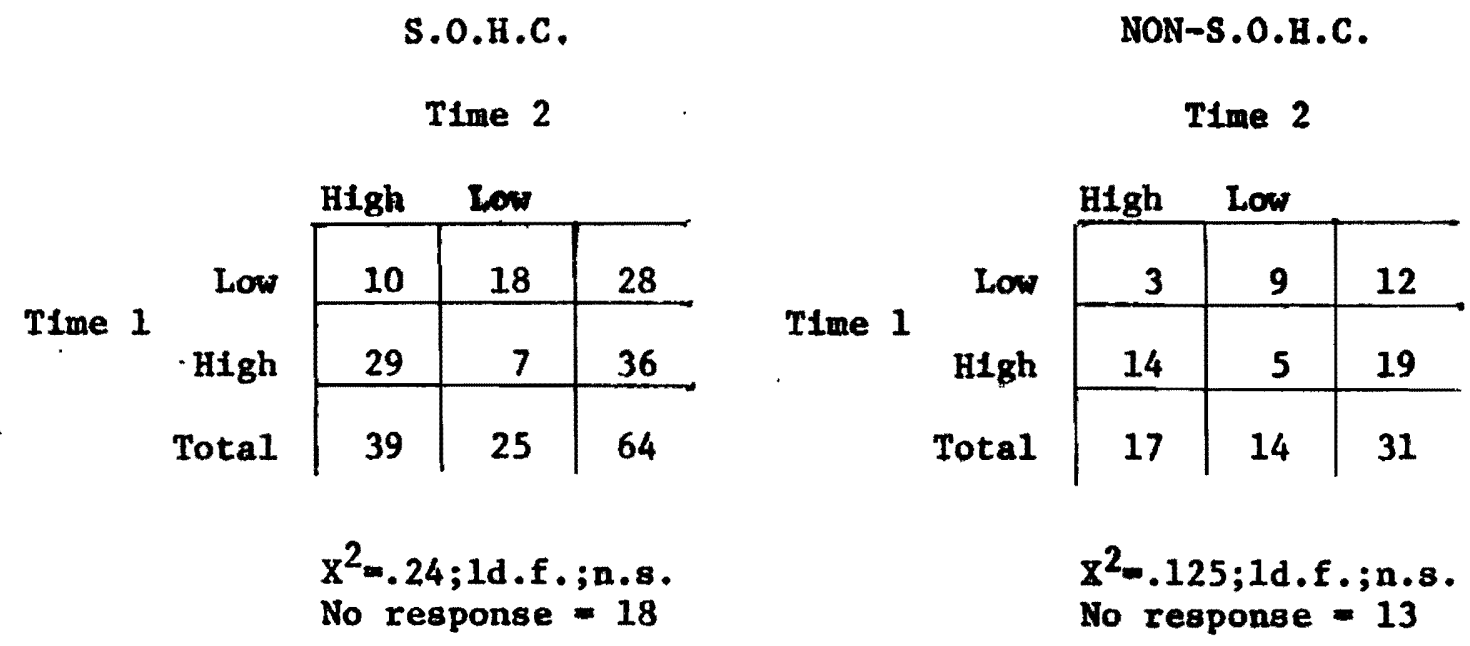

TABLE XILIV

ITEM: "MOTHER'S CAPACITY FOR CHANGE"

S.O.H.C.

Time 2

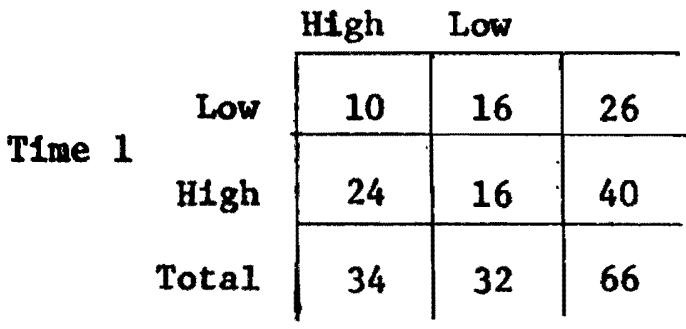

$x^{2}=.96 ; 1 d . f . ; n .8$

No response $=16$
NON-S.O.H.C.

Time 2

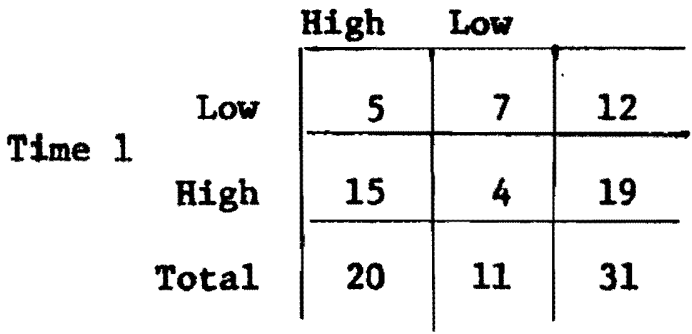

$x^{2}=0 ; 1 d . f . ; n .8$.

No response $=13$ 
TABLE XIV

ITEM: "PATHER'S MOTIVATION FOR CHANGE"

S.O.H.C,

Time 2

\begin{tabular}{rr|r|r|r}
\multicolumn{1}{c}{ High } & \multicolumn{2}{c}{ Low } \\
\cline { 3 - 5 } Time 1 & Low & 4 & 14 & 18 \\
\cline { 3 - 5 } & High & 15 & 8 & 23 \\
\cline { 3 - 5 } Total & 19 & 22 & 41
\end{tabular}

$x^{2}=.75 ; 1 d . f . ; n .8$.

No response $=41$
NON-S.O.H.C.

Time 2

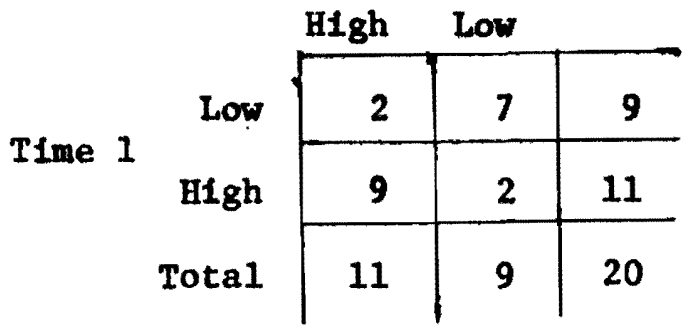

$x^{2}=.25 ; 1 d . f . ; n . s$. No response $=24$

TABLE XLVI

ITEM: "FATHER'S CAPACITY POR CHANGE"

s.о.н.c.

Time 2

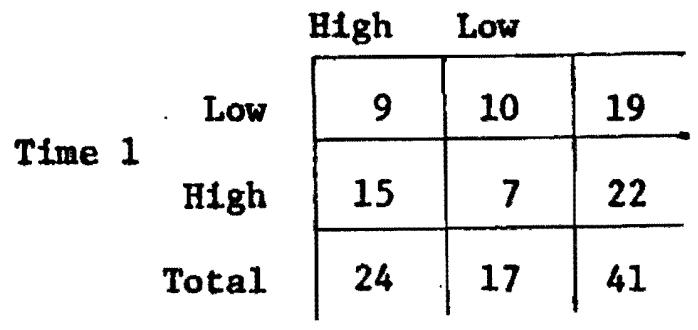

$\mathrm{x}^{2}=.06 ; 1 \mathrm{~d} . \mathrm{f} . ; \mathrm{n} . \mathrm{s}$.

No response $=41$
NON-S.O.H.C.

Time 2

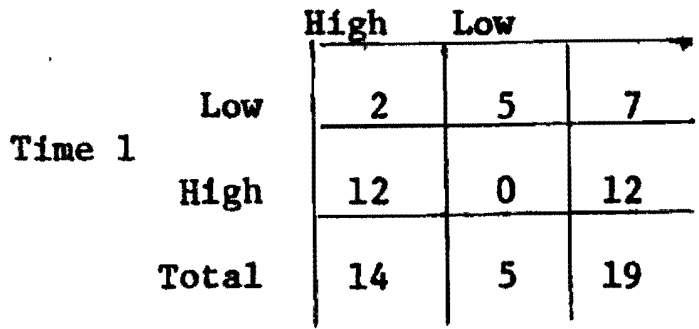

$x^{2}=.50 ; 1 d . f . ; n . s$.

No response $=25$ 
TABLE XIVII

ItEM: "ChILD's motivation to change IN HOME"

S.O.H.C.

Time 2

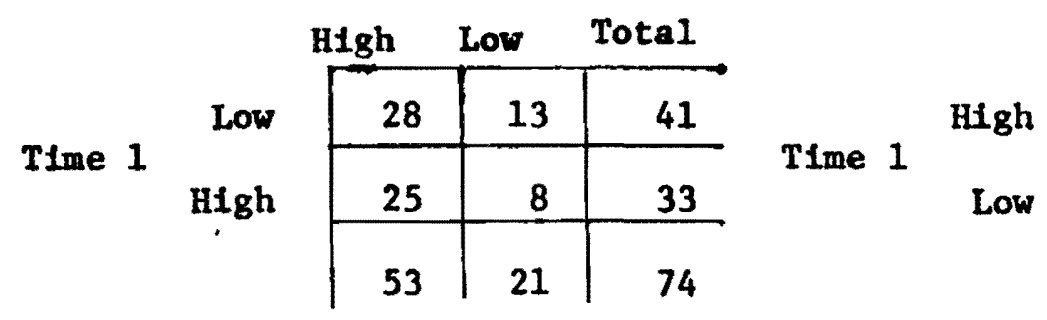

$x^{2}=10.02 ; 1 d . f . ; p=.01-.001$

No response $=8$
NON-S.0.H.C.

Time 2

\begin{tabular}{|r|r|r|} 
H1gh & Low & Total \\
\hline 8 & 17 & 25 \\
\hline 12 & 6 & 18 \\
\hline 20 & 23 & 43 \\
\hline
\end{tabular}

$x^{2}=.07 ; 1 d . f . ; n, s$

No response $=1$

TABLE XIIII

ITEM: "CHILD'S CAPACITY TO CHANGE IN HOME"

S.O.H.C.

Time 2

\begin{tabular}{cc|c|c|c}
\multicolumn{2}{c}{ High } & Low \\
\cline { 3 - 5 } Time 1 & Low & 19 & 7 & 26 \\
\cline { 3 - 5 } & High & 40 & 8 & 48 \\
\cline { 3 - 5 } & & 59 & 16 & 74
\end{tabular}

$x^{2}=3.70 ; 1 d . f . ; n . s$.

No response $=8$
NON-S.O.H.C.

TIme 2

$x^{2}=.30 ; 1 d . f . ; n .8$.

No response $=1$ 
TABLE XLIX

ITEM: "CHILD's MOTIVATION TO CHANGE AT SCHOOL"

S.O.H.C.

Time 2

\begin{tabular}{cc|c|c|c}
\multicolumn{2}{c}{ HIgh } & \multicolumn{2}{c}{ Low } \\
\cline { 3 - 5 } TIme 1 Low & 16 & 10 & 26 \\
\cline { 2 - 5 } & High & 31 & 12 & 43 \\
\hline & 47 & 22 & 69
\end{tabular}

$x^{2}=.32 ; 1 d, f, ; n \cdot s$.

No response $=13$
NON-S.O.H.C.

Time 2

Time 1 Low \begin{tabular}{|c|c|c|c} 
HIgh & Low \\
\hline & High & 12 & 20 \\
\hline 15 & 6 & 21 \\
\hline 23 & 18 & 41
\end{tabular}

$x^{2}=.07 ; 1 d . f . ; n .8$.

No response $=3$

TABLE L

ITEM: "CHILD'S CAPACITY TO CHANGE AT SCHOOL"

S.O.H.C.

TIme 2

High Low

\begin{tabular}{|c|c|c|}
\hline 9 & 6 & 15 \\
\hline 46 & 8 & 54 \\
\hline 55 & 14 & 69 \\
\hline
\end{tabular}

$x^{2}=0 ; 1 d . f . ; n, s$.

No response $=13$
NON-S.O.H.C.

Time 2

High Low

\begin{tabular}{|c|c|c|}
\hline 6 & 4 & 10 \\
\hline 24 & 6 & 30 \\
\hline 30 & 10 & 40 \\
\hline
\end{tabular}

$x^{2}=.08 ; 1 d . f . ; n .8$.

No response $=4$ 
TABLE LI

ITEM: "CHILD'S MOTIVATION FOR CHANGE IN COMMUNITY"

S.O.H.C.

Time 2

High Low

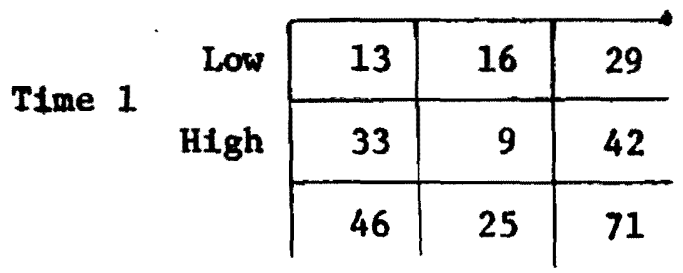

$x^{2}=.40 ; 1 d . f . ; n \cdot s$.

No regponse $=11$
NOS-S.O,H.C.

TIme 2

\begin{tabular}{|c|c|c|c|c|}
\hline & & Lgh & Low & \\
\hline \multirow{3}{*}{ Time 1} & \multirow{3}{*}{$\begin{array}{l}\text { Low } \\
\text { HIgh }\end{array}$} & 4 & 12 & 16 \\
\hline & & 18 & 8 & 26 \\
\hline & & 22 & 20 & 42 \\
\hline
\end{tabular}

$x^{2}=.75 ; 1 d . f . ; n .8$.

No response $=2$

TABLE LII

ITEM: "CHILD'S CAPACITY FOR CHANGE

IN COMMUNITY"

S.O.H.C.

Time 2

High Low

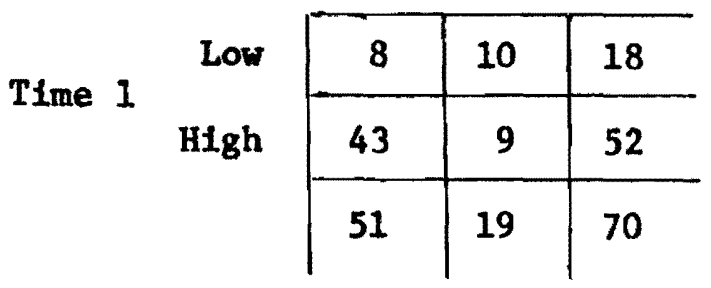

$x^{2}=0 ; 1 d$.f.;n.s.

No response $=12$
NON-S. O.H.C.

Time 2

High Low

Time 1

\begin{tabular}{c|c|c|c}
\multirow{4}{*}{ Low } & & 6 & 10 \\
\cline { 2 - 4 } High & 21 & 11 & 32 \\
\hline 25 & 17 & 42
\end{tabular}

$x^{2}=2.4 ; 1 d . f$. ;n.s.

No response $=2$ 
$\left(0^{\circ} \tau\right)$ \%rOA INGKSSASS Sagan atvad ANY $\left(0^{\circ} \tau\right)$ WROA INAKSSASSY SARAN

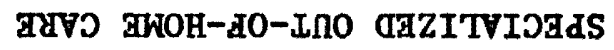

g XIGNIddV 
SPECIALIZED OUT-OF-HOME CARE

NEEDS ASSESSMENT

Form 1.0

\begin{tabular}{ll} 
1. Case Manager $2, \begin{array}{l}\text { Nelghborhood } \\
\text { Office }\end{array}$ \\
3. Client's Name & $\begin{array}{l}\text { CMCS } \\
\text { ID Number }\end{array}$ \\
\hline
\end{tabular}

CHILD IN NEED

5. C11ent's Age 6. Sex 7. Ethnicity

8. Does client or family of cllent have a CSD caseworker?

0 . Unknown

1. Yes

2. No.

9. If you answered yes to above, In what district office is the CSD worker?

0. Not applicable

1. Southeast

2. West

3. East

4. Northeast

5. Model citles

6. Other district

10. Does CSD have temporary custody on this child?

0. Unknown

1. Yes

2. No 
11. Does the child have any physical or mental disability?

0. Unknown

1. Yes

2. No

12. If you answered yes to the above, what is the specific disability?

0. Not applicable

1. Ep1lepsy

2. Speech Impairment

3. Mild mental retardation

4. Other spectfy

13. What is the child's current living situation?

0. Unknown

1. In own family home

2. Out-of-home care

14. If the child is in out-of-home care, where is this?

0. Unknown, not applicable

1. Foster care

2. Child relatives

3. Other specify placement

15. If the child is in out-of-home care, how long has he been in the above placement?

0. Not applicable or unknown

Spectfy number of months

16. Has the child been in previous out-of-home care?

0 . Unknown or not applicable

1. Foster care

2. Child's relatives

3. Other specify placement 
17. What are the number of times the child has been in out-of-home care? Specify number of times

18. How long ago did he leave his most recent out-of-hone placement?

0 . Unknown, not applicable

1. St111 in out-of-home placement

2. Specify number of months up to 12 and if wore than 12 months, spectfy number of years mos. yrs.

19. For up to four previous placements, 11st the number of months lived in each placement, starting with the most recent.

mos.

mos.

mos. mos.

20. Youth's current grade In school. grade level

21. Youth's achievement level in math. grade level

22. Youth's achlevement level in reading. grade level

23. Youth is currently in:

0. Unknown

1. Regular public school

2. Alternative education program

3. Enrolled in (1) or (2) but truant more than one-third of the last year.

4. Not enrolled in any school program 


\section{FAMILY INFORMATION}

1. Parental composition of chlld's family. (Definition:

Parent $=$ One who is doing the parenting).

0. Unknown

1. Two parent family

2. One parent, mother figure

3. One parent, father figure

4. Other composition specify

2. Degree of marital stabilfty of chfld's parent's marriage.

0. Unknown, not applicable

1. Stable

2. Unstable

3. Already dissolved

3. Indicate the parental change most needed to improve parent/ child relationship functioning. (Answer for the mother)

0 . Unknown or not applicable

1. Parent needs to resolve own emotion or personal problems

2. Parent needs to learn or improve disciplinary techniques in order to better control, supervise and structure child's time

3. Parent needs to learn to be consistent in disciplining

4. Parent needs to improve communication and interpersonal relationship with child

5. Parent needs to learn to reward positive behavior

6. Other

describe

4. Indicate the parental change most needed to improve parent/ child relationship functioning. (Answer for the father)

0 . Unknown or not applicable

1. Parent needs to resolve own emotional or personal problews

2. Parent needs to learn or Improve disciplinary techniques in order to better control, supervise, and structure child's time

3. Parent needs to learn to be consistent in discipline 
4. Parent needs to Improve communication and interpersonal relationship with child

5. Parent needs to learn to reward positive behavior

6. Other

describe

5. Mother's motivation to make that change during out-of-home care.

$\begin{array}{llllllllllll}\text { (low) } & 1 & 2 & 3 & 4 & 5 & 6 & 7 & 8 & 9 & \text { (hIgh) clrcle one }\end{array}$

6. Mother's capacity to make that change during out-of-home care. $\begin{array}{llllllllllll}\text { (1ow) } & 1 & 2 & 3 & 4 & 5 & 6 & 7 & 8 & 9 & \text { (hIgh) clrcle one }\end{array}$

7. Father's motivation to make that change during out-of-home care.

$\begin{array}{llllllllllll}\text { (low) } & 1 & 2 & 3 & 4 & 5 & 6 & 7 & 8 & 9 & \text { (high) clrcle one }\end{array}$

8. Father's capacity to make that change during out-of-home care. $\begin{array}{llllllllllll}\text { (low) } & 1 & 2 & 3 & 4 & 5 & 6 & 7 & 8 & 9 & \text { (high) clrcle one }\end{array}$

9. How many children are in the client's family (excluding client)? List actual number

10. How many of these children need intensive services (exclude the client)? 
11. How many of these children needing protective services are recelving it?

0 . Not applicable

1. Two

2. None to two

3. Three to four

4. Five or more

12. How many of these children needing medical services are recelving it?

0 . Not applicable

1. None

2. One to two

3. Three to four

4. Five or more

13. How many of these children needing court counseling are recelving it?

0. Not applicable

1. None

2. One to two

3. Three to four

4. Five or more

14. How many of these children needing residential treatment are receiving it?

0 . Not applicable

1. None

2. One to two

3. Three to four

4. Five or more 


\section{PROBLEA AREAS}

The out-of-home care provided through the SOHC unit is directed at behavior change. This change is deemed necessary for the child's continued stay at his current residence or in preparation for his/ her placement in another setting, whichever is planned for. Without such change, the chlld's return or move CANNor occur. In this context, please indicate the problem behavior for this youth.

Indicate which of all those listed are problems for the child. (Circle response).

1. Runaway from home.

2. Physically assaultive to parents.

3. Physically assaultive to younger siblings.

4. Physically assaultive to older siblings or those of same age.

5. Physically assaultive to adult school personnel.

6. Fighting physically with peers at 8chool.

7. Physically assaultive to nelghbors, adults, peers, younger chlldren in neighborhood.

8. Stealing from family members. yes no

yes no

yes no

yes no.

yes no

yes no

yes no

yes no 
9. Theft or vandalism of property

yes

no

within the school.

10. Theft in nelghborhood homes and

stores.

11. Verbally antagonistic 80 as to continually disrupt the family.

yes

no

12. Virtually no compliance to

yes

no parental request or limits.

yes no

13. Refusal to accept/perform routine responsibilities at home.

14. Extortion at school from peers.

yes

no

15. Excessive truancy.

yes

no

16. Continualiy disruptive to the

no class at school.

17. Non-production at school.

18. Sets fires in or near home.

19. Sets fire in the community. 
21. Pushing drugs at school or in

yes no

the community.

22. Excesstve use of alcohol.

yes no

23. Uses marlfuana.

yes no

24. Uses heroin.

yes no

25. Uses other drugs.

yes

no

26. Bizzare behavior in community.

yes

no

27. Soclal taboos (public sex

yes

no play, etc.)

28. To what extent is the child motivated to change his behavior at home?

$\begin{array}{lllllllllll}\text { (low) } & 1 & 2 & 3 & 4 & 5 & 6 & 7 & 8 & 9 & \text { (hIgh) }\end{array}$

29. What is the child's capactty to change that behavior at home?
(low) 1
2
3
45
67
8 (high)

30. To what extent is the child motivated to change his behavior at school?
(low) 1
2
4
5
7
(high) 
31. What is the child's capacity to change his behavior at school?

$\begin{array}{lllllllllll}\text { (low) } & 1 & 2 & 3 & 4 & 5 & 6 & 7 & 8 & 9 & \text { (high) }\end{array}$

32. To what extent is the child motivated to change his behavior in the community?

$\begin{array}{llllllllllll}\text { (low) } & 1 & 2 & 3 & 4 & 5 & 6 & 7 & 8 & 9 & \text { (hIgh) }\end{array}$

33. What is the child's capacity to change his behavior in the community?

$$
\begin{array}{lllllllllll}
\text { (low) } & 1 & 2 & 3 & 4 & 5 & 6 & 7 & 8 & 9 & \text { (h1gh) }
\end{array}
$$

Please check the appropriate peer group roles which this client might play. Indicate all those appropriate.

leader

planner

dare devil

victimizer

scapegoat

puppet or easy mark

resource man

loyal group member

outcast

loner

tag along yes no

yes no

yes no

yes no

yes no

yes no

yes no

yes no

yes no

yes no

yes no 


\section{PLACEMENT NEEDS}

The SOHC project is designed to develop out-of-home care resources which are needed by Case Management children. To assist in that development, please indicate which resource characteristics would best serve this child.

1. What type of service do you desire from soHC for this client?

1. Placement in existing CSD resource, unspecifled

2. Placement in existing CSD resource specify

3. Placement in a SOHC resource, unspecifled and to be developed

4. Uncertain

2. Why do you wish to make a change of placement for the youth at this time? (indicate only one).

0. Unknown, not applicable

1. Child continually runaway from current placement

2. Child is a serious threat to the safety of others in current placement

3. Child is not benefiting from program at current placement

4. Serious conflict between child and placement provider/ parent (s)

5. Change in child's situation requires child's removal

6. Change in placement's situation requires child's removal

7. Placement provider request child's removal

8. Other reasons

If you do not already have a spectfic existing resource in mind for this youth, would you respond to the following questions, as to what you think might be the most appropriate setting. 
1. Size of placement setting by number of clients served.

(Indicate one only).

0 . Jnknown or not applicable

1. One to three other clients in placement

2. Four to $s i x$ other clients in placement

3. Seven to nine other clients in placement

4. Ten to twenty clients in placement

5. Over twenty cllents in placement

2. Degree of supervision in placement. (Circle appropriate number).

(maximum input

$\begin{array}{lllllllllll}\text { by youth) } & 1 & 2 & 3 & 4 & 5 & 6 & 7 & 8 & 9 & \text { staff control) }\end{array}$

0. For unknown or not applicable

3. Sources of behavioral control for client. (Indicate one only).

0 . Unknown and not applicable

1. Self-control and self-discipline, emphasis on own self responsibility

2. Peer group pressure and control

3. Staff pressure and control

4. General type of placement setting. (Indicate one only).

0 . Unknown or not applicable

1. Family foster home

2. Professionally staffed foster home

3. Group home

4. Small residential treatment center

5. Large residentlal treatment center

6. Institutional setting 
5. Degree of personal freedom permitted youth in placement setting. (Indicate one only).

0 . Unknown or not applicable

1. Youth comes and goes at w111 - complete independence

2. Youth notifies placement provider of whereabouts, but acts Independently

3. Minimal supervision of activities by placement provider

4. Youth keeps to a determined schedule and curfew but his Eree time is his own

5. Keeps to a schedule and curfew and obtains permission on how to spend free time

6. Youth in unlocked setting, but his schedule is primarily determined by the placement provider

7. Youth spends all his time in structured activities although the setting is open and unlocked

8. Youth spends all his time in structured activitles and is under lock up only at night

9. Youth is under twenty-four hours lock up

6. Treatment approach to be used to change youth's behavior in placement. (Indicate one only).

0 . Unknown or not applicable.

1. Traditional, formal psychiatric treatment

2. Counseling, insight therapy

3. Behavior modification approach - cause and effect

4. Learning approach - train in basic societal skills so youth can make it

5. Reality therapy

6. Milieu therapy

7. Guided group interaction

8. No particular therapeutic approach, just warmth and affection

9. Other specify

7. Location of placement. (Indicate one only).

0 . Unknown or not applicable

1. Within the child's immediate neighborhood

2. Within same community (S.E. Portland, N.E. Portland, etc.)

3. Across town or in surrounding Portland area

4. In a distinctly rural area

5. In another area of the state a considerable distance from Portland

6. Other specify 
8. Type of education program needed by child in placement. (Indlcate one only).

0. Unknown or not applicable

1. Educational program operating within the out-of-home care facility

2. Specially designed school but operating outside the factlity

3. Use community based alternative education programs

4. Use local public schools

5. Other specify

9. Educational areas needing stress with youth during placement. (Circle all applicable).

0 . Unknown or not applicable

1. Basic academic skills

2. Vocational skills

4. Survival skills

8. Other specify

10. Is it a part of your case plan that this child will return to his/her family following out-of-home care?

0. Unknown

1. Yes

2. No

\section{OTHER CLIENT INFORMATION}

Please Indicate the types of recreational activities the youth enjoys. (Mark all applicable).

1. Strenously physical yes no

2. Competitive against self yes no

3. Competitive against peers yes no

4. Competitive against adult yes no

5. Use of fine motor skills yes no 
6. Construction

7. Spectator or receptor activities

8. Service

9. Expressive

10. Self-development yes no

yes no

yes no

yes no

yes no

Please Indicate the child's strengths. (Mark all applicable).

1. Good sense of humor-(able to yes no laugh at self)

2. Initlates activities (self-starter) yes no

3. Creative thinker yes no

4. Good 11stener yes no

5. Good talker (knows art of self- yes no expression)

6. Optimistic outlook on life yes no

7. Insightful into own and others yes no behavior

8. Responds positively to those yes no who try to "help"

9. Falr degree of emotional yes no control

10. Catches on quickly yes no

11. Other qualities describe 
Does the child have spectal talents or abilities which could be further developed? (Note all applicable).

1. Mustcal

2. Athletic

3. Dramat1c

4. Mechanical

5. Art/Craft

6. Creative writing

7. Interest in animals

8. Interest in growing things

9. Other talents yes no

yes no

yes no

yes no

yes no

yes no

yes no

yes no 
SPECIALIZED OUT-OF-HOME CARE

NEEDS ASSESSMENT

Form 1.0

(Update)

Note: This special version of the SOHC Form 1.0 1s to be re-admintstered to CMCS Case Managers for all cllents referred to the SOHC project during Fiscal Year 1975 (July 1, 1974 through June 30, 1975) regardless of whether or not the SOHC project placed them in speclalized (SOHC) placements, channeled them to CSD for regular outof-home care, or made no out-of-home care placement to the present. THE PURPOSE OF THIS FORM IS TO UPDATE INFORMATION ON THE ORIGINAL FORM 1.0 AND PROVIDE A VEHICLE FOR REPORTING POSITIVE OR NEGATIVE CHANGES OCCURRING IN THE CLIENT'S BEHAVIORS AND ATTITUDES OVER TIME.

1. Case Manager completing original form

2. Case Manager completing this form

3. Neighborhood office

4. CLIENT'S NAME

CMCS

ID Number

aka Name SOHC ID Number

CHILD IN NEED

5. Client's Age 6. Sex 7. Ethnfe1ty

\section{PLACEMENT INFORMATION}

From the time you first referred this child to soHC for out-of-home care placement to the present, please summarize each out-of-home care placement by checking all Information which applies. (Do not Include informal placements with relatives, etc.)

6. Was there at least one out-of-home care placement arranged by SOHC during the above perlod?

Yes No

7. If you answered "YES" above, summarize each out-of-home care placement by checking all items which apply: 
A. First Placement

(a) Type:

Speclalized (SOHC) out-of-home placement with project

Regular (CSD) out-of-home placement via channeling to CSD

(b) Setting: One parent foster care Independent living subsidy Two parent foster care Group care Special Situation

(c) Total time in above placement in months and weeks: Months Weeks

B: Second Placement

(a) Type: Specialized (SOHC) out-of-home placement with project Regular (CSD) out-of-home placement via channeling to CSD

(b) Setting: One parent foster care Two parent foster care Group Care Independent living subsidy Special Situation

(c) Total time in second placement in months and weeks: Months Weeks

\section{c. Third Placement}

(a) Type: Specialized (SOHC) out-of-home placement with project

Regular (CSD) out-of-home placement via channeling to CSD

(b) Setting: One parent foster care Independent living subsidy Two parent foster care Group Care Special Situation 
(c) Total time in third placement in months and weeks: Months Weeks

D. Fourth Placement

(a) Type: Speciallzed (SOHC) out-of-home placement with project

Regular (CSD) out-of-home placement via channelling to CSD

(b) Setting:

One parent foster care
Two parent foster care
Group Care
Independent living subsidy

(c) Total time in fourth placement in months and weeks: Months Weeks

E. Fifth Placement

(a) Type: Speclalized (SOHC) out-of-home placement with project

Regular (CSD) out-of-home placement via channeling to CSD

(b) Setting: One parent foster care Two parent foster care Group Care Special Situation

One parent foster care $\quad$ Independent
Two parent foster care
Group Care

(c) Total time in fifth placement in months and weeks: Months Weeks

F. S1xth Placement

(a) Type: Speclalized (SOHC) out-of-home placement with project

Regular (CSD) out-of-home placement via channeling to CSD 
(b) Setting:

One parent foster care

Independent

IIving subsidy

Two parent foster care

Group Care

Special S1tuation

(c) Total time in sixth placement in months and weeks:

Months Weeks

G. Seventh Placement

(a) Type: Specialized (SOHC) out-of-home placement with project

Regular (CSD) out-of-home placement via channeling to CSD

(b) Setting: One parent foster care

Independent Two parent foster care living subsidy

Two parent foster care
Group Care
Special Situation

(c) Total time in seventh placement in months and weeks:

Months Weeks

(Do not write in this space)

Totals: Type

Setting

Time

Delete Items $8-11$

12. For the above period was this child ever in Mclaren/Hillcrest (institutionalized)? Yes No

If yes, for how long: Months Weeks Days

13. For the above perlod was this ch1ld ever "on the run" (A.W.O.L.)?

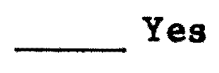
No Does not apply (child institutionalized)

If yes, for how long: Months Weeks Days 


\section{FAMILY INPORMATION}

(Definition: Parent $=$ One who is doing the parenting.)

1. Parental composition of child's family (current).

0. Unknown

1. Two parent family

2. One parent, mother figure

3. One parent, father figure

4. Other composition, spectfy

2. Current degree of marital stability of child's parent's marriage.

0. Unknown, not applicable

1. Stable

2. Unstable

3. Already dissolved

3. Indicate the parental change currently most needed to Improve parent/child relationship functioning. (Answer for the mother)

0 . Unknown or not applicable

1. Parent needs to resolve own emotional or personal problems

2. Parent needs to learn or Improve disciplinary techniques in order to better control, supervise and structure child's time

3. Parent needs to learn to be consistent in disciplining

4. Parent needs to Improve communication and Interpersonal relationship with child

5. Parent needs to learn to reward positive behavior

6. Other

describe

4. Indicate the parental change currently most needed to improve parent/child relationship functioning. (Answer for the father)

0 . Unknown or not applicable

1. Parent needs to resolve own emotional or personal problems

2. Parent needs to learn or improve disciplinary techniques in order to better control, supervise and structure child's time

3. Parent needs to learn to be consistent in discipline

4. Parent needs to Improve communication and Interpersonal relationship with child

5. Parent needs to learn to reward positive behavior 
6. Other

describe

5. In comparison to the time when this child was first referred (date of first Form 1.0 Needs Assessment), rate the child/ parent relationship functioning. (Do this first for the Mother)

0 . No need for change or "does not apply." (Leave Blank)

1. Rate change as follows (See scale):
$-2$
$-1$
0
$+1$
$+2$

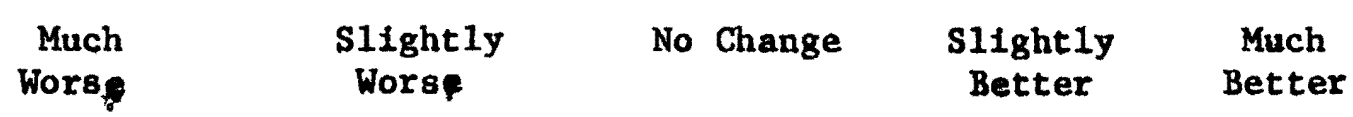

6. In comparison to the time when this child was first referred (date of first Form 1.0 Needs Assessment), rate the child/ parent relationship functioning. (Do this for the Father)

0 . No need for change or "does not apply." (Leave Blank)

1. Rate change as follows (See scale above):

$\begin{array}{llllll}-2 & -1 & 0 & +1 & +2\end{array}$

7. Mother's motivation (currently) to make change(s) in \#3 above. $\begin{array}{llllllllllll}\text { (low) } & 1 & 2 & 3 & 4 & 5 & 6 & 7 & 8 & 9 & \text { (hIgh) } & \text { Clrcle one }\end{array}$

8. Mother's capacity (currently) to make change(s) in $\$ 3$ above. $\begin{array}{llllllllllll}\text { (1ow) } & 1 & 2 & 3 & 4 & 5 & 6 & 7 & 8 & 9 & \text { (high) Circle one }\end{array}$

9. Father's motivation (currently) to make change(s) in \#4 above. $\begin{array}{lllllllllll}\text { (1ow) } & 1 & 2 & 3 & 4 & 5 & 6 & 7 & 8 & 9 & \text { (hIgh) }\end{array}$

10. Father's capac1ty (currently) to make change (s) in $\$ 4$ above. $\begin{array}{llllllllllll}\text { (low) } & 1 & 2 & 3 & 4 & 5 & 6 & 7 & 8 & 9 & \text { (high) Circle one }\end{array}$ 


\section{PROBLEM AREAS}

Indicate for this point in time which of the following are current problems for the child. (Circle response) If you indicate a problem, rate it as to whether the problem is worse or better as a result of time or indlcate no change. For "yes" responses use the following scale:

\begin{tabular}{|c|c|c|c|}
\hline $\begin{array}{c}-2 \\
\text { much } \\
\text { worse }\end{array}$ & $\begin{array}{l}-1 \\
\text { slightly } \\
\text { worse }\end{array}$ & $\begin{array}{l}0 \\
\text { no change }\end{array}$ & $\begin{array}{r}+1 \\
\text { slightly } \\
\text { better }\end{array}$ \\
\hline
\end{tabular}

Indicate which of all those listed are problems for the child. (Circle response).

1. Runaway from home. yes no

2. Physically assaultive to parents. yes no

3. Physically assaultive to younger yes no stblings.

4. Physically assaultive to older yes no siblings or those of same age.

5. Physically assaultive to adult yes no school personnel.

6. Fighting physically with peers yes no at school.

7. Physically assaultive to neighbors, yes no adults, peers, younger children in nelghborhood.

8. Stealing from family members. yes no

9. Theft or vandalism of property yes no within the school.

10. Theft in nelghborhood homes yes no and stores.

11. Verbally antagonistic so as to yes no continually disrupt the family.

12. Virtually no compliance to yes no parental request or limits. 
13. Refusal to accept/perform routine responsibilities at home.

14. Extortion at school from peers. yes no

15. Excessive truancy. yes no

16. Continualiy disruptive to the yes no class at 8 chool.

17. Non-production at school. yes no

18. Sets fires in or near home. yes no

19. Sets fire in the community. yes no

20. Destruction of property in yes no the neighborhood or communtty.

21. Pushing drugs at school or in yes no the comanity.

22. Excesaive use of alcohol.

yes no

23. Uses mar1juana.

yes no

24. Uses hero1n.

yes no

25. Uses other drugs.

yes no

26. Bizzare behavior in community. yes no

27. Social taboos (public sex yes no play, etc.)

28. To what extent is the child currently motivated to change his behavior at home?

$$
\begin{array}{lllllllllll}
\text { (1ow) } & 1 & 2 & 3 & 4 & 5 & 6 & 7 & 8 & 9 & \text { (hIgh) }
\end{array}
$$

29. What is the child's current capacity to change that behavior at home?

$$
\begin{array}{lllllllllll}
\text { (1 ow) } & 1 & 2 & 3 & 4 & 5 & 6 & 7 & 8 & 9 & \text { (high) }
\end{array}
$$

30. To what extent is the child currently motivated to change his behavior at school?
(1 ow)
2
34
5
78
(hIgh) 
31. What is the child's current capacity to change his behavior at school?

$$
\begin{array}{lllllllllll}
\text { (1ow) } & 1 & 2 & 3 & 4 & 5 & 6 & 7 & 8 & 9 & \text { (h/gh) }
\end{array}
$$

32. To what extent is the child currently motivated to change his behavior in the community?

$$
\begin{array}{lllllllllll}
\text { (low) } & 1 & 2 & 3 & 4 & 5 & 6 & 7 & 8 & 9 & \text { (high) }
\end{array}
$$

33. What is the child's current capacity to change his behavior in the community?

$$
\begin{array}{lllllllllll}
\text { (1ow) } & 1 & 2 & 3 & 4 & 5 & 6 & 7 & 8 & 9 & \text { (high) }
\end{array}
$$

